ALESSANDRA ANCONA DE FARIA

\title{
Contar histórias com o jogo teatral
}

Dissertação apresentada ao Departamento de Artes Cênicas da Escola de Comunicações e Artes da Universidade de São Paulo, como exigência parcial para obtenção do Título de Mestre em Artes, sob a orientação da Profa. Dra. Ingrid Dormien Koudela.

São Paulo

2002 
COMISSÃO JULGADORA

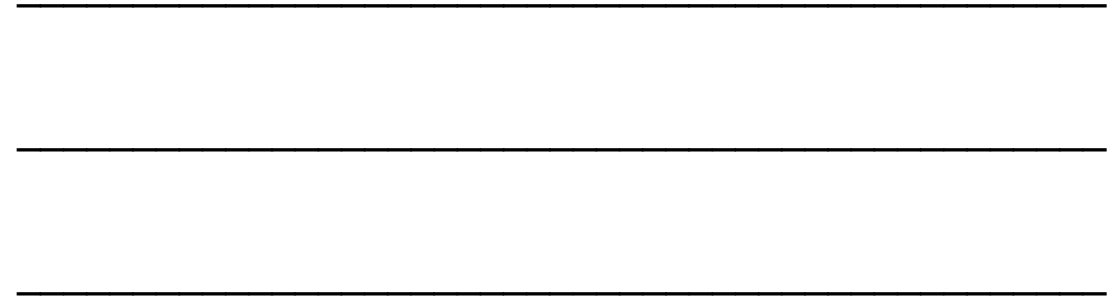




\section{À Nonna, Linda Ancona Lopez, pelas histórias e pelo carinho.}

Aos meus alunos, pela confiança e os olhares de alegria nos momentos de descoberta. 


\title{
Agradecimentos
}

\begin{abstract}
À Profa. Dra. Ingrid Dormien Koudela, orientadora atenta e carinhosa, pela generosidade em comparilhar seus conhecimentos, pelo cuidado com as minhas dúvidas, angústias e reflexões, apresentando-me elementos para que eu não perdesse o foco, o que tornou, elaboração da dissertação, um trabalho alegre.
\end{abstract}

À Profa. Dra. Maria Lúcia de S. B. Pupo, quem coordenou o primeiro jogo teatral do qual participei, pela colaboração fundamental à minha reflexão sobre as relações entre o jogo e o conto.

À Profa. Dra. Terezinha de Azerêdo Rios, pela atenção e receptividade em todos nossos encontros reais e virtuais, e pela grande contribuição na apresentação de novos autores.

À direção e aos funcionários da Escola Alves Cruz por abrir o espaço da escola para esta pesquisa, o que foi fundamental para a sua realização.

A Ana Maria Nogueira, ex-professora e atual colega, pela atenção, apresentando-me para a direção da Escola Alves Cruz .

Aos alunos Daniel, Edmilson, Giovanni, Mariana, Priscila, Sidnéia e Solange, pela disponibilidade em participar do projeto com envolvimento e alegria, tornando este experimento, para mim, um grande aprendizado.

A Regina e a Lia, pelo trabalho de correção minuciosa que fizeram meu texto melhor. Obrigada pelo cuidado nas críticas, lembrando sempre de me dizer sobre tudo de bom que eu tinha escrito. 
Aos funcionários da secretaria do CAC, Anísio, Cida e Robi, que na eficiência e gentileza com que sempre fui atendida, tornaram mais fácil minha vida de mestranda.

Aos meus pais, Cabé e Lia, que sempre me apóiam, seja qual for minha nova criação, fazendo com que eu sinta que sou boa no que faço e muito especial, o que me dá coragem na vida.

Aos meus irmãos, cunhado, cunhadas e sobrinhos, Álvaro, Regis, Bia, Miguel, Lula, Martim, Meni, Luli, Denise, Luiza e Pedro, por estarem por perto sempre que eu preciso, me darem colo e fazerem a minha vida mais cheia, barulhenta e divertida. À minha irmã, Dri, pelas muitas conversas e por ter sabido me dizer na hora certa, qual era a história de amor que me importava contar.

A Telê, tia carinhosa, que esteve sempre interessada no meu trabalho e disposta a me ajudar.

Aos amigos, Adriana, Jaime, Maíta, Dodô, leda, Bruno e Denise, por estarem do meu lado, pela paciência em me ouvir falar sobre os alunos, o objeto de pesquisa, as novidades de cada capítulo... e pelas correções, empréstimos de livros e dicas para o trabalho.

A Rosalba, por me ajudar a encontrar minhas prioridades e meus limites.

Aos meus amigos no ensino de arte: Quim, pelos longos e esclarecedores cafés; Andréa, por estarmos juntas, empurrando e puxando uma à outra; e Ronaldo, que está comigo, bem perto, desde a Santa Marcelina e me ajuda a entender qual é nosso papel na educação. cotidiano.

Ao Du, por fazer com que eu descubra o encanto do conto de fadas, no nosso 


\section{RESUMO}

Esta pesquisa teve como objetivo investigar possíveis relações entre o conto de tradição oral e os jogos teatrais, com a intenção de contribuir para a reflexão de perspectivas do ensino de teatro.

Apoiada na sistematização dos jogos teatrais, proposta por Viola Spolin, investiguei a utilização do jogo em um processo de montagem de uma peça, seguindo o caminho indicado no livro $O$ jogo teatral no livro do diretor.

Para tanto, realizei experimento com um grupo de jovens do Ensino Médio, de uma escola estadual, na cidade de São Paulo, no ano de 2001. Este trabalho foi baseado em pesquisas sobre o conto e o ensino de teatro, bem como na experiência realizada com o grupo de alunos. 


\section{ABSTRACT}

This research intends to check possible relationships between oral traditional short stories and the theatre games, with the intention to contribute to the reflection of perspectives of acting learning.

Based on the theatre games systematization, proposed by Viola Spolin, I did an investigation about the use of games to stage a play, following the instructions of the book The theatre games in the director's book.

For that, I did an experiment with a young group from a state high school in São Paulo city, during the year 2001. This work was based on researches about short stories and acting learning as well with the experiment performed with the young group. 


\section{Sumário}

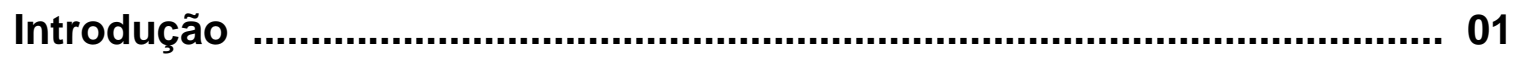

Capítulo 1: Da narrativa ao texto dramático ................................................ 10

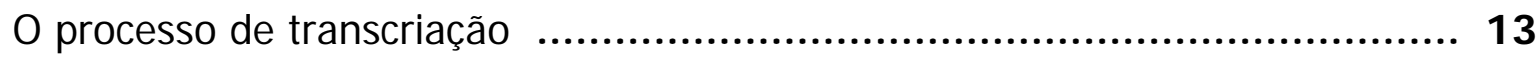

Capítulo 2: Estudo sobre “O jogo teatral no livro do diretor" ................. 47

Preparação ............................................................................................. 52

Oficinas f................................................................................................ 59

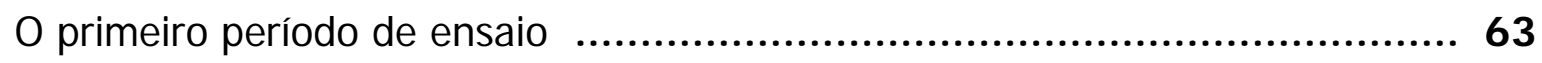

O segundo período de ensaio ................................................................. 74

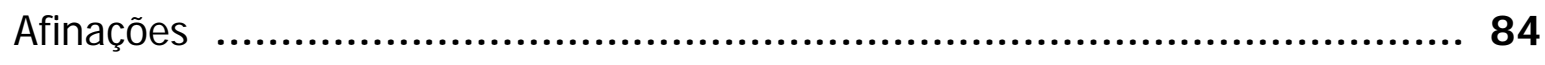

O terceiro período de ensaios .................................................................. 87

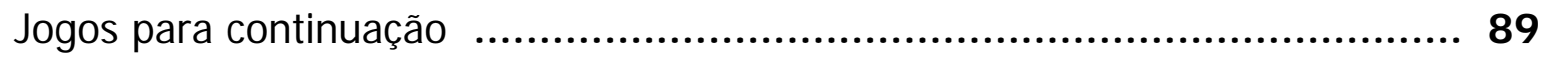

Capítulo 3: O teatro participando da formação escolar ...................... 92

Protocolo ............................................................................................... 98

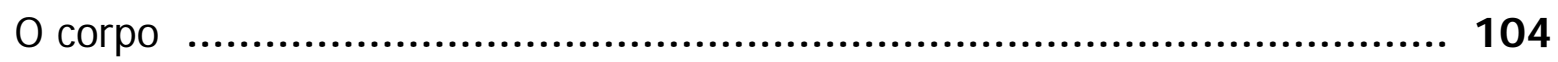

Apresentações

Apêndice 1: O pássaro verde ......................................................... 123

Apêndice 2: Roteiro para o pássaro verde ...................................... 129

Apêndice 3: Texto dramático: 0 pássaro verde................................. 134

Apêndice 4: J ogos para as cenas .................................................. 146

Levantamento Bibliográfico ....................................................... 150 


\section{Sumário de figuras}

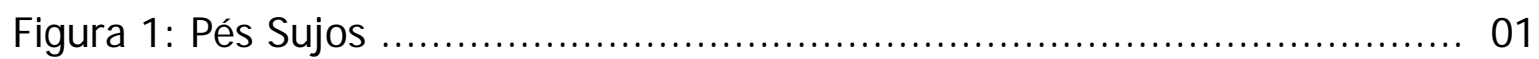

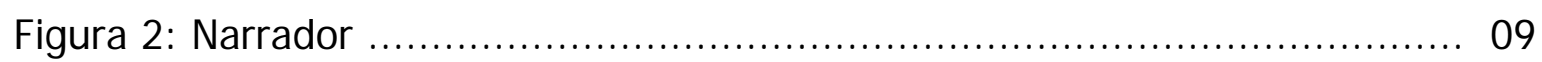

Figura 3: Grupo de teatro Pé Sujo ...................................................... 15

Figura 4: Jogo: 0 que estou comendo? .............................................. 18

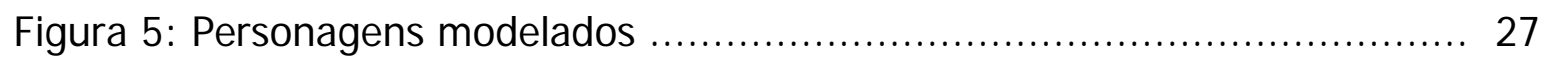

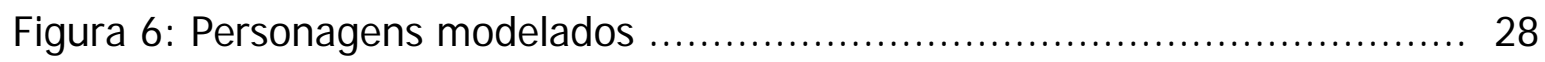

Figura 7: Personagens modelados ................................................... 28

Figura 8: Personagens modelados …................................................. 28

Figura 9: Personagens modelados …................................................ 28

Figura 10: Improvisações da cena do roubo com os personagens do pássaro e da

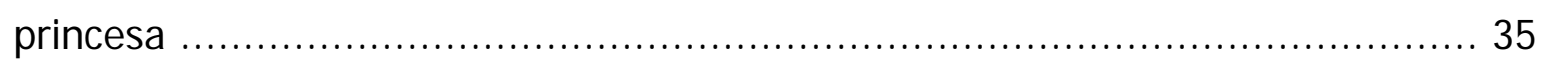

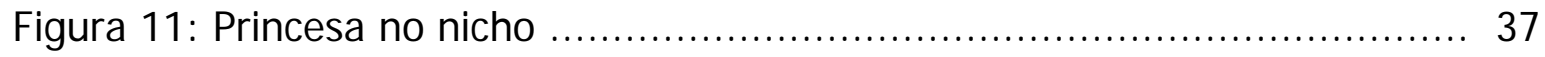

Figura 12: Explorando os cubos ........................................................... 46

Figura 13: Jogo: Dificuldade com pequenos objetos ................................. 61

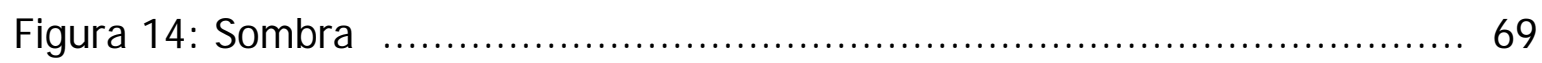

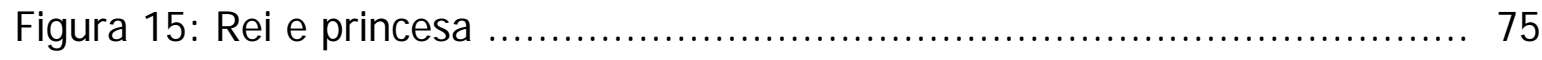

Figura 16: Velório do príncipe ........................................................ 79

Figura 17: Cubos montando a cama da princesa .................................. 80

Figura 18: Cubos montando a janela do príncipe .................................... 80

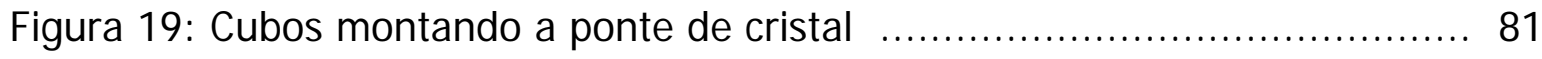

Figura 20: Cubos montando o nicho ................................................ 81

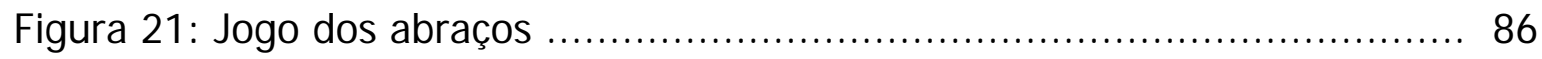

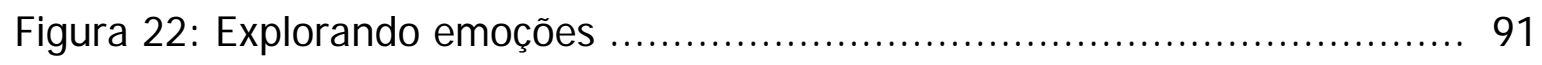

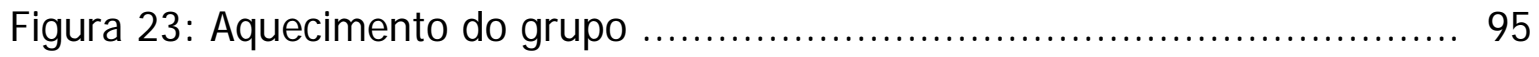

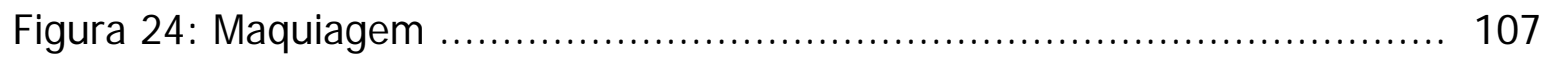




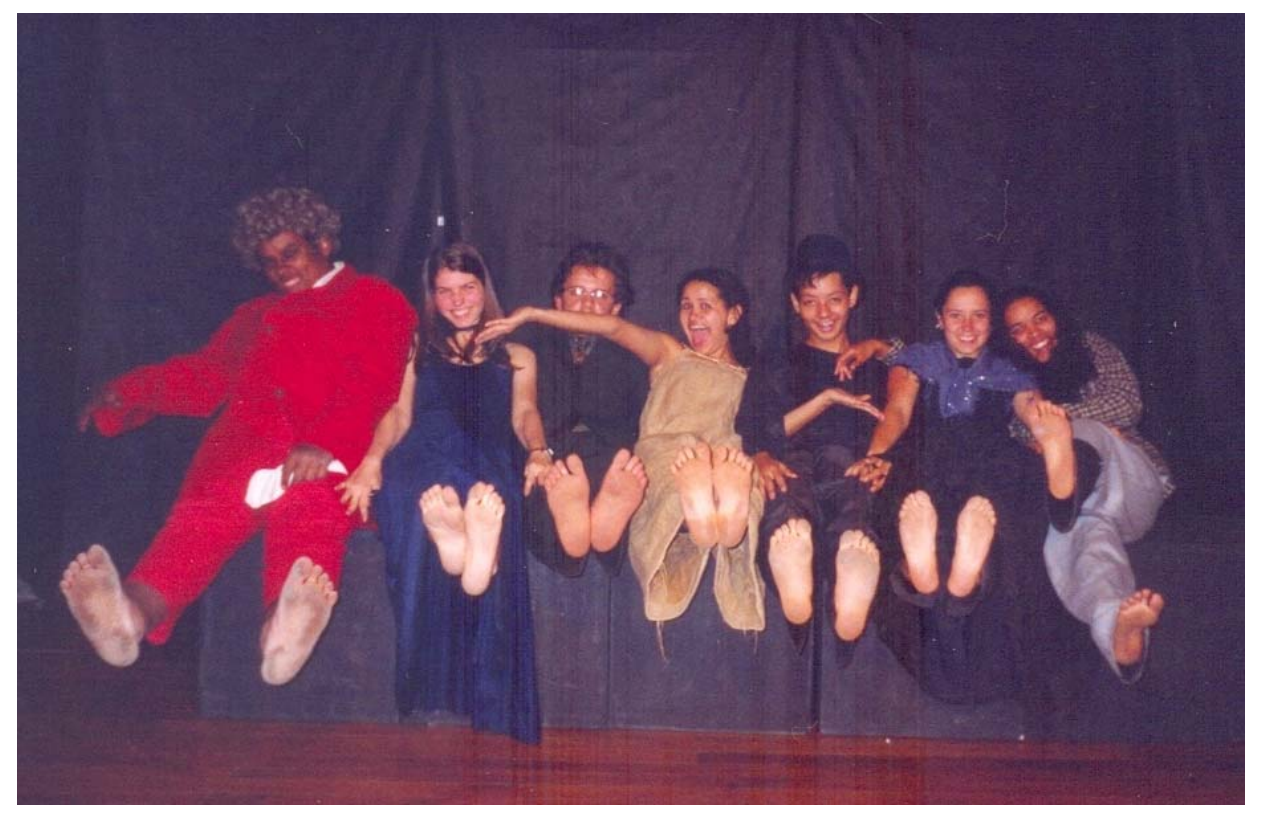

Hora de ir embora quando o corpo quer ficar Toda alma de artista quer partir Arte de deixar algum lugar Quando não se tem pra onde ir Chico Buarque 


\section{INTRODUÇÃO}

Era uma vez um sofá. Seus pares eram duas poltronas e mais alguns móveis espalhados pela sala. A dona do sofá era uma avó que sentava nele para contar histórias. O sofá mudou de sala algumas vezes mas a avó era sempre a mesma e os netos só aumentavam de quantidade e de tamanho, sempre havendo algum por lá, sentado, escutando.

A avó não era chamada de vó, como costumam ser chamadas na intimidade, mas de nonna, o que dá na mesma, apesar de um som tão diferente. Ela tinha nascido no Brasil e passado toda sua vida aqui, mas era filha de uma nonnina que não tinha nascido aqui, mas sim na Itália.

Toda a família que nasceu antes dela, nasceu na Itália e de lá trouxeram as histórias que ela ouviu e contou. Vinham todos de uma cidade chamada Bari ou de cidades vizinhas e cada um trazia alguma coisa consigo. A nonna da minha nonna foi quem pegou as histórias para trazer e aqui distribuir no sofá de sua casa para suas netas.

Com tanta gente italiana na casa, continuaram falando assim, até que eu nasci e minha mãe parou com esse costume. Mas como os costumes não param de uma hora para outra, quando estávamos na casa da minha nonna, a língua falada era uma mistura; dependendo de para quem a pessoa olhava, falava em português ou em italiano. Com isso entendíamos um pouco de cada e as histórias podiam ser contadas misturando as duas línguas.

Assim, acabei guardando na minha caixa de histórias algumas frases em português e outras em italiano, o que me fez saber que o príncipe dizia para a NinaNina "Nina-nina, Nina-nina, te bacerei la bocca la sera e la mattina" e ela respondia "Se minha boca você beijar, tua língua vai secar"! Mas o antes e depois da história, eu lembro em português. 
Os netos começaram a mudar, embora o sofá e a nonna fossem os mesmos e depois que eu tinha completado quinze anos, apareceram crianças pequenas, fazendo com que eu escutasse novamente as histórias.

Desta forma, minha caixa foi se renovando e chegou o dia em que resolvi guardar tudo em uma fita, uma fita de música e não de cabelo, pra tentar escrever e desenhar as histórias. Mas elas não quiseram sair da fita e lá estão até hoje.

Passara-se dezesseis anos e voltei a elas, resolvi que elas fariam parte do que estou escrevendo e voltei para o sofá. A nonna, paciente que é, voltou comigo e me contou tudo outra vez. Anotamos, relembramos, perguntamos para tias e primas sobre os pedaços que cismavam em se esconder e por fim escrevemos três delas inteirinhas, sem nada faltar. Escrevemos, juntas para que elas tivessem a cara daqueles dias de sofá, mesmo sem as frases em italiano, pois quem não tinha sentado lá não poderia entender aquela mistura toda.

Escolhi contar a história do Pássaro Verde ${ }^{1}$. Esta sempre tinha povoado minha cabeça de imagens, cada pedaço da história foi sendo montado dentro de mim nas muitas vezes em que a escutei e remontados quando comecei a contá-la. Devo ter uma enorme coleção de pontes de cristal, de espelhos, de pentes encantados e de momentos em que a pétala de rosa fere o rosto da princesa.

Estas imagens, que se construíram dentro de mim, certamente foram determinantes do modo como vou montando histórias, personagens, ações e cenas na minha vida. Das cenas da vida e deste gosto de ouvir e contar, passei para cenas com jogos, alunos, teatros e escolas. Fiz muitas delas usando o corpo, o gesto, o espaço, a voz; e a vontade de que tudo isso pudesse gerar, nas pessoas que contaram comigo este gosto por contar, imaginar e dar a quem escuta ou vê a enorme porta que a narrativa ou a cena podem abrir.

\footnotetext{
${ }^{1}$ Ver Apêndice 1.
} 
O interesse em trabalhar com contos e a minha experiência com os jogos teatrais no ensino de teatro, me fez decidir por pesquisar em meu mestrado as possíveis relações entre ambos. Desta forma, este trabalho procurou investigar formas de trabalhar a narrativa na experimentação do jogo teatral.

Investiguei a proposta apresentada por Spolin no livro Jogos teatrais no livro do diretor, tanto na sua abrangência teórica, relacionando-o aos demais livros da autora e de outros autores que discutem o tema, como na experimentação com um grupo de alunos.

$\mathrm{Na}$ análise do primeiro capítulo de $\mathrm{O}$ Jogo Teatral no Livro do Diretor (1999), Spolin apresenta alguns aspectos a serem observados quando da preparação da montagem de uma peça teatral. A visão do espaço que o jogo pode ocupar neste processo já havia sido por mim experimentada em anos anteriores, quando utilizei esses mesmos jogos. Conhecer os jogos através da experimentação tanto como jogadora, como coordenadora foi um elemento fundamental para a elaboração desta proposta.

Quanto às técnicas teatrais utilizadas, tive $\mathrm{O}$ cuidado de me manter coerente com a proposta do livro, por ser ele um dos meus objetos de estudo, porém alguns elementos se somaram ao mesmo. A minha experiência com ensino de dança, especificamente com o método Laban $^{2}$ participou de todo o processo de trabalho, seja nos aquecimentos ou relaxamentos, possibilitando um maior domínio corporal e relação de grupo.

O trabalho com Danças Brasileiras $^{3}$ e jogos tradicionais, este último também proposto por Spolin, também fizeram parte de nossa prática. A

\footnotetext{
${ }^{2}$ O Método Laban, proposto por Rudolf Laban é uma proposta de trabalho com o movimento para qualquer pessoa, que irá possibilitar uma ampliação do movimento individual assim como um entendimento de seus componentes. Tem se mostrado um método de trabalho extremamente profícuo no ensino de Dança.

${ }^{3}$ Entende-se por Danças Brasileiras as danças populares existentes nas diversas regiões do Brasil.
} 
recuperação de jogos e brincadeiras de domínio do grupo proporcionou-lhes um enorme prazer e uma alegria contagiante. Foram realizados jogos, propostos ora por mim e ora pelos alunos, que traziam em si a memória de brincadeiras infantis.

Por ser o conto um dos meus objetos de pesquisa, a escolha da peça com que trabalharíamos já estava parcialmente definida por mim quando iniciei o trabalho. A intenção de observar as possibilidades de apropriação do conto através do trabalho com jogos em uma montagem teatral me dava alguns limites no que dizia respeito a troca de material, o que foi um elemento de grande preocupação inicial pois eu não sabia qual seria a recepção do grupo para o texto apresentado.

Exatamente por concordar com Spolin, quando diz que o diretor não faz vôos solos e que o grupo não é o espaço da realização de seus sonhos, estive apreensiva quanto à pertinência de minha proposta para o grupo em questão. Era clara a possibilidade de transformação completa do conto apresentado, no momento em que iniciássemos os jogos, assim como a opção em extrair fragmentos e darmos continuidade ao trabalho apenas com estes. Também me parecia possível a utilização do conto apenas como o gerador de temas que se desenvolveriam independentemente do referencial inicial.

Porém, apesar do temor por estar projetando desejos e interesses meus no grupo, confiei na qualidade do conto e na minha flexibilidade e capacidade de observação do outro, com a qual já havia contado em muitas outras ocasiões.

Entendi que o experimento com um grupo de alunos, com o qual eu pudesse vivenciar as propostas por mim discutidas, seria uma base de enriquecimento para esta discussão. Para tanto, escolhi uma escola pública que abriu a possibilidade da realização de tal experimento. 
Em dezembro de 2000 entrei em contato com a direção da Escola Alves Cruz, com a proposta de desenvolver um curso de teatro extra-curricular, que foi aceita sem nenhuma dificuldade ou discussão sobre a forma pela qual o trabalho seria feito, no que diz respeito à visão de teatro, objetivos teatrais e educacionais e metodologia de trabalho.

Acordamos o horário e período no qual o trabalho seria realizado e a forma de divulgação do mesmo junto aos alunos. A divulgação foi feita por mim, entrando nas salas para convidá-los para o trabalho.

O grupo se formou com os alunos que demonstraram interesse pelo curso e vieram para a inscrição. No primeiro contato conversamos sobre a proposta. Expliquei que o trabalho estava inserido em minha pesquisa de Mestrado e combinamos o funcionamento do grupo no que dizia respeito a horários e freqüência, além de expor a intenção de apresentar uma peça no final do projeto, isto causou muita satisfação nos jovens.

A partir desse momento, o grupo se mostrou muito receptivo e interessado. Foi impressionante $\circ$ valor dado a essa oportunidade. Vários alunos comentaram que, o fato de existir o curso de teatro, era como receber um prêmio. Ficou evidente que o conhecimento possibilitado pela escola não Ihes bastava, sendo necessária a existência de uma atividade que recompensasse o esforço de estudar.

Conversamos sobre suas expectativas e, em grande parte o grupo expressou o desejo de vencer a timidez, de saber se expressar melhor, além da vontade de conhecer teatro.

O grupo de alunos foi composto por estudantes do Ensino Médio, sendo um deles ex-aluno da escola. O grupo teve inicialmente nove integrantes, permanecendo seis até o final da pesquisa. No decorrer do trabalho, foi escolhido um nome, grupo de teatro Pé Sujo. As referências a este grupo serão feitas utilizando esta denominação. 
Os encontros ocorreram no período da tarde, em um horário que possibilitava a participação de alunos do período da manhã e da noite. O espaço disponibilizado para as atividades foi uma sala usada para apresentações, palestras e atividades extracurrículares, que dispunha de um bom espaço livre e um pequeno palco. A iluminação da sala contava, além das luzes gerais, com três spots que podiam ser direcionados para o espaço do palco.

O experimento foi realizado entre os meses de março e novembro, com encontros semanais de três horas de duração, tendo um intervalo de três semanas no mês de julho. A finalização do trabalho ocorreu em novembro, com a apresentação da peça, resultante do processo, para a comunidade escolar, seguida de dois encontros para avaliação.

O trabalho desenvolvido com o grupo de teatro Pé Sujo foi base de reflexão para a temática aqui apresentada. Desta forma, no primeiro e segundo capítulo discuto possibilidades de inserção do conto no ensino de teatro. Para tanto, apresento diversas definições sobre o conto de tradição oral, abordando a importância do narrador como figura de transmissão deste objeto da cultura. A seguir apresento o processo de transcrição da narrativa do conto $O$ pássaro verde para texto dramático, discutindo a importância dos jogos teatrais neste caminho.

No segundo capítulo analiso o livro O jogo teatral no livro do diretor, observando as possíveis relações com o experimento com o grupo de teatro Pé Sujo. Apresento a proposta de Spolin, para a utilização do jogo teatral como elemento para o processo de ensaio de uma peça teatral, discutindo sua inserção dentro do universo escolar. Discuto a maneira pela qual esta proposta foi realizada no presente experimento, refletindo sobre o aprendizado possibilitado neste processo.

No terceiro capítulo discuto a presença do teatro dentro da escola. Abordo a importância desta linguagem artística para a formação humana, discutindo o conceito de felicidade na formação e o papel do afeto para a obtenção de conhecimento. Neste 
capítulo, também foi apresentado a avaliação dentro do aprendizado escolar e o significado atribuído a apresentação no processo vivenciado pelo grupo.

A presente pesquisa, preparada e acompanhada de forma a tornar possível o registro das atividades e, observar e refletir sobre o tema proposto, definiu-se no decorrer dos acontecimentos, das experiências e das reflexões. Foi importantíssimo dialogar com os autores que participaram desta discussão, fato que se verificará com a leitura deste texto.

Espero que esta reflexão possa gerar novas perspectivas para o teatro dentro da escola, enriquecendo a qualidade da formação do cidadão, com a busca de uma sociedade mais justa e feliz. 


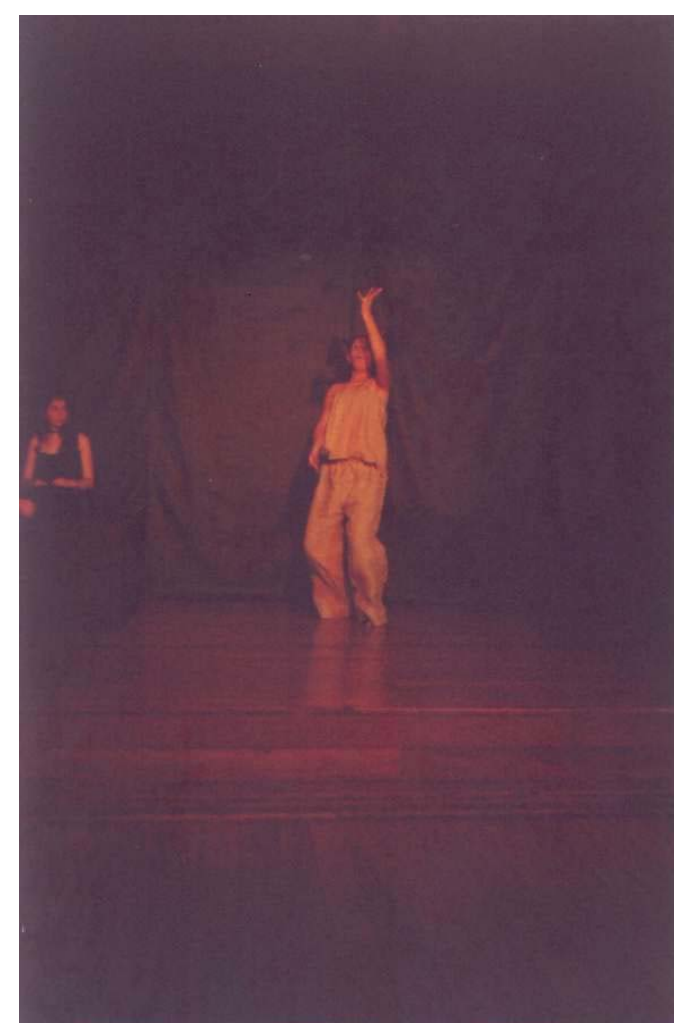

“Agora que o livro terminou, posso dizer que não foi uma alucinação, uma espécie de doença profissional. Tratou-se de uma confirmação de algo que já sabia desde o início, aquela coisa indefinida à qual me referia antes, aquela única convicção que me arrastava para a viagem entre as fábulas. E penso que seja isso: as fábulas são verdadeiras." 


\section{CAPÍTULO 1: Da narrativa ao texto dramático.}

A escolha de trabalhar com um conto de tradição oral partiu da importância em escutar contos no decorrer da minha vida, especialmente na infância. Ter ouvido diversas histórias, me possibilitou a construção de um imaginário povoado por todos estes personagens, lugares e feitos.

Só assim, descobrindo os livros pelos quais terão paixão, os autores que falarão por sua alma, é que os professores irão se sentir apóstolos da literatura, capazes de transmitir aos outros sua boa nova. (Machado, 2001:125)

Fiz uma escolha que falasse à minha alma, com a qual eu me identificasse e que já fosse povoada de imagens e significados dentro de mim.

Além do interesse despertado pela experiência pessoal com os contos, a freqüência com a qual os mesmos são trabalhados dentro das escolas me motivava a esta escolha. Entendo que encontrar novas possibilidades de trabalho a serem desenvolvidas com esta forma narrativa associada ao jogo teatral, pode ser fonte de reflexões para os professores e a qualidade desta associação: conto e teatro.

O estudo sobre o conto de tradição oral é vastíssimo e de grande complexidade. Ao tentarmos identificar as origens de um conto, nos deparamos com diversas coletâneas que, ao que parece, se originam no Oriente com registros espalhados por todo o mundo nos mais diversos períodos da história humana.

Foram feitas várias tentativas de classificação dos contos e a mais citada é a de Aarne-Thompson, que possibilitou a numeração dos contos maravilhosos conforme os tipos. As divisões podem ser apresentadas segundo o tema, os motivos, os enredos, as origens e outras que buscam uma organização deste material tão vasto e em permanente transformação. 
Este método classifica os 2499 motivos em três grandes grupos: contos de animais, estórias populares e gracejos e anedotas, conforme classificação de Antti Aarne. Somou-se a de Stith Thompson, que dividiu os elementos da cultura popular em 24 séries, que correspondem às letras do alfabeto inglês, sendo que cada tema terá um número específico, criando o método Aarne-Thompson, que é utilizado como referência para comparação com outras coleções.

No Brasil temos algumas coletâneas dedicadas ao conto popular brasileiro. Silvio Romero em Folclore brasileiro: contos populares do Brasil (Romero, 1985) evidencia as semelhanças entre as diferentes versões dos contos encontrados em várias regiões do Brasil e do mundo. Esse livro apresenta uma seleção de contos populares do Brasil, classificando-os em contos de origem européia, origem indígena e origem africana e mestiça.

Ele mostra como a estrutura de vários contos se mantém, ainda que seja apresentado com personagens trocados, tais como animais diferentes para narrar uma mesma história, variando evidentemente, de acordo com a característica de cada região onde o conto é narrado.

Câmara Cascudo, em Literatura oral no Brasil (Cascudo, 1998), apresenta algumas das tentativas de classificação dos contos, que irão variar conforme a origem dos mesmos, os ciclos que poderão ser de períodos históricos ou de personagens dos contos, apresentando sua divisão baseada nos gêneros.

A semelhança das narrativas pode ser encontrada nas muitas versões sobre um mesmo conto, o que também se evidência em Contos tradicionais do Brasil (Cascudo, 1986) através das relações estabelecidas entre os contos aqui recolhidos com outras publicações e com a classificação de Aarne- Thompson. ${ }^{4}$

\footnotetext{
${ }^{4}$ Ver anexo 1.
} 
Neste livro, Câmara Cascudo apresenta o conto de tradição oral como um elemento vivo que mostra costumes, idéias e mentalidades da época no qual foi escrito, contado ou criado. As histórias colhidas mantém o vocabulário do contador e é possível evidenciar o trânsito e as interferências dos contos das diferentes regiões e populações do país.

Segundo o autor, que apresenta os contos divididos em 12 seções, estes têm como características: antiguidade, anonimato, divulgação e persistência.

Os motivos dos contos tradicionais são cinco, oito, dez mil, para todo o Mundo. As centenas de milhares que conhecemos e sabemos existir são combinações indefinidas desses motivos essenciais, ambientes, pormenores típicos, situações psicológicas. Os contos variam infinitamente mas os fios são os mesmos. A ciência popular vai dispondo-os diferentemente. E são incontáveis e com a ilusão de originalidade. (Cascudo, 1986:20)

Kátia Canton em E o Príncipe dançou... (Canton, 1994) discute as criações de dança que se basearam em contos de fadas e faz um histórico sobre os mesmos, no qual demonstra que o conto de tradição oral terá muitos versões e não serão necessariamente originárias da oralidade popular, sendo em parte criações dos escritores que os declaravam como recolhidos de contadoras populares.

A apropriação burguesa dos contos populares de magia principiou nos séculos XIV e XV, (...) As narrativas eram então consideradas vulgares e amorais, e foram alteradas e adaptadas para legitimar o status quo e propagar as virtudes de ordem, disciplina, asseio, laboriosidade. (Canton, 1992:32)

A aproximação com o conto também será possível pela abordagem psicológica, que não leva em conta a classificação literária mas sim o seu significado. $\mathrm{Na}$ psicanálise, Bettelheim (1980) analisa o papel do conto de fadas no desenvolvimento infantil, salientando a importância de que os mesmos sejam contados em suas versões mais antigas. Toma como referência o trabalho desenvolvido pelos Grimm e 
propõe que as narrativas escolhidas não excluam a "feiura" das ações e desejos dos personagens.

Von Franz em suas diversas publicações sobre o tema, irá abordar a importância do conto dentro da perspectiva junguiana, relacionando-os com os mitos e ritos e enfatizando a importância em analisar os contos na atualidade.

[As estórias] "podem se desenvolver e ampliar enriquecendo-se através do acréscimo de temas arquetípicos. Se elas são contadas por pessoas dotadas de imaginação e de um talento de contador de histórias elas podem se tornar muito bonitas." (Von Franz, 1981:32)

Neste trabalho não nos deteremos na discussão da importância do conto na estrutura psicológica e tampouco faremos um histórico de sua origem, apesar de reconhecer o fascínio que ambas investigações suscitam. $O$ enfoque dado será da narrativa dentro do processo de aprendizagem teatral e de sua transformação para peça de teatro. Buscaremos mostrar formas pelas quais o conto $O$ pássaro verde, tornou-se uma história muito bonita tanto na primeira narrativa que tive contato, como em sua versão teatral, com o grupo de teatro Pé Sujo.

\section{O PROCESSO DE TRANSCRIÇÃO}

A transformação do conto discutida neste capítulo terá como primeiro momento a narração, o segundo será a exploração do conto escrito, seguido do roteiro de cenas, para se concluir no texto dramático. Cada um destes passos foi intercalado com improvisações que tiveram como base os jogos teatrais.

O conto "O pássaro verde" escolhido para este trabalho tem origem italiana, isto é, a pessoa que me contou, minha avó, ouviu-o de sua avó italiana e, como já foi explicado na introdução deste, eu escutei-o com a mistura destas duas línguas.

Não foi feita nenhuma pesquisa exaustiva para identificação de possíveis transcrições do mesmo, entretanto, pesquisando na edição brasileira de Fábulas 
Italianas (Calvino, 1992) não o encontrei. Na edição italiana, que contém 120 contos a mais que na brasileira, encontrei este conto, com algumas variações na narrativa e intitulado La colomba ladra (Calvino, 1993) ${ }^{5}$. Encontrei duas narrativas que apresentam elementos semelhantes ao conto $O$ Pássaro Verde, sendo uma delas $O$ príncipe-canário, que faz parte da seleção já citada de Calvino (Calvino,1992:73-78) e a outra é O papagaio real que se encontra em Contos tradicionais do Brasil (Cascudo, 1986: 74-76).

Em O papagaio real encontramos a mesma seqüência de ações do príncipe pássaro que se banha em uma bacia d'água, transformando-se em homem. O que faz o príncipe se transformar em pássaro e novamente em homem em O príncipe canário é o folhear de um livro encantado. Nas três histórias o pássaro se aproxima da princesa por uma janela, se transforma repetidas vezes em príncipe e é salvo por alguma ação da princesa.

Calvino em Fábulas italianas (Calvino, 1992) selecionou os contos a partir de outras publicações feitas por pesquisadores das mais variadas regiões da Itália, que percorreram as vilas e cidades recolhendo-os dos contadores.

Nesta seleção, Calvino optou por incluir os contos que melhor expressassem características especificas da narrativa italiana. Dentre as características por ele apresentadas, está a do amor precário, que une dois mundos inconciliáveis, que tem sua prova na ausência; histórias de amantes incognoscíveis, que se encontram de verdade só no momento em que se perdem. (Calvino, 1992: 33/34).

Em sua publicação não fez uma transcrição literal do material selecionado, mesmo porque na maior parte dos contos foi necessária a transposição do dialeto no qual o conto foi registrado para o italiano.

\footnotetext{
${ }^{5}$ Tive acesso a edição italiana de Calvino, apenas após o término do trabalho realizado junto ao grupo de alunos, portanto, não houve qualquer interferência na redação do conto.
} 
O papel do contador de histórias é extremamente importante dentro da discussão sobre a escolha da utilização de um conto de tradição oral. Segundo a professora Maria Lúcia S. B. Pupo:

Benjamin nos lembra que a desvalorização da experiência transmitida oralmente é que acabou acarretando que o narrador se deslocasse do domínio da palavra viva e passasse a se confinar no campo da literatura. Se as marcas do discurso do contador têm uma multiplicidade de linguagens como referência, as do narrador são exclusivamente lingüísticas. (Pupo, 1997:24)

Tendo este entendimento da importância do papel do narrador, optei por contar ao invés de ler o conto. Esta opção se deveu inicialmente por achar uma perda significativa abrir mão deste momento da narrativa. Ter experimentado o contato com os contos através da narrativa dos mesmos já seria razão suficiente para esta escolha, e as muitas pesquisas que apontam a importância do narrador dentro do processo de conhecimento do conto só vieram reforçar esta opção. Desta forma, o trabalho com o conto iniciou-se através da sua narrativa,feita por mim para o grupo. Abaixo vemos o grupo de alunos que participou de todo o processo de trabalho ${ }^{6}$.

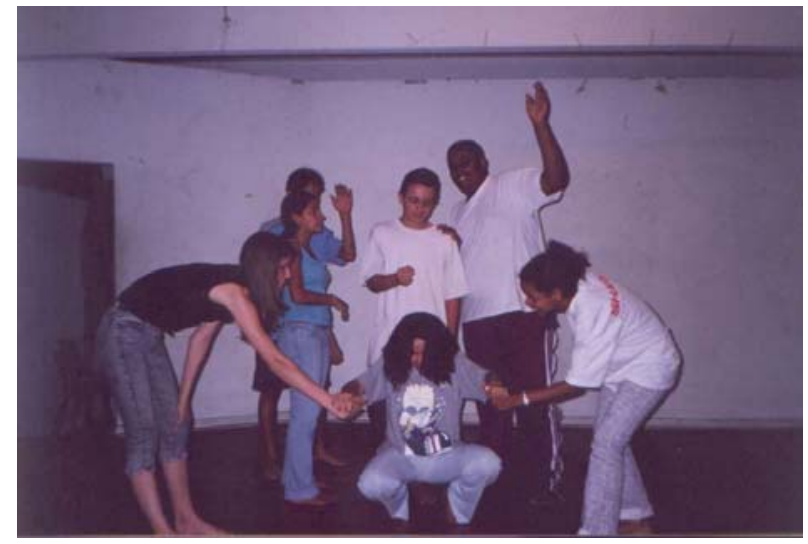

Figura 2: Grupo de teatro Pé Sujo.

\footnotetext{
${ }^{6}$ Todo o grupo de alunos permitiu a utilização de seus nomes e das imagens registradas durante todo o processo.
} 
E para nós aí está a sua [do conto] verdadeira moral: à falta de liberdade da tradição popular, a essa lei não escrita pela qual só se concede ao povo repetir motivos ruminados, sem "criação" verdadeira, o narrador responde com uma espécie de esperteza instintiva: talvez ele próprio acredite fazer apenas variações sobre um tema; mas na realidade acaba por falar-nos daquilo que Ihe vai no coração. (Calvino, 1992).

A narrativa oral me pareceu a única opção para que eu pudesse falar sobre o que me ia ao coração. Apesar desta história já ter um espaço significativo dentro de mim, e da minha experiência se dar tanto ouvindo como contando-a, trabalhei por um período na elaboração desta forma de contar antes de contá-la ao grupo.

A elaboração da narração foi feita tanto no processo de transcrição da mesma, como pela narrativa para diversas pessoas. Estas narrativas me permitiram um maior domínio do meu gestual para cada momento narrado. Sem que fosse determinada por mim nenhuma gestualidade, pude observar algumas repetições que se deram tanto no gesto como na escolha das palavras. O ritmo da narrativa foi o que mais pude explorar e transformar através destas várias narrações que antecederam o trabalho com o grupo, pois pude observar as reações em cada uma delas e descobrir novos ritmos para cada momento do conto. Como explicita Pupo:

O contador é visto como produtor de uma narrativa oral teatralizada; ele cria entre si mesmo e os múltiplos personagens que traz à tona, uma relação de exterioridade, senão de estranheza. Seu papel é o de trazer ao público a palavra de um outro. O fato de ser uma testemunha que não se identifica com os personagens mostrados, no entanto, não o condena irremediavelmente a um estilo "neutro" ou "objetivo". Ele manifesta suas simpatias, faz comparações, tece conjecturas e assim por diante. (Pupo, 1997:33)

A apropriação do conto através do ato de contar se tornou evidente para mim tanto na forma narrativa quanto nos múltiplos significados que a mesma já havia obtido através do estudo desenvolvido com o conto.

Ao contá-lo para o grupo de alunos, pudemos observar os significados que cada um dos participantes atribuiu à narrativa neste primeiro contato com a mesma. 
Pedi que cada aluno escrevesse suas primeiras impressões do conto e escolhesse uma comida e um objeto que o simbolizassem. $O$ registro escrito das impressões causadas pela escuta do conto possibilitou, em um primeiro momento, a reflexão individual ocasionada pela escuta do conto. Este material se mostrava necessário não apenas para um contato inicial, individualizado, com a narrativa, como para a presente pesquisa poder observar no final do processo as mudanças ocorridas quanto ao significado do conto para cada participante.

A comida e o objeto escolhido seriam apresentados através dos jogos $O$ que estou comendo e Dificuldade com pequenos objetos ${ }^{7}$, (como podemos observar na figura 3, pág.16) Os alunos anotaram suas impressões nos seguintes comentários:

A minha impressão da história é que é um conto de fadas como todos os outros que eu conheço, porém este contém situações que eu jamais ouvi num conto de fadas, como construir um palácio e complicar o encontro só pra se vingar da mágoa passada. COMIDA: Sopa, OBJETO:Espelho. Solange

Eu tive a impressão que se você ama alguém de verdade, você não pode reparar na aparência como o príncipe fez, deve é amar mais e mais pois ela sofreu pela amor dele e ele acabou a deixando só. Isso serve de lição para que ame e seja amado pois isso vale a pena. COMIDA: Nhoque, OBJETO: Espelho. Edmilson

É super interessante como a princesa ficou pelo príncipe como foi capaz de ficar 6 meses a pão e água por algum que nem tinha certeza que amava. $O$ príncipe foi muito ignorante ao ver a princesa daquela maneira. Ela resolveu dar o troco de tudo que passou e valeu a pena porque ele se arrependeu. COMIDA: Macarrão, OBJETO: Garrafa de Vinho. Sidnéia

Percebi na história que a princesa ao passar por tudo que passou pelo príncipe, quis Ihe "dar o troco", ou seja, mesmo o amando ela quis que ele sofra por ela, assim como ela sofreu, e ame como ela amou ou ama. COMIDA: Macarronada, OBJETO: Espelho. Mariana

\footnotetext{
${ }^{7}$ Todos os jogos citados são propostos por Viola Spolin. Explicarei cada um deles de forma resumida para que seja compreensível para o leitor o que foi realizado junto ao grupo. No jogo $\mathrm{O}$ que estou comendo, o jogador deve deixar clara a comida escolhida pelo ato de "comê-la". Em Dificuldade com pequenos objetos, o jogador deve manipular um objeto que apresente dificuldade para a manipulação, tal como retirar uma tampa emperrada ou abrir um zíper emperrado.
} 
Essa história me trouxe a impressão de amor e ódio além de uma bela vingadinha. COMIDA: Pavê, OBJETO: Faca de dois gumes. Giovanni

As impressões que me deixou o texto foi de que nós somos como o príncipe e precisamos de uma princesa para nos ensinar, que o perdão traz a felicidade. COMIDA: Macarronada, OBJETO: Caderno. Daniel ${ }^{8}$

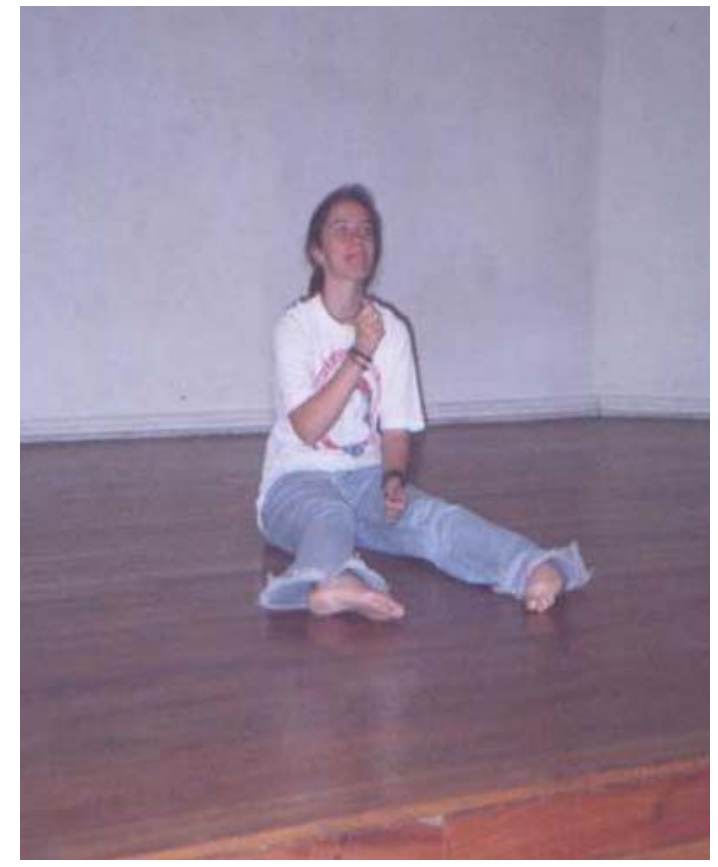

Figura 3: Jogo O que estou comendo?

Nos comentários trazidos pelos alunos, observamos a atenção dada ao tema da vingança e da traição. Discutimos as impressões de cada um e ficou evidente o incomodo que causou a atitude do príncipe. As escolhas das comidas se deveu em parte ao prazer na escuta do conto, boa parte dos alunos relatou escolher uma comida que gosta, pois a situação de escuta foi extremamente prazerosa. Estas impressões reforçam a visão da importância do narrador e do contato com o conto pela escuta.

\footnotetext{
${ }^{8}$ Os textos dos alunos reproduzidos neste trabalho não sofreram interferências de minha parte, exceto quando o erro gramatical impediu a compreensão do mesmo. Esta opção se deve ao fato de considerar importante a explicitação da forma escrita escolhida pelos alunos, não apenas por podermos identificar o domínio da língua, mas também pelos códigos lingüísticos que este grupo possui.
} 
A escolha do pavê, feita pelo Giovani, deveu-se à associação com a vingança, pois "a vingança é um prato que se come frio", assim como o pavê. Na escolha dos objetos, o espelho foi o elemento mais marcante. O tema das relações amorosas é fundamental para o adolescente, o que pode ser confirmado no aspecto mais enfocado pelo grupo.

Em meu trabalho como professora de teatro, observei a freqüência com a qual este tema é escolhido para os jogos ou montagens realizadas. O fato de ser um período da vida no qual boa parte dos alunos inicia sua experiência amorosa é marcante para que este interesse seja revelado.

Após este primeiro contato com o conto através da narrativa, seguimos a investigação tendo como base o conto transcrito ${ }^{9}$.

A pesquisadora Linei Hirsh em sua dissertação Transcrição teatral: da narrativa literária ao palco discute o processo de transformação da narrativa literária para texto dramático. Apresenta a opção do termo transcrição em substituição à adaptação já que transcrição contém as idéias de transcodificação e de criação (Hirsch, 1988).

A escolha de um termo que una os conceitos de transcodificação e de criação, se deve ao entendimento de que a obra teatral que partiu de uma outra obra de origem é aquela que percebe "o ponto de chegada" como resultado de uma criação teatral verdadeira, sem amarras à obra que lhe deu origem, sem o "ranço" de certos espetáculos que procuram ajustar, acomodar, amoldar. (Hirsch, 1988:24).

Neste mesmo estudo, Hirsch apresenta os principais procedimentos que ocorrem na transcrição teatral, considerando que os mesmos não abrangem a totalidade das opções utilizadas. São eles: eliminação, condensação, ampliação,

\footnotetext{
${ }^{9}$ A escrita do conto foi feita, inicialmente, por mim à partir das anotações realizadas com a narração de minha avó. A versão apresentada no apêndice 1 é resultado de diversos momentos de elaboração para que fosse possível encontrar uma forma escrita que traduzisse a intenção presente no conto narrado, buscando, entretanto, uma formalização pertinente à escrita e não mais a narrativa oral.
} 
associação e fragmentação. No decorrer deste trabalho demonstrarei a utilização destes procedimentos.

Fazendo um paralelo com a situação escolar, no meu trabalho como professora de teatro, fiz diversas transcriações de textos com os quais trabalhei. As razões que me levaram a transformar um texto para o trabalho com os alunos variaram de acorde com o grupo e o texto, mas podemos levantar alguns aspectos comuns.

Os motivos que se repetem nas várias situações escolares são o número de personagens em contraste com o número de alunos/atores e a extensão do texto. $\mathrm{Na}$ grande maioria dos grupos com os quais trabalhei, são menos os personagens do que os atores, o que provoca a necessidade de desdobramento de personagens ou criação de novos que se adeqüem a estrutura dramática.

Outro problema presente em boa parte dos textos é o desequilíbrio entre os personagens, quanto à importância de cada um na peça. Este desequilíbrio, de maneira geral necessário para o desenvolvimento da trama, ocasiona um número excessivo de falas e presença nas cenas para uns poucos personagens, se comparados com o todo da peça.

Esta questão é bastante conflitante dentro do grupo já que o interesse dos alunos, embora não seja homogêneo, é semelhante; já, a freqüência da presença em cena dos personagens é, de maneira geral, desequilibrada, sendo necessário, muitas vezes, uma transcriação que atenda também a este interesse. Sem a adequação, corre-se o risco de desaparecer o interesse dos alunos ou ser criada a visão de existirem alunos mais aptos ou mais importantes que outros. ${ }^{10}$

O outro aspecto apontado, o tamanho dos textos, também é freqüentemente um fator determinante para a necessidade de adaptação. Para que fosse possível

${ }^{10}$ Voltaremos a abordar esta questão mais adiante quando falarmos do trabalho dos jogos e das soluções encontradas com o grupo Pé Sujo. 
trabalhar um texto longo em uma montagem escolar, seria necessário um tempo muito superior ao que é dado para o professor nas aulas de Arte. Evidentemente não é possível trabalhar em uma mesma montagem mais do que um ano letivo, pois o interesse do grupo desaparece no meio das férias escolares. Dessa forma, quase sempre são necessários cortes de cenas ou de falas para que a montagem se viabilize sem que o interesse do grupo desapareça.

A complexidade da linguagem utilizada também é um fator a ser observado, pois muitas vezes, o entendimento da história se perde devido a este fator. Ao optarmos pela manutenção da linguagem, nos deparamos com a necessidade de aprofundar o período dedicado à compreensão do texto. Este aspecto irá influenciar diretamente a forma do texto ser dito em cena.

Fazer escolhas para a adaptação de um texto seja ele dramático ou não, é bastante complexo, para não dizer sofrido. A principal dificuldade é saber o que retirar. O que é essencial no texto? Qual fala ou cena não é fundamental para a manutenção da estrutura narrada? Como saber se estou mantendo a poesia do texto com os cortes propostos?

Responder a todas estas questões é muito difícil e foi exatamente para ter um auxílio nestas respostas que nos utilizamos do trabalho de Propp (1984), no processo com O Pássaro Verde. Ao esclarecer os passos fundamentais para a estrutura de um conto e ter maior clareza da importância dos personagens, foi mais fácil fazer a transcriação.

O estudo morfológico apresentado por Propp nos permitiu um entendimento do conto, de sua estrutura e de seus personagens, sendo uma base de reflexão para as propostas desenvolvidas com o grupo de alunos no processo de jogos teatrais com o conto e na escrita da transcriação do mesmo para teatro. 
Em seu estudo sobre o conto maravilhoso, Propp (1984) apresenta uma base morfológica dos contos de magia, um estudo das formas do conto, estabelecendo leis que regem a sua disposição, à partir das funções dos personagens.

Propp entende como função o procedimento de um personagem, definido do ponto de vista de sua importância para o desenrolar da ação. Entendendo que os contos seguem uma seqüência de funções semelhantes, irá organizar a sua estrutura de acordo com as mesmas. Nesta organização, vemos uma primeira seqüência de funções denominadas como situação inicial, designado pela letra $\alpha$. A elas se seguem 24 funções que serão designadas pelas letras do alfabeto, de $A$ à $W$, tendo, em muitos casos, desdobramentos para cada uma delas.

Segundo Propp, podemos resumir a estrutura dramática do conto $O$ pássaro verde, da seguinte forma:

Situação Inicial: Princesa completa 15 anos e ganha um espelho de seu pai.

Dano (A): Os três presentes recebidos por seu aniversário são roubados pelo pássaro verde. Observamos que o roubo ocorre três vezes, o que não significa uma nova função mas apenas um elemento de triplicação da mesma função, que somados terminam por caracteriza-la (Propp, 1984:67/68).

Carência (a): A princesa adoece de tristeza.

Mediação (B): A princesa toma conhecimento do pássaro-príncipe por intermédio do menino tonto.

Primeira função do doador (D): Princesa permanece sete anos no nicho. ${ }^{11}$

Reação do herói (E): Princesa é rejeitada e abandonada pelo príncipe.

Fornecimento e recepção do meio mágico (F): Princesa recebe a bolsa cheia de moedas de ouro.

Tarefa difícil (M): Príncipe tenta casar com a princesa, pedindo-lhe a mão em casamento, construindo a ponte de cristal e passando-se por morto.

\footnotetext{
${ }^{11}$ Embora entenda a velha como doador, a definição de Propp para a primeira função do doador, esclarece a razão de haver colocado a ação da princesa para esta função: O herói é submetido a uma prova; um questionário; a um ataque; etc, que o preparam para receber um meio ou um auxiliar mágico. (Propp, 1984:41)
} 
Reconhecimento (Q): Príncipe reconhece a princesa.

Casamento (W): Príncipe e princesa se casam.

Neste mesmo estudo, Propp distribuirá as funções entre os personagens, agrupando-as em esferas da ação, que são de: Antagonista, Doador, Auxiliar, Princesa e Seu Pai, Mandante, Herói e Falso Herói. Para definirmos quais personagens se encontram em cada uma das esferas devemos considerar que a distribuição dos personagens nas esferas poderá se dar de três maneiras. Na primeira a esfera de ação corresponde exatamente ao personagem, na segunda um personagem ocupa várias esferas de ação e na terceira, uma única esfera de ação se divide entre vários personagens (Propp, 1984:73-75).

Antes da realização da transcriação do conto O Pássaro Verde para teatro, fiz a análise dos personagens presentes no conto conforme as esferas de ação proposta por Propp.

Ao definir o personagem que ocupa a esfera de ação do HERÓl, nos deparamos com uma característica bastante atípica dentro dos contos, já que o herói neste conto é a princesa. É ela quem parte para realizar a procura, quem reage às exigências do doador e que termina a sua busca com o casamento. É um herói-vítma, já que também é ela quem sofre o dano e a carência.

Canton (1984) demonstra a forma pela qual as transcrições dos contos de fadas feitas no séc. XVIII, especialmente por Charles Perrault, irão pregar uma moral da mulher submissa, frágil, com padrões a serem seguidos. No Pássaro Verde nos deparamos com uma visão da mulher bastante diferenciada, já que é ela quem assume as ações determinantes para o desenrolar da história.

A esfera de ação do ANTAGONISTA será ocupada pelo príncipe, que além de antagonista também é o objeto de desejo do herói, transformando-se do pássaro que causa o dano e a carência na princesa, em príncipe que a ama, a despreza e volta a amá-la, terminando por casar-se com ela. 
A esfera de ação do DOADOR é ocupada pela velha que dá para a princesa o objeto mágico (bolsa) e faz com que ela volte a ficar bonita e saudável.

A esfera de ação do AUXILIAR é ocupada por dois personagens, sendo primeiro o menino tonto que descobre o pássaro verde e conta toda a história para a princesa, levando-a ao local onde ela poderá encontrar o príncipe-pássaro; e o segundo, a bolsa mágica que possibilita à princesa a construção do palácio e nele viver.

A esfera de ação da PRINCESA e SEU PAI é ocupada inicialmente pela própria princesa e o rei, seu pai e, posteriormente, pelo príncipe, já que ele é o personagem procurado.

A esfera de ação do MANDANTE é ocupada pelo rei, pai da princesa, já que ele é quem anuncia a necessidade de alguém que possa divertir a princesa, fazendo com que a carência estabelecida pelos roubos dos presentes deixe de existir. O rei, entretanto, não envia nenhum herói em busca dos objetos roubados; neste sentido, a princesa, visto que é o herói, se coloca em movimento e sai em busca de seu objeto de desejo: o príncipe que a ama.

Não identificamos nenhum personagem que se coloque na esfera de ação do FALSO HERÓI.

Entretanto, apesar do auxilio importantíssimo de Propp, foram os jogos teatrais que possibilitaram a forma criada junto ao grupo Pé Sujo. Nas improvisações realizadas construímos e reconstruímos o conto. Estabeleço um paralelo com o entendimento proposto por Machado sobre Penélope:

...o que acontece é que ela está experimentando criar sua própria história no tear, de cada vez tecendo uma coisa diferente, ensaiando, fazendo várias versões, re-tecendo, re-escrevendo, porque é uma história que nunca tinha sido escrita antes. A história de uma mulher que tem uma escolha. (Machado, 2001:40) 
Através do jogo teatral foi possível experimentar o nosso entendimento sobre o conto e escolher qual história queríamos contar, quais as formas teatrais e como estruturaríamos o texto dramático.

Após o primeiro contato com o conto pela narrativa, começamos a trabalhar com o texto ${ }^{12}$ através de jogos teatrais que levassem à compreensão e verbalização do mesmo. Já havíamos explorado o conto tendo como referência a narrativa e passamos, então, para o segundo momento, quando o grupo tinha a narrativa escrita nas mãos.

A exploração do texto escrito possibilitou a multiplicidade de entendimento da história e um domínio da mesma que deu liberdade para os participantes poderem se desprender da necessidade do papel para ter claro a estrutura narrada.

Demos inicio, então, a uma aproximação ao conto partindo das ações, espaços e personagens presentes, o O que, Onde e Quem, propostos como estrutura dramática do jogo teatral, por Spolin (1987). Realizamos o jogo Siga o Seguidor ${ }^{13}$ de forma que as ações propostas fossem narrando o conto.

As ações escolhidas foram: olhar no espelho, chorar, colocar a fita no cabelo, se ferir com a pétala, sofrer (príncipe doente), tirar o véu, reconhecer, pedir perdão, se entender e comer docinhos. Como pode ser observado, as quatro primeiras ações estavam ligadas à princesa, a quinta ao príncipe, a sexta, a princesa, a sétima e oitava ao príncipe e as duas últimas aos dois. Continuamos o trabalho com jogos que explorassem as ações presentes no conto e fizemos uma lista de todas as ações que ocorriam no decorrer da narrativa.

Neste primeiro momento de exploração das ações, houve um salto significativo da narrativa, já que após a escolha da ação de colocar a fita no cabelo, o jogador

\footnotetext{
${ }^{12}$ Ver apêndice 1.

${ }^{13}$ Este é um dos jogos propostos por Viola Spolin, onde uma pessoa propõe uma ação que deverá ser seguida pelos demais jogadores, a troca do proponente se dá sem nenhuma interferência do coordenador e sem nenhuma combinação prévia dos jogadores. Todos irão propor e seguir.
} 
seguinte escolheu como ação se ferir com a pétala, excluindo dessa forma todo o sofrimento da princesa, a descoberta do príncipe, o período passado no nicho e o primeiro pedido de casamento.

Esta exclusão gerou uma enorme surpresa no grupo, porém a regra do jogo estabelecia que não era possível retornar na descrição linear da narrativa, foi dada a continuidade com toda esta lacuna, o que foi devidamente comentado na avaliação.

Depois de trabalhar com as ações presentes, exploramos os espaços. O primeiro jogo que exploramos o espaço foi o jogo do Onde $1^{14}$. Os espaços escolhidos foram: a Ponte de cristal e o Quarto do príncipe. Neste primeiro jogo com o espaço, nenhum deles deveria assumir nenhum personagem do conto, o que resultou em ações completamente diferentes das narradas.

Observamos quais os espaços da narrativa que haviam aparecido no jogo e elencamos todos os demais, sendo:

- Quarto da princesa (no palácio de seu pai);

- Sala do palácio do pai da princesa;

- Floresta;

- Quarto do príncipe;

- Nicho;

- Rua do reino do príncipe;

- Construção;

- Sala do palácio do príncipe;

- Sala do palácio da princesa;

- Ponte de cristal;

- Igreja;

- Salão de festa do palácio do príncipe.

\footnotetext{
${ }^{14}$ No jogo do onde, os jogadores devem escolher um espaço, desenhá-lo e improvisar nele. Este desenho deverá ficar visível para que os jogadores possam recorrer a ele sempre que se esqueçam da disposição do local definido pelo grupo.
} 
Ao colocar os espaços em ordem de aparecimento no conto, percebemos que alguns deles se repetiam várias vezes e desenhamos um cenário para cada espaço:

O próximo enfoque dado foi ao Quem, através da exploração dos personagens do conto. Exploramos a modelagem de cada um deles: dois jogadores deveriam modelar um terceiro, caracterizando-o como um dos personagens do conto. Após a caracterização, que incluía o gesto do personagem, a platéia deveria identificá-lo. Fizemos este jogo até que todos os participantes tivessem sido modelados. As caracterizações foram muito interessantes, apesar da falta de recursos, já que utilizamos somente materiais e roupas que eles estavam vestidos.

No momento que a platéia identificava o personagem, ela também definia as características do mesmo, como pode ser observado nas figuras $4,5,6,7$ e 8 , seguintes.

Os personagens modelados foram:

VELHA de hoje em dia;

REI dos Sem Terras;

MENINO de rua, pobre;

RAINHA snob, com a época indefinida;

PÁSSARO gay e feio;

PRINCESA descolada, de hoje em dia.

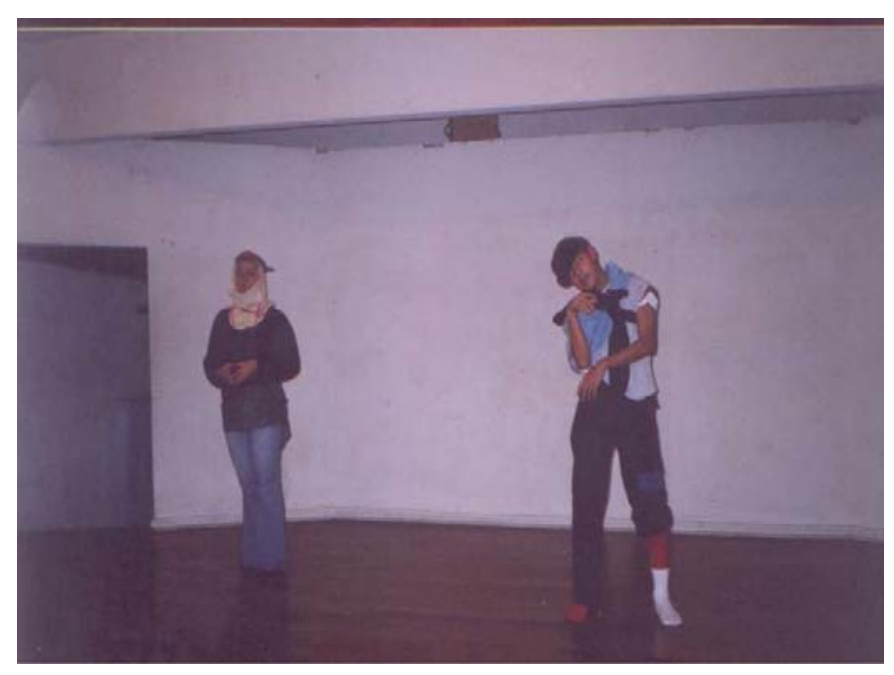



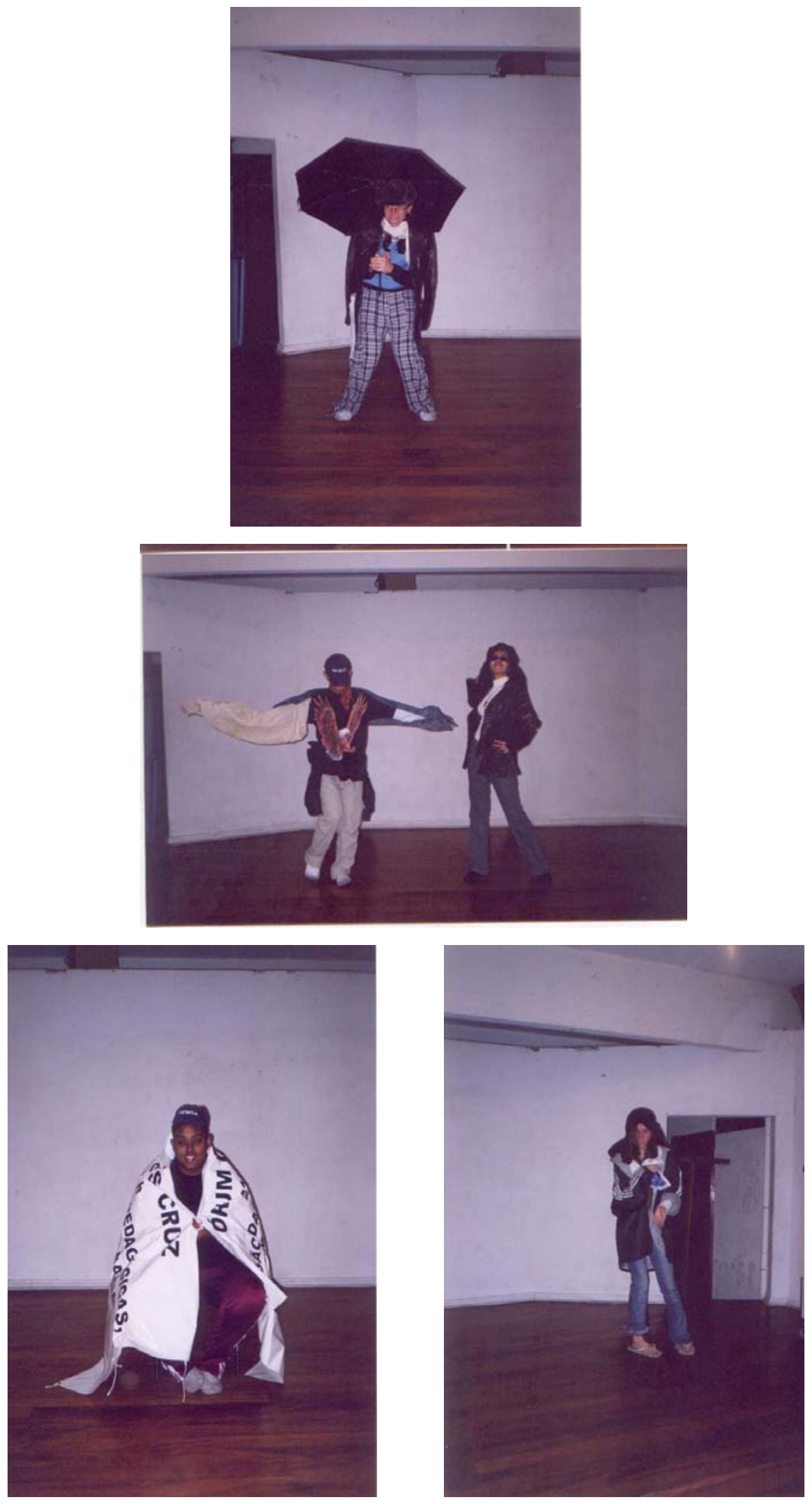

Figuras 4, 5, 6, 7 e 8: Personagens modelados 
As definições de quais características teriam cada um dos personagens denota a aproximação estabelecida entre o conto e o cotidiano dos alunos. Na caracterização observamos diversos elementos do universo do grupo, além do questionamento de estereótipos presentes para cada um destes personagens.

A generalização dos personagens apresentados no conto possibilita uma aproximação com o universo de cada aluno, conforme nos explicita Pupo:

Os contos maravilhosos têm como característica fundamental o fato de transportarem de imediato o leitor a um universo completamente diferente do nosso, tanto no nível dos seus seres, quanto das leis que o regem, sem que isto constitua, no entanto, um objeto de surpresa. O leitor se depara com uma indeterminação completa em termos espaciais e temporais.

Seus heróis não são individualizados; tem uma função ou um nome, mas não possuem sobrenome, por exemplo. São caracterizados de modo física e moralmente genéricos; não são retratados, mas esboçados. (Pupo, 1997:41)

Essa liberdade de caracterização que o conto apresenta pode gerar através do jogo a multiplicidade de soluções para as características de cada personagem.

Pela manutenção de algumas características, nas soluções dadas pelos filmes e ilustrações dos contos de fadas, poderíamos nos deparar com a simples repetição destas versões. Entretanto, a experimentação realizada através dos jogos já havia criado no grupo condições de extrapolar às soluções estereotipadas, podendo estabelecer um significado particular à este grupo.

Por exemplo, a adaptação da linguagem referente ao personagem do menino tonto foi tão forte, que permaneceu como marca até o momento da apresentação da peça. Também foi responsável pela escolha das falas deste personagem: Cara, que maluquice é essa? Olha só! Mas como é que essa lenha ta subindo aí sozinha? Ei! Tem alguém aí? Não tem não! ou Combinado realeza! O uso de gírias e expressões utilizadas por adolescentes se deveu a caracterização resultante do jogo. 
Com a realização dos jogos que exploraram a ação, o espaço e os personagens do conto, cada um dos alunos contou novamente o conto, com a perspectiva de um dos personagens. Pupo explica a relação estabelecida entre o narrador e os aspectos presentes em sua atuação:

Quando se expõe fisicamente diante do público, o jogador-narrador se defronta com todas as questões de atuação teatral; seu corpo passa a significar, tanto quanto significam os corpos dos jogadores-personagens. As variações de seu olhar, sua movimentação, a qualidade da concentração, a diversidade da emissão vocal, não podem deixar de ser lidos e interpretados pela platéia. (Pupo,1997:87)

Para que cada um pudesse narrar o conto sob o ponto de vista de um dos personagens, foi necessário assumir não apenas a visão daquele personagem como também a gestualidade e a linguagem. Essa forma de narrar possibilitou a exploração do conto sob vários pontos de vista, dos vários personagens e, também, de como cada um dos alunos estava vivenciando o conto até aquele momento.

Ao serem questionados sobre as mudanças na própria visão sobre o Conto de Fadas, deram as seguintes respostas ${ }^{15}$ :

Sim, e muito, antes eu pensava nas princesas sofredoras com as madrastas e com esse conto vi uma bem diferente. Mariana

Sim pois você esta compondo esse conto e se torna parte de você. Edmilson

Mudou. Achei eles bem mais legais. Agradáveis e interessantes. Priscila

Mudou, pois eu vi que representar um conto exige muito mais do apenas ver. Daniel

Com certeza, hoje eu tenho outra visão sobre os contos, e o que eu mais fiquei surpresa foi da diversidade que ele oferece para o teatro. Solange

\footnotetext{
${ }^{15}$ No final de todo o processo de trabalho, realizamos uma avaliação também composta de um questionário - Anexo 4. Dentre as perguntas, foi feita esta que deu origem às respostas apresentadas: A tua visão sobre o conto de fadas mudou com esse trabalho?
} 
Trabalhar com o conto foi legal, pois foi o primeiro texto com que trabalhei e coisas do gênero, nesse conto não há nem bom nem mau, muito legal. Giovani

Pelo depoimento dos alunos observamos que este trabalho gerou uma nova compreensão das possibilidades de entendimento deste conto e, conseqüentemente, dos demais contos conhecidos pelo grupo. Observamos na fala da Mariana a ruptura estabelecida com o estereótipo da princesa delicada, frágil e indefesa, em oposição à madrasta má. Este questionamento pode ser confirmado no depoimento do Giovani ao dizer que neste conto não há nem bom, nem mau.

Demos continuidade ao trabalho com os jogos teatrais para a experimentação do conto, estabelecendo relações entre o Onde, o Quem e o O Que. Destas experimentações, chegamos a algumas definições sobre a estrutura dramática desejada pelo grupo e sobre o que contaríamos através desta montagem.

Questionei o grupo sobre quais relações estabeleciam entre o conto e a atualidade. Foram apontados os seguintes aspectos:

- Dependência dos filhos para com os pais;

- Diferenças sociais;

- Amor;

- Pai mimar a filha;

- Ajuda da velha - solidariedade;

- Tolerância;

- Sofrimento para conquista e

- Vingança.

Sobre a vingança ser o que move a princesa houve um grande debate já que parte do grupo vê as ações dela como vingança e outra parte não. 
Foi decidido, pelo grupo, que contariam uma história de amor, explicando através da peça o processo para que o amor aconteça e de que forma o sofrimento foi necessário para que eles, príncipe e princesa, ficassem juntos.

Decidimos em que época gostaríamos que a peça se passasse, se na atualidade ou no tempo do conto de fadas e definimos que nos utilizaríamos dos dois tempos, misturando as possibilidades. Embora o tempo dos contos de fadas seja bastante indefinido, a referência do grupo é aquela apresentada pelos filmes da Walt Disney.

Ficou definido também que manteríamos a presença do narrador. Discutimos amplamente as possibilidades, estabelecendo relações e significados para o conto e para os jogos que havíamos feito a partir dele. O melhor exemplo encontrado entre um espaço do conto e da atualidade foi em relação ao nicho, entendendo-se que poderia ser representado como o casamento, no qual a mulher cuida da casa sem parar, estando presa a ela.

O passo seguinte a todas estas decisões foi jogar partindo de um roteiro de cenas levado por mim. ${ }^{16} \mathrm{O}$ roteiro foi definido principalmente pelas ações contidas na história, de forma bem detalhada e com cada cena contendo apenas uma ação da narrativa. A elaboração do roteiro ocorreu após a realização dos jogos com o texto narrativo.

Os personagens presentes no roteiro foram os que permaneceram na versão dramática, excetuando o mordomo, a rainha (mãe da princesa), os operários, o servo do príncipe e todos os empregados do castelo da princesa que estão implícitos na narrativa. Todas estas exclusões se devem ao fato de havermos considerado tais personagens desnecessários à estrutura dramática, sem nenhuma inserção significativa, podendo dessa forma ser excluídos, não ocasionando nenhuma perda.

\footnotetext{
${ }^{16}$ Ver apêndice 2.
} 
Levando em conta que o pressuposto fundamental dessa investigação é o de que o texto traz em seu bojo múltiplas possibilidades de significado, a serem exploradas pelo grupo que se dispuser a jogá-lo teatralmente (Pupo, 1997:7), o roteiro foi apresentado ao grupo e junto com ele sugeri um jogo para cada uma das cenas. Todos os jogos sugeridos já haviam sido experimentados anteriormente com o grupo.

Partindo da idéia apresentada por Pupo, exploramos o roteiro com os jogos de tal forma que a história narrada e o texto com o qual havíamos trabalhado pudessem, através do jogo, elucidar quais as possíveis relações com o cotidiano dos alunos e com o que gostaríamos de contar nesta apresentação.

Relato, a seguir, todas as cenas exploradas, que pelo jogo tiveram a estrutura do texto dramático definida.

CENA 1: os narradores apresentam os personagens explicando que a princesa está fazendo 15 anos. Foi proposto inicialmente que fossem dois narradores contando o fato um para o outro. As soluções encontradas foram:

- Dois "amigos" da princesa comentando o seu aniversário, tempo atual e linguagem coloquial.

- Um pai contando a história para o filho na hora de dormir.

- Duas pessoas lendo o jornal, falando da princesa e de seu aniversário como se fosse uma notícia do dia, discutem religião e falam sobre o reino.

- Dois narradores indistintos, contando a história como de um reino distante.

- Duas Bêbadas, tempo atual, comentando o aniversário.

- Um jornaleiro gritando na rua, vendendo jornal para um comprador. 3 Jogadores ao mesmo tempo:

- Vendo televisão e repetindo alto o que assistiam (referência evidente aos jogos: O que estou vendo? e Envolvimento com o ambiente imediato. ${ }^{17}$ ) 4 Jogadores ao mesmo tempo:

${ }^{17} \mathrm{O}$ jogo $\mathrm{O}$ que estou vendo? Propões aos jogadores assistirem a um esporte imaginário, deixando presente o movimento e ações dos esportistas. O jogo Envolvimento com o ambiente imediato propõe o contato com o espaço mais próximo ao jogador. 
- Amigos papeando e comentando o aniversário e a festa da princesa.

Todos os jogadores:

- Um musical, todos cantando.

- Em uma sala de aula todos comentando, disfarçam para a professora não ouvir.

- Telefone sem fio.

Embora as propostas tenham sido feitas para a cena 1, algumas delas foram retomadas em outras cenas. O "telefone sem fio" foi escolhido como solução para a última fala do texto, "casaram e viveram felizes para sempre" e foi dito por todo o grupo.

Cena 6: o pássaro rouba o pente da princesa. Foi proposto que todos os movimentos fossem feitos em câmera lenta. Nas quatro vezes que foram feitas essa cena com duplas diferentes, o ator que fazia a princesa usou uma peruca de cabelos cacheados e embaraçados, levada por uma das alunas, o que fez com que as cenas tivessem uma qualidade cômica muito interessante, ainda mais por estarem ressaltadas pela lentidão dos movimentos.

- A cena foi feita pela Solange (pássaro) e pelo Giovani (princesa) e com a tentativa da princesa se pentear em câmera lenta, deixando os fatos muito exagerados. A princesa optou por poucas palavras, falando: Por que?, Volta aqui!, Meu pente!, Voltaaa!, Paaaai!

- A cena foi feita pela Sidnéia (princesa) e pela Priscila (pássaro). No momento que o pássaro rouba o pente a princesa cai no chão e vai se arrastando em direção à janela, ameaçando-o de morte.

- A cena foi feita pelo Daniel (princesa) e pelo Edmilson (pássaro) que só falou "arara".

- A cena foi feita pela Priscila (princesa) e pela Mariana (pássaro) e ela comenta que seu cabelo nunca foi penteado. 
As soluções encontradas pelos alunos nesta cena definiram a escolha por não incluir quase nenhuma fala neste momento e deixar que a relação entre a princesa e o pássaro ficasse marcada, fundamentalmente, através da movimentação, como pode ser observado na figura 9.

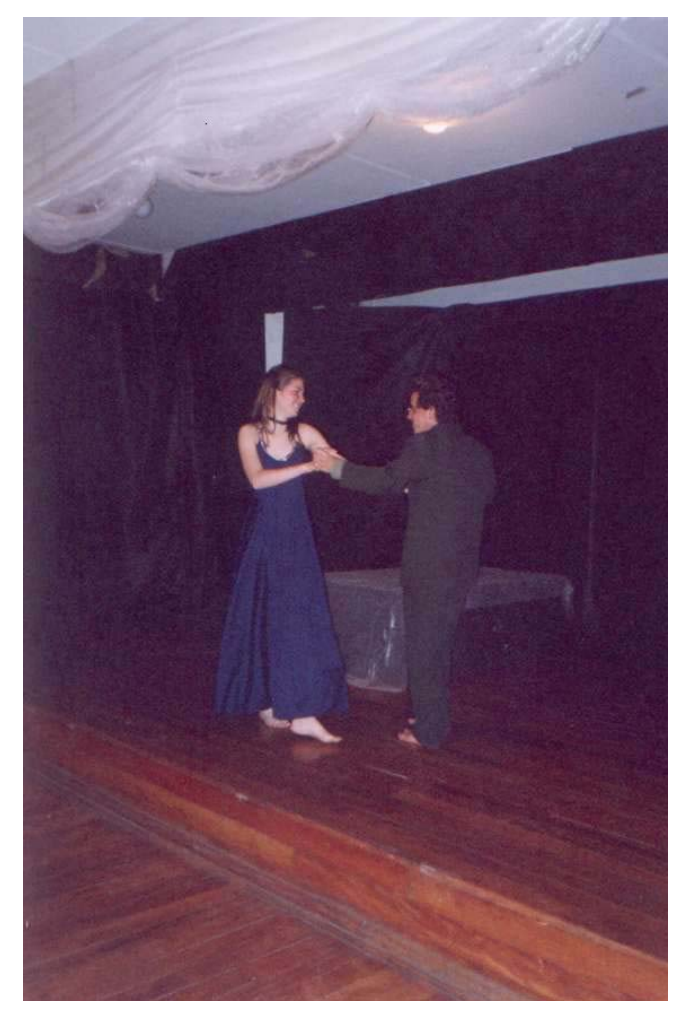

Figura 9:Improvisações da cena do roubo com os personagens do pássaro e da princesa.

Cena 9: o narrador explica que a princesa está muito doente e no meio da cena entra o arauto conclamando o povo para divertí-la, dizendo que quem conseguisse poderia se casar com ela. Foi proposto que toda a cena fosse feita com o corpo sustentando o movimento, utilizando apenas a voz, o que resultou em:

- O tempo usado foi o atual, o arauto entrou como um guarda e o narrador falava como uma pessoa da cidade, ao comentarem a decisão do rei falaram muito mal da princesa, variando o tom de voz.

- Arauto caipira e meio gago. Discutiram para saber qual dos dois conseguiria a mão da princesa.

- Narrador em tom de telejornal, arauto "dando bronca". Os dois disputaram por conseguir distrair a princesa. 
Ao optarmos pela manutenção da história mesclando o tempo indefinido dos contos de fadas misturado com o atual, alguns personagens se aproximaram mais de um ou de outro, conforme as características do mesmo. $O$ arauto, por ser um personagem muito distante da realidade atual, manteve-se com as características do "tempo do conto de fadas" e a linguagem utilizada por ele foi muito pouco coloquial, tentando manter o tom de representante do rei.

Cena 12: o menino explica para a princesa o que havia visto na floresta e no palácio. Foi proposto o Exercício para as costas $n^{\circ} 1^{18}$ para a princesa e para 0 menino o jogo Verbalizando o Onde - parte $1^{19}$. As costas da princesa foram muito expressivas, mostravam toda a ansiedade em saber a história, expressando cada alteração de humor conforme a narrativa. O menino foi muito detalhista, comentando todo o espaço presente na sua fala.

O fato deles terem uma preocupação além do que o ocorrido na cena fez com que o texto dito fosse muito mais fluente e elaborado. Essa fluência possibilitou a criação de muitas falas que foram posteriormente incorporadas ao texto dramático.

Cena 13: a princesa está debaixo da cama, o pássaro entra, transforma-se em príncipe e ela se revela, dizendo que ficará no nicho todo o tempo necessário para que ele perca a maldição. Foi proposto o jogo Dificuldade com pequenos objetos para o príncipe e para a princesa o jogo Sussurro no palco ${ }^{20}$, até o momento que ela sai de debaixo da cama. Então o jogo comum passaria a ser Contato $^{21}$. Na primeira vez que foi realizada a proposta, o príncipe foi feito por uma aluna (Priscila) e o fato dela tentar masculinizar os próprios gestos deu uma comicidade à cena que fez com que os demais elementos se perdessem.

\footnotetext{
${ }^{18}$ Este jogo deve ser feito com o jogador todo o tempo de costas para a platéia, expressando-se com as costas.

${ }^{19}$ Neste jogo deve ser verbalizada toda a ação realizada.

${ }_{21}^{20}$ Neste jogo deve ser definido um Onde que solicite uma fala sussurrada.

${ }^{21}$ Neste jogo, toda a fala deve ser acompanhada por algum contato físico entre os personagens.
} 
Na segunda vez foi mantida a seriedade, não houve nenhuma intenção de tornar a cena cômica e cada um dos jogos pode ser realizado. A cena ganhou em qualidade, a princesa comentava cada uma de suas emoções ao ver o pássaro se transformar em príncipe, o que fez com que o príncipe ficasse quase todo o tempo em silêncio. $O$ contato entre os dois jogadores ocorreu no final da cena. As falas improvisadas neste jogo também foram incluídas no texto dramático.

Cena 14: a princesa está presa no nicho e, como já havíamos comentado com o grupo a relação entre a situação da princesa e mulheres donas de casa, a cena estava composta pela princesa no nicho e por mulheres fazendo serviços de casa. Foi proposto o Jogo do Espelho ${ }^{22}$ para as mulheres donas de casa, o que funcionou muito bem, criando relação entre os jogadores e fazendo com que muitas ações aparecessem. A princesa, por estar no nicho, foi ficando cada vez mais entediada e conforme o jogo se realizou ela ficou mais e mais caída, como pode-se observar na figura 10.

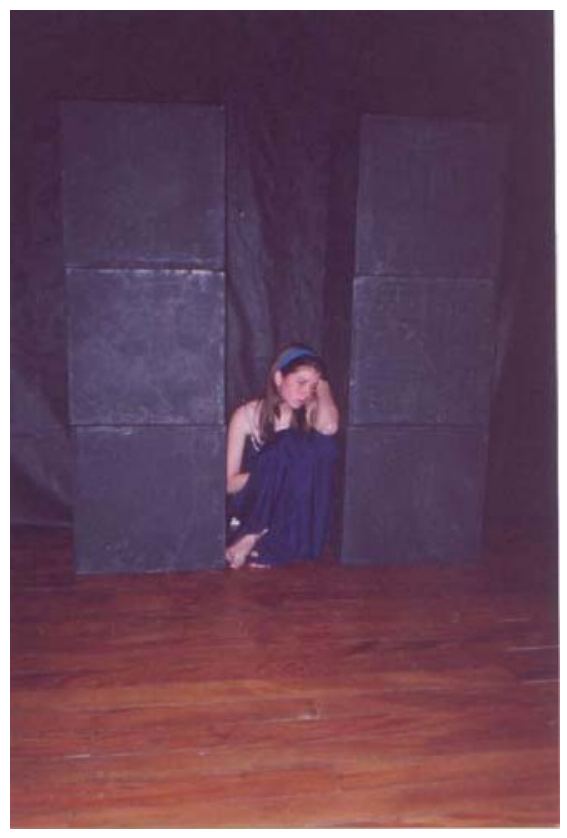

Figura 10: Princesa no nicho

\footnotetext{
${ }^{22}$ Neste jogo os jogadores deverão espelhar a ação um do outro.
} 
A realização deste jogo fez com que este momento da história ficasse sem nenhuma fala dos personagens, já que, ao incluirmos os personagens das donas de casa, estabelecemos um diálogo entre o momento vivido pela princesa e o cotidiano atual de muitas mulheres. A gestualidade dos personagens foi trabalhada pelo ato de jogar. Segundo Koudela:

Identificamos no sistema de jogos teatrais a possibilidade de trabalhar com o significado do gesto. O processo se fundamenta no jogo e na ação improvisada. O que diferencia o método é a seqüência gradual de problemas solucionados, que levam não apenas à liberação da ação lúdica, mas também à decodificação da estrutura da linguagem. (Koudela,1990:43)

Os gestos criados para esta cena já continham em si as informações necessárias para a compreensão da narrativa e ampliaram a visão apresentada pelo conto com a relação estabelecida pelo grupo.

Cena 15: o príncipe abre a porta do nicho e diz para a princesa que não a quer mais. Foi proposto o jogo Contato através dos Olhos $^{23}$. A fala do príncipe estava proposta no texto/roteiro e não havia nenhuma fala proposta para a princesa, o que fez com que ela ficasse muito quieta. Na segunda vez que jogamos, a Sidnéia fez o príncipe e o fez como um homem atual, falando gírias, "malaco", que usava expressões como - "Mó fubanga". ${ }^{24}$

Cena 17: o narrador explica que a princesa construiu um palácio na frente do palácio do príncipe e este se apaixonou por ela sem reconhece-la. Foi proposto o jogo Contato através dos olhos ${ }^{25}$ com a platéia. Fizemos a cena com todos os participantes presentes e cada um deu uma solução muito diferente da do outro. A Priscila conversou com a platéia, com uma linguagem atual e cheia de gírias; entrou falando da vingança, com frases do tipo: - "Vocês sabem, né? A vingança tá chegando." A

\footnotetext{
${ }^{23}$ Neste jogo qualquer fala deve ser acompanhada de um contato visual entre os jogadores.

${ }^{24}$ Esta linguagem foi utilizada na montagem pelo personagem do menino tonto, feito pela Sidnéia. A Sidnéia foi a aluna que mais se identificou com o personagem do menino tonto - menino de rua e conforme realizamos os jogos, as características deste menino de rua apareciam com maior intensidade, mesmo quando os personagens propostos eram outros.

${ }_{25}$ Já explicado neste capítulo, porém neste caso deveria ocorrer a relação com a platéia.
} 
Sidnéia fez uma fofoqueira esquecida e com raiva dos homens e a Michelle falou como se todos pudessem ver o palácio. A solução que deixou o palácio presente foi a utilizada para o texto dramático.

Cena 18: o príncipe está olhando para o castelo da princesa, entra o rei e o príncipe o convence a pedí-la em casamento. Foi proposto o jogo Que horas são ${ }^{26}$. 0 olhar para o palácio ficou presente nas duas vezes que realizamos o jogo, porém em uma delas não foi possível identificar a hora do dia. Na segunda vez que foi escolhida a madrugada como hora, ficou muito claro e a conversa entre os personagens fluiu com tranqüilidade.

Ao escrevermos esta cena, retomamos a madrugada como o horário no qual ela acontece e o diálogo entre o rei e o príncipe ficou definido tendo como base este momento. Esta caracterização, além de definir as frases utilizadas, também elucida com muito mais clareza a intensidade da paixão vivida pelo príncipe, já que fica implícito que o mesmo perde o sono na tentativa de olhar para a princesa. Esta definição possibilitou a ausência de outros momentos que explicassem, com maior detalhamento, o sofrimento do príncipe pelo amor da princesa. Como enfatiza Hirsch:

O espetáculo teatral dispõe de um apelo sensorial (visual e sonoro) que o livro não tem. Logo, as descrições, via de regra, são o testemunho daquilo que "viu" e "ouviu" o narrador da fábula. Estas descrições, em sua maioria, são o suporte do figurino, da cenografia, da iluminação, da sonoplastia e da composição das personagens. (Hirsch, 1988: 36)

Neste momento da história, pudemos contar não apenas com os elementos que o espetáculo teatral dispõe, tais como iluminação e figurino, mas também, com a escolha de um horário para a realização da cena que traduziu aspectos da narrativa. ${ }^{27}$

\footnotetext{
${ }^{26}$ Neste jogo a hora do dia deve ficar evidenciada pelas ações dos personagens.

${ }^{27}$ A frase escolhida pelo rei para iniciar esta cena foi: Mas o que você ta fazendo aqui a estas horas?
} 
Cena 23: casamento na ponte de cristal. Foi proposto o jogo Quadro de cena ${ }^{28}$. Ficou evidente a noção de grupo no decorrer da cena, em todos os momentos os participantes tinham a percepção dos demais jogadores e da composição da cena no espaço. O diálogo ocorreu no tempo atual, no momento que a princesa desiste de casar, o príncipe se jogou no chão, se arrastou atrás dela implorando por seu amor e o rei ficou comentando sobre a postura tomada por seu filho, que não fora criado para se arrastar por ninguém.

As falas escolhidas para esta cena ficaram muito próximas ao jogo realizado. As características do rei, pai do príncipe, presentes no conto, evidenciaram-se ainda mais nesta cena, assim como o estado de desespero do príncipe. A diversidade de soluções para os personagens trabalhados pode ser vivenciada no jogo teatral. Esta possibilidade está presente na estrutura do jogo, conforme explica Pupo:

As proposições de jogo que pretendiam examinar essa relação [entre personagem e jogador] tinham como pressuposto a não identificação entre quem representa (jogador) e o que ele representa (personagem). Esse pressuposto recobre os próprios princípios do jogo teatral: uma abordagem mais lúdica do que mimética do enredo, a ênfase no aspecto grupal da experiência em oposição ao culto do estrelato, e como decorrência, o trânsito possível de todos os jogadores através de todos os personagens." (Pupo, 1997:92)

A exploração do roteiro, mantendo-se a liberdade de escolha dos jogadores em se colocarem no papel de qualquer personagem deu, não apenas a possibilidade de ruptura da idéia de atores principais, melhores e mais capacitados, como também de um entendimento diferenciado de cada um dos personagens e da história contada.

Embora tenha sido feita a opção, por cada um dos participantes, de assumir um dos personagens para a construção e apresentação da peça, essa exploração com a

\footnotetext{
${ }^{28}$ Neste jogo todos os jogadores devem ter a percepção do grupo e quando o coordenador disser a expressão "quadro de cena" todos devem sustentar o movimento, observando se todos os participantes estão visíveis para a platéia. Caso não estejam, devem se reorganizar no espaço para que passem a ficar.
} 
troca dos personagens deu a todos a noção da flexibilidade possível em uma encenação.

A seqüência de jogos partindo do roteiro de cenas, somada às diversas experimentações com o conto foi a base para a transcriação do conto para o teatro. Da narrativa oral, passamos para o trabalho com o texto transcrito para o papel que, por intermédio do jogo teatral, se transformou em texto dramático. ${ }^{29}$

A compreensão do conto O Pássaro Verde foi se transformando no decorrer do processo, o que pode ser evidenciado pelas resposta à pergunta realizada no final do projeto: Sua compreensão sobre o conto $O$ Pássaro Verde foi transformada no decorrer do nosso trabalho?

Sim, eu entendi melhor a reação da princesa em relação ao príncipe. Mariana

Sim pois eu sinceramente não botava fé nesse conto mas aos poucos fui percebendo o quanto eu estava errado a respeito do conto e como ele foi bom para todos. Edmilson

Foi! Cada dia que eu lia mais uma vez, eu entendia mais uma coisa, mais um mistério da história, mais uma conclusão. Priscila

Sim pois eu achava um pouco infantil a história, mas depois compreendi a sua mensagem (o que deixou de ser tão infantil). Daniel

Sim, com o decorrer do trabalho e como foram colocados os jogos a minha visão sobre o conto foi totalmente transformada. Solange

No começo, achava que a princesa não precisava perdoar o príncipe, na verdade ainda acho, mas ia perder o sentido se não fosse assim. Giovani

Pelos relatos dos alunos, observamos a transformação ocorrida em cada um sobre o significado do conto e dos conceitos que ele apresenta. O entendimento das relações amorosas, o conceito de perdão e vingança, foram diversas vezes discutidos e novos significados foram atribuídos.

\footnotetext{
${ }^{29}$ Ver Apêndice 3.
} 
Pupo nos mostra a amplitude que o texto literário abre para o questionamento da visão de mundo e a importância do jogo nessa busca de novas compreensões da realidade.

O texto literário descortina um universo ficcional que nos permite ampliar nossa apreensão do mundo. Mediante a ficção vive-se "outras vidas" que podem conduzir o fruidor a desvendar perspectivas até então não reveladas sobre o ser humano. (...) Diante do texto, o jogador é convidado a selecionar significados, a deslocar ou a re-significar dimensões por ele sugeridas. A partir dessas escolhas, formula-se um discurso teatral que emerge de regras de jogo. (Pupo, 1997:149/150)

Explorar os diversos significados que este conto teve para o grupo, as relações que suscitou com o momento vivido por cada um dos participantes foi uma possibilidade de dar um novo olhar ao conto, tanto a esse como aos demais com que cada um possa ter tido contato. Essa percepção pode ser evidenciada nas respostas dadas por eles à pergunta: Como foi trabalhar com um conto?

Foi legal... embora não envolva um tema polêmico, que geralmente se torna mais interessante trabalhar, eu gostei muito. Mariana

Foi legal pois geralmente esses contos tem uma certa magia, uma inocência e isso é legal. Edmilson

No início achei meio bobo e sem graça, queria fazer uma coisa mais moderna, interpretar uns papéis engraçados ou dramáticos. Mas depois, eu adorei, e achei bem divertido, só por ser um conto. Priscila

Trabalhar com um conto da maneira como nós trabalhamos foi muito gratificante e não foi tão boba como eu achava que todas as peças de contos são. Solange

Foi ótimo, pois num "conto de fadas" tudo pode acontecer, foi aí então que tivemos que trabalhar com as nossas imaginações. Daniel 
Nesta fala do Daniel percebemos o quanto esse trabalho gerou a exploração do imaginário de cada um, o quanto a imaginação fez parte de todo o processo de construção de um fazer teatral gerado da narrativa do conto O Pássaro Verde.

O entendimento dessa história foi construído com a realização dos jogos e a reflexão sobre cada momento deste processo, vivido por todo o grupo.

Chegamos então ao último momento de transformação da história. O passo seguinte à exploração do roteiro através dos jogos foi a definição do texto dramático, com uma formalização que se aproximaria do texto a ser dito no momento da apresentação da peça.

O texto dramático foi feito por mim e apresentado para o grupo. A opção da escrita do texto não ser coletiva deveu-se, fundamentalmente, a dois fatores: o tempo necessário para a realização de uma escrita coletiva era incompatível com o tempo de que dispúnhamos; e a dificuldade com a linguagem solicitaria um trabalho amplo junto ao grupo para que todos pudessem de fato participar da elaboração, o que não era foco desta pesquisa. Como a proposta era de continuarmos com a montagem da peça com os jogos teatrais, a possibilidade de transformação de parte das frases definidas no texto era bastante alta.

A construção do texto dramático e o entendimento de sua estrutura também podem ser avaliados através das respostas à pergunta: Sua visão sobre um texto teatral mudou com esse trabalho?

Pra falar a verdade eu nunca tinha pensado em como era um texto teatral... mas eu o vejo como um diálogo que se for só decorado fica frio, preciso entender o sentido da frase de cada palavra... Mariana

De certa maneira sim pois tive uma visão mais ampla do que é teatro. Edmilson

Mudou, achava que era bem mais difícil. Mas com o tempo você pega o jeito, adora e não quer mais parar. Priscila 
Minha visão mudou pouco, pois eu achava que o que estávamos fazendo, já era por mim esperado. Daniel

Sim, mudou completamente hoje eu tenho outra visão sobre um texto teatral! Solange

Sim, pois o texto teatral tem aquele negócio de :

Fulano:

Cicrano: ---------, é muito diferente. Giovani

Nos depoimentos fica clara a pouca noção da forma do texto dramático. A visão da estrutura do texto através dos diálogos era escassa para cada um dos integrantes, o que denota o pouco contato com a literatura teatral.

Entendo que, através da exploração do conto com o jogo teatral, foi possível redimensionar seu significado. Desde a forma encontrada para narrá-lo, passando pela transcrição do oral para o escrito, o roteiro das cenas, até o texto dramático, este conto foi recontextualizado, refletindo as opiniões, dúvidas, questionamentos, posições e o momento histórico do grupo que participou deste projeto.

Kátia Canton nos fala da descontextualização sofrida pelo conto de fadas:

Com a apropriação pelas editoras, pela indústria publicitária e de entretenimento, o conto de fadas se tornou mitificado. Foi desistoricizado e esvaziado de autoria, contexto e ideologia. O conto de fadas se tornou um mito e foi preservado coletiva e anonimamente, e seus traços históricos, culturais e ideológicos foram transformados no "natural", ou seja, foram neutralizados. O conto de fadas foi expropriado e corrompido pela indústria cultural para se tornar atemporal, universal, o bom senso, a norma" (Canton, 1994:59)

O trabalho com o jogo teatral possibilitou ao grupo um novo entendimento do Conto de Fadas, deixando que $O$ pássaro verde dialogasse com o cotidiano de cada um. Nos envolvemos nesta história de forma que fosse possível recriála, transformando-a em uma história nossa, de todo o grupo. 
Nos dias frios de inverno, com vento e neblina, fui cada vez mais me enrolando e aquecendo no tecido daqueles textos. (Machado, 2001:20)

Os nossos dias não foram apenas de inverno, passamos por todas as estações do ano e, se considerar o primeiro momento de narrativa deste conto, diria dos muitos anos, mas me sinto igualmente enrolada e aquecida por estas histórias: a que foi ponto de partida, o texto dramático e a montagem teatral resultante de todo este processo. 


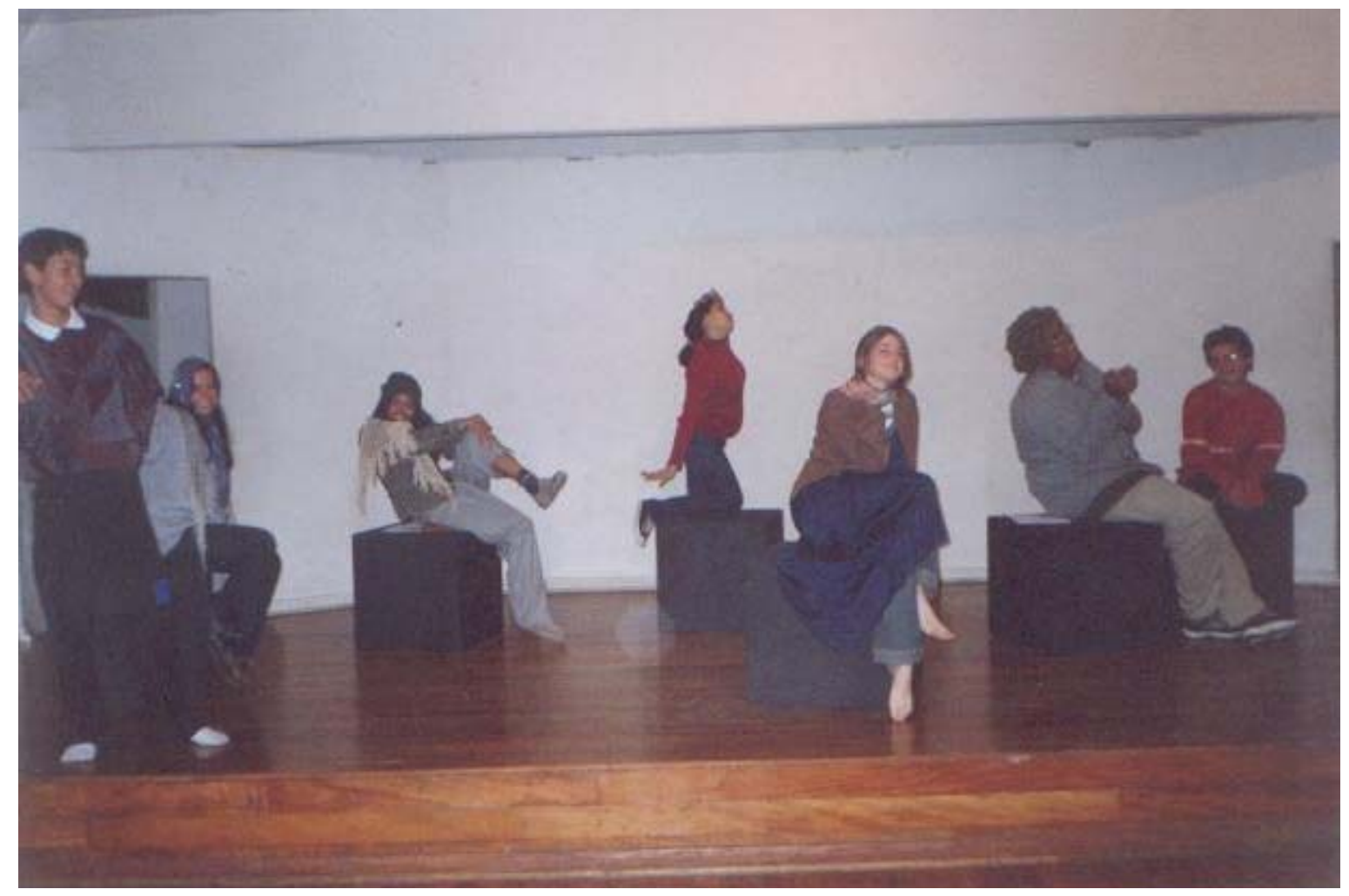

Como se houvesse alguma realidade verdadeira que não incluísse a magia e a fantasia, não incorporasse o delírio e a imaginação. 


\section{CAPÍTULO 2: Estudo sobre "O Jogo Teatral no Livro do Diretor"}

Este capítulo pretende discutir o papel ocupado pelo sistema de jogos teatrais proposto por Viola Spolin, analisando de maneira detalhada o livro O Jogo Teatral no livro do diretor (Spolin, 1999), com a intenção de observar como esta publicação pode contribuir para o professor que trabalha com grupos de alunos da escola formal.

Viola Spolin inicia suas publicações sobre o trabalho teatral com Improvisação para o teatro (Spolin, 1963) que, assim como toda sua proposta de jogos teatrais, está baseado na prática, no fazer teatral e no aprendizado que se pode obter com esta vivência.

Dividido em quatro sessões, o livro apresenta uma enorme variedade de jogos teatrais, além de fundamentar sua proposta e apontar especificidades do trabalho com crianças. Expõe os princípios básicos do sistema de jogos teatrais, propondo através dos jogos uma forma pela qual podemos ensinar teatro.

A publicação de Improvisação para o Teatro, no Brasil (Perspectiva:1987), possibilitou a divulgação deste sistema, assim como uma ampla discussão sobre o ensino de teatro. Spolin apresenta um sistema de jogos teatrais no qual, por meio de jogos de regras que dão uma estrutura para a improvisação, o ator/jogador passa a ser o sujeito de sua educação.

A apropriação deste sistema pode ser evidenciada na prática de diversos pesquisadores que descrevem a riqueza que esta proposta apresentou para o ensino de teatro.

Ingrid D. Koudela, nos vários estudos feitos sobre jogos teatrais, apresenta diferentes possibilidades de utilização do jogo, discutindo o papel do mesmo como elemento fundamental para o entendimento do ensino de teatro. Koudela também traz uma importante contribuição para esta pesquisa em seu trabalho Texto e Jogo 
(Koudela, 1996), em que, por meio da peça didática de Bertolt Brecht, podem ser observadas possibilidades de inserção do jogo teatral. De acordo com a autora:

Spolin sugere que o processo de atuação no teatro deve ser baseado na participação em jogos. Por meio do envolvimento criado pela relação de jogo, o participante desenvolve liberdade pessoal dentro do limite de regras estabelecidas e cria técnicas e habilidades pessoais necessárias para o jogo. À medida que interioriza essas habilidades e essa liberdade ou espontaneidade, ele se transforma em um jogador criativo. Os jogos são sociais, baseados em problemas a serem solucionados. O problema a ser solucionado é o objeto do jogo. As regras do jogo incluem a estrutura (Onde, Quem, O Que) e o objeto (Foco) mais o acordo de grupo (Koudela: 1990:43).

Ao nos determos na formação do aluno entendemos o significado que as regras podem assumir no desenvolvimento infantil e a sua importância na estrutura, presente no sistema de jogos teatrais apresentado por Spolin.

A publicação de O Jogo teatral no livro do diretor (Spolin,1999), por sua vez, possibilitou uma abertura para a discussão da utilização do sistema de jogos teatrais para ensaios.

Ao pensarmos na enorme defasagem de formação dos professores quanto à possibilidade de trabalhar a linguagem teatral dentro das escolas, é fundamental a existência de bibliografias que possam suprir esta lacuna. Evidentemente, a consulta ou estudo teórico de uma proposta de ensino de teatro não suprirá as dificuldades apresentadas, já que para um bom entendimento do jogo, é necessário jogar. Entretanto, dadas as circunstâncias de boa parte das escolas e de seus professores, nem sempre será possível participar de um curso que dê continuidade à formação dos professores. Neste caso, é muito importante contar com um texto que apresente de forma clara suas propostas. ${ }^{30}$

\footnotetext{
${ }^{30}$ Ressalto a importância de que o professor tenha contato não apenas com os livros que orientam a prática do jogo teatral, mas também que fundamentem sua proposição. Para tal, além dos demais livros de Spolin, podem ser consultados outros autores também citados nesta pesquisa.
} 
O livro de Spolin apresenta uma seqüência de passos a serem tomados no decorrer do processo de montagem de uma peça teatral, estabelecendo possibilidades de jogos teatrais para cada um dos momentos de uma montagem, dividindo este processo em etapas com determinadas características e dificuldades que poderão ser trabalhadas com o uso de jogos teatrais.

Em cada jogo temos, além da descrição do mesmo, o objetivo, o foco, as instruções a serem dadas, a avaliação e as notas.

A descrição diz ao diretor como organizar o jogo, onde posicionar os jogadores, quando começar a fornecer instruções técnicas, quando deter o jogo etc. Esta forma de apresentar os jogos dá ao leitor um bom entendimento de como o jogo poderá ser apresentado e conduzido pelo coordenador ${ }^{31}$.

O objetivo define o principal resultado que um diretor espera obter de cada jogo. Será com a consulta dos objetivos dos jogos que os diretores poderão resolver problemas específicos que possam surgir.

Freqüentemente, no desenrolar do trabalho teatral, aparecem dificuldades que não puderam ser previstas pelo coordenador. Poder consultar os jogos, sabendo qual o objetivo de cada um, é uma forma facilitadora de encontrar soluções que dêem andamento ao trabalho.

O foco é entendido como a direção que a atenção do ator/jogador deve tomar. O Foco garante o envolvimento de todos os participantes em cada momento durante $o$ processo do jogo.

A existência de um foco com o qual os jogadores e o coordenador trabalharão no decorrer do jogo, cria para os participantes um ponto de vista e uma objetivação do

\footnotetext{
${ }^{31}$ O papel do diretor e do coordenador dos jogos é assumido pela mesma pessoa, já que a proposta de Spolin é de que o processo de ensaios seja realizado com a utilização dos jogos.
} 
que devem fazer em cena. Este direcionamento que o foco estabelece dá a liberdade de criação necessária ao jogador, já que ele voltará sua atenção para um aspecto previamente definido.

A objetivação do problema a ser solucionado, através do foco, abre um espaço de relação com o outro que possibilita a quebra de respostas estereotipadas, de comportamentos na relação de grupo baseados no costume, na convenção estabelecida pelo próprio grupo; já que o jogo apresenta desafios nos quais o jogador necessita estabelecer contato com o ambiente para que encontre as diferentes formas de solucioná-lo.

O foco aponta para o jogador qual aspecto ele terá de estar atento, priorizando o problema estabelecido pelo coordenador na proposição do jogo. Esse direcionamento possibilita a improvisação, sem que o jogador perca seu referencial no processo.

As instruções são as informações que serão dadas pelo diretor aos atores/jogadores enquanto o jogo está sendo jogado. É o elo entre diretor/instrutor e os atores/jogadores.

Durante o desenrolar dos jogos, o coordenador deverá, através das instruções, manter os jogadores dentro das proposições apresentadas inicialmente. Esta orientação possibilita o melhor entendimento e realização da proposta. Koudela salienta:

As instruções são enunciados diretos, propostos pelo coordenador, enquanto o jogo está acontecendo. A função da instrução é promover as ações improvisadas, auxiliando o jogador a manter o foco no problema de atuação que está sendo trabalhado. Através da instrução, o coordenador estabelece uma relação de parceria com os jogadores que estão em cena. (Koudela: 1996: 24) 
A avaliação consiste em questões seja para os atores/jogadores seja para os observadores. A avaliação revela o que foi percebido, aprendido e/ou realizado no curso do jogo. A avaliação é feita por todos os participantes, porém, com a orientação do coordenador.

Ao avaliar o jogo realizado é necessário que o coordenador tenha muita clareza dos objetivos. A avaliação deve ser entendida como um momento de questionamento sobre o jogo que foi realizado, observando-se se o grupo manteve o foco presente.

As notas, presentes na apresentação de cada jogo proposto por Spolin, são observações que levam à uma melhor compreensão, apontando quais dificuldades podem surgir no jogo e como resolve-las, que oportunidades devem ser procuradas, que outros jogos se relacionam a este etc. (Spolin: 1999)

Embora exista uma breve definição de cada um destes itens na apresentação inicial da estrutura do jogo, alguns serão retomados no primeiro capítulo de $O$ jogo teatral no livro do diretor (Spolin, 1999), quando a autora expõe vários conceitos que norteiam o trabalho. ${ }^{32}$

A apresentação visual do jogo presente no livro possibilita que cada um dos itens mencionados seja imediatamente identificado, agilizando a utilização dos mesmos.

$\mathrm{Na}$ apresentação do livro, feita por Koudela, o sistema de jogos teatrais foi contextualizado no espaço educacional.

No contexto da educação, vários autores contribuíram para uma fundamentação teórica do método de Jogos Teatrais e demonstraram a importância de sua aplicação com crianças e adolescentes. Significativa

\footnotetext{
32 Uma definição mais detalhada de conceitos também pode ser encontrada em Improvisação para o Teatro (Spolin, 1987).
} 
neste debate é a importância atribuída ao teatro no processo educacional, como um meio para a educação estética. Os Jogos Teatrais são muitas vezes relacionados com uma forma de aprendizagem cognitiva, afetiva e psicomotora embasada no modelo piagetiano para o desenvolvimento intelectual.(In: Spolin: 1999)

Spolin apresenta também as regras como um processo de interação do grupo que, através do envolvimento estabelecido, irá possibilitar a liberdade pessoal para os jogadores e expõe a visão do teatro como realidade cênica apresentado no sistema de jogos teatrais.

O livro está organizado em sete capítulos, sendo que do segundo ao sexto capítulos a autora apresenta os diferentes momentos para a montagem de uma peça de teatro, tendo como base os jogos teatrais. Organizei este capítulo de minha pesquisa, seguindo a ordem proposta por Spolin, já que as atividades realizadas com o grupo de teatro Pé Sujo foram estruturadas mantendo esta mesma seqüência. Entendi que a melhor maneira de observar a pertinência deste livro como um material enriquecedor para a prática pedagógica do professor de teatro, seria mantendo a proposição apresentada por Spolin.

Sendo assim, o livro será analisado, estabelecendo um paralelo com as situações vivenciadas pelo grupo de teatro no experimento proposto por mim nesta pesquisa.

\section{PREPARAC̄̃̃O}

No primeiro capítulo intitulado Preparação, Viola Spolin apresenta diversos aspectos do fazer teatral e do sistema de jogos teatrais, definindo papéis e funções dentro do processo de montagem. Os conceitos são apresentados sob forma de tópicos. O primeiro conceito explorado será o de presença.

Atuar requer presença. Aqui e agora. Jogar produz esse estado. Da mesma forma que os esportistas estão presentes no jogo, assim também devem estar todos os membros do teatro no momento de atuar. (...) A presença 
chega através do intuitivo. Não podemos aproximar a intuição até que estejamos livres de opiniões, atitudes, preconceitos e julgamentos. O próprio ato de procurar o momento, de estar aberto aos parceiros de jogo, produz uma força de vida, um fluxo, uma regeneração para todos os participantes.(Spolin, 1999:17)

A presença é fundamental à atuação e poderá ser atingida através do jogo, desde que o jogador consiga distanciar-se da expectativa mental sobre o que está fazendo e se coloque no jogo. Ela indica que este caminho será alcançado através do físico, possibilitando que o jogador se coloque no momento presente, deixando de estar na memória. Estar no presente é o que possibilitará o acontecimento do novo, do inesperado.

Os jogadores que se perdem no personagem, nas emoções e nas atitudes e ficam preocupados com "como estou me saindo?" estão confinados em suas próprias cabeças: fragmentados, isolados, solitários e perdidos. Eles vivem na memória (não no presente). (Spolin, 1999:18)

O diretor é alguém que participa do grupo, que deverá ter a sensibilidade para compreender as necessidades apresentadas por ele e propor a partir daí. Existe uma postura clara de parceria, seja do diretor para com os atores, seja dos atores para com a platéia, o que se dará através do reconhecimento do compartilhar, outro conceito presente no decorrer do trabalho. O uso de terminologias que exploram o conceito de compartilhar ao invés de terminologias convencionais de palco, evidencia esta postura de parceria.

Ao pensarmos no papel do professor de teatro dentro da perspectiva proposta por Spolin para o diretor, observamos a necessidade de que o mesmo se coloque dentro desta possibilidade de relação e percepção do grupo com o qual trabalha. Esta possibilidade se abrirá desde que o professor se predisponha para tanto e crie condições para isso. Se não quisermos estabelecer uma relação autoritária para com o trabalho, será necessário que o professor busque formas de manter esta qualidade de observador e propositor, em uma relação de diálogo com o grupo. 
Koudela esclarece o papel do coordenador na relação com os participantes:

É tarefa do coordenador desvendar crises e desmascarar soluções esquemáticas, costumeiras, convencionais.

A confiança que os participantes depositam no coordenador advém da sua capacidade de decifrar aquilo que não é solução, contribuindo com perguntas, dúvidas, multiplicidade de pontos de vista, comparações, lembranças, experiências. (Koudela, 1996: 115)

Quanto aos objetivos do diretor, Spolin aborda a importância de que este tenha familiaridade com os jogos que irá propor para que a peça emerja do próprio jogo. Enfoca também a necessidade do diretor não utilizar o trabalho como um espaço de realização de sonhos pessoais.

Entendo ser esta uma das principais dificuldades encontradas pelos professores ao trabalhar uma montagem. A situação escolar mantém uma hierarquia que propõe o professor como detentor do saber e pessoa que fará as escolhas pelo grupo de alunos com o qual trabalha. Esta característica dificulta muito a alteração do professor desta posição de "planejador", para a de organizador do trabalho coletivo. A dificuldade que os alunos encontram para entrar no jogo, permitindo-se estar no tempo presente, na relação com o outro, entendo que é ainda maior para o professor que define um objetivo para o trabalho e, junto com ele, uma imagem do que será a peça quando montada. Depois desta imagem estabelecida, é difícil que o professor se desprenda dela.

Para a escolha do elenco a autora levanta aspectos a serem observados, ressaltando a importância de que os atores selecionados sejam pessoas com condições para realizar o trabalho dentro do tempo previsto. Ela aponta a utilização da improvisação associada ao teste como uma forma de trabalho bem sucedido. Nas diferentes maneiras que o diretor poderá optar, ele deverá sempre ocultar as próprias ansiedades e evitar caracterizações muito detalhadas que levem à imitação das mesmas. 
Uma das qualidades exigidas do diretor, neste momento, é o insight para que ele possa perceber as características indefiníveis porém sensíveis.

No trabalho realizado junto ao grupo de teatro Pé Sujo, o elenco foi definido pelo interesse dos alunos em participar do curso. A única exigência feita para a sua participação foi a disponibilidade para estar presente nos encontros semanais.

Na maior parte das escolas, o grupo de alunos com o qual o professor irá trabalhar já está previamente definido, não ocorrendo nenhuma escolha de elenco. Entretanto, a seleção apontada por Spolin, através dos jogos teatrais é uma maneira interessante para as situações nas quais o professor fará algum tipo de escolha. Também podemos entender estas proposições como uma forma do professor fazer uma avaliação prévia do grupo para uma melhor estruturação de seu curso, já tendo em conta as características dos integrantes.

Spolin apresenta a importância do diretor ser alguém que dê energia para o grupo, inspirando-os para atuar, através do foco e das instruções. Propõe a não realização de ensaios quando o diretor está sem energia, cansado ou entediado, substituindo a atividade por um jogo tradicional ou por uma leitura de mesa encaminhada pelo assistente.

Dentro da situação escolar curricular, quase nunca o professor terá um assistente a quem solicite o acompanhamento dos trabalhos em momentos de cansaço. Entretanto, embora a situação seja bastante diferenciada das características sugeridas, é importantíssimo que o professor dê ouvidos a esta recomendação e não trabalhe de forma a ser um desestímulo ao processo e ao grupo. As soluções possíveis não serão as mesmas apontadas por Spoli, porém se mantém o fundamento, adequando-se à nossa realidade profissional.

Quanto à escolha da peça, são apontados alguns aspectos ao definir qual peça será montada, tais como: para quem se dirige, se é um texto adequado ao grupo que 
irá trabalhar, se será possível monta-la, se é um texto que irá possibilitar uma experiência criativa, etc. Não é feita nenhuma menção a textos que não sejam teatrais.

O diretor deve deixar que o tema apareça, evitando que a ansiedade em encontrálo faça que um tema qualquer se imponha ao trabalho, fechando caminhos possíveis.

O tema é o fio que costura e tece cada pulsação da peça ou da cena. Ele se entrelaça e se mostra no mais simples gesto do ator e nos últimos detalhes do figurino. (Spolin, 1999:29)

A escolha do texto que seria trabalhado com o grupo de teatro Pé Sujo partiu do meu interesse em investigar as possíveis relações entre o conto e os jogos teatrais. Pupo nos mostra a importância que outras formas literárias vêm tomando nas montagens teatrais.

Entre as tendências contemporâneas da encenação, é possível observar uma relativização da supremacia da peça teatral. O ponto de partida das montagens vem se diversificando nitidamente: outros tipos de textos, não somente dramáticos, mas também líricos e épicos passam a dar origem a espetáculos teatrais. Adaptações de contos, lendas, romances, poesias, constituem freqüentemente a motivação da qual partem grupos e diretores. (Pupo, 1997:2/3)

Embora a escolha do conto a ser trabalhado já estivesse previamente definida, este foi entendido como propulsor do trabalho e, conforme exposição no primeiro capítulo desta dissertação, a temática explorada foi definida no desenvolver dos jogos.

As técnicas teatrais são propostas aqui dentro da perspectiva da necessidade, isto é, ao identificar quais as necessidades do ator, se buscará uma técnica que vá de encontro às mesmas, deixando claro para o ator as muitas maneiras possíveis de fazer e dizer algo.

O diretor ajuda os atores a encontrar e manter o foco, o qual coloca o jogo em movimento, e todos se tornam parceiros de jogo na medida em que prestam atenção aos mesmos problemas a partir de diferentes pontos de vista. Dessa forma, através do foco entre todos, dignidade e privacidade são 
mantidas e a parceria verdadeira pode surgir. Confie no foco! Deixe-o trabalhar para você. (Spolin, 1999:22)

A definição de foco está apresentada no livro, de acordo com sua função no jogo teatral, deixando clara a importância do mesmo para que os jogadores possam encontrar a espontaneidade e a cumplicidade com os demais. A espontaneidade é desejada e temida pelos atores, já que provoca desequilíbrio, pois estarão entrando em contato com formas desconhecidas de agir.

A possibilidade de nos aproximarmos da espontaneidade se dará desde que sejam criadas condições para que os jogadores tenham tranqüilidade suficiente para o questionamento de suas estruturas definidas de ação. Cortela nos fala sobre a dificuldade em provocarmos mudanças:

Os valores que criamos produzem uma "moldura" em nossa existência individual e coletiva, de modo a podermos enquadrar nossos atos e pensamentos, situando-os em uma visão de mundo (uma compreensão da realidade) que informe (dê forma) os nossos conhecimentos e conceitos (nossos entendimentos); é a partir dos conceitos que guiamos nossa existência e, de uma certa forma, porque antecedem nossas ações, são também os nossos conceitos prévios, nossos preconceitos (pré/conceitos). Entretanto, valores, conhecimentos e preconceitos mudam porque humanos devem mudar; como vida é processo e processo é mudança, ser humano é ser capaz de ser diferente.

É por essa razão que, quando enfrentamos alguém no campo dos seus valores e preconceitos, a reação é forte; não estamos confrontando apenas idéias e sim pontos de apoio de sua existência e de sua segurança na vida, isto é, nós podemos estar ameaçando os pilares sobre os quais se sustenta sua própria identidade." (Cortela, 2001:46)

A clareza de proposição que o foco traz, possibilita um equilíbrio para o jogador que está se lançando neste universo novo.

É importantíssimo que a avaliação do trabalho se distancie da perspectiva de aprovação/desaprovação, o que será conquistado quando avaliamos o que foi feito, se o foco foi mantido e o problema solucionado. Esta maneira de avaliar fará com que o diretor assuma a posição de guia do grupo. 
A instrução busca orientar o jogador, mantendo o contato entre jogadores e diretor, sendo um gerador do processo de jogos teatrais.

A instrução deve ser livre do tom autoritário. Ela não é diretiva. É uma instigação, provocação, estímulo através dos quais o instrutor-diretor catalisa a energia do jogo. Para dar instruções, utilize um comando simples e direto: Compartilhe o quadro de cena! Veja os botões da camisa de João! Compartilhe a sua voz com a platéia! Contato! Veja com seus pés! Não conte uma história! Ajude o seu parceiro que não está jogando! (Spolin, 1999:25)

Nas instruções para atuar a autora define Deixa de Texto e Deixa de Ação, mostrando a possibilidade de que ambas estejam colocadas no texto que 0 ator receberá, porém sem indicações por parte do diretor sobre a forma como o ator deverá agir antes do segundo período de ensaio, quando já terá explorado diversas soluções para as cenas.

No primeiro capítulo observamos que a autora trabalhou com os Eixos de Aprendizagem do sistema de jogos teatrais, definindo o foco, a instrução e a avaliação quanto ao papel que ocupam não apenas no jogo teatral mas também no processo de montagem de uma peça de teatro. As regras estão presentes na apresentação dos jogos.

Em todos os conceitos são apresentadas maneiras como o diretor deverá agir para o encaminhamento do trabalho, que postura adotar na relação com o grupo e nas escolhas necessárias para o encaminhamento dos ensaios.

Nos capítulos seguintes será proposta a divisão dos ensaios em três períodos. É sugerido que se considere o "tempo do relógio" e da "energia para a organização dos ensaios", tentando manter todos os atores ocupados todo o tempo e uma atmosfera relaxada. 


\section{OFICINAS}

No segundo capítulo, intitulado Oficinas, são propostos jogos para acontecerem no decorrer dos ensaios, antes e durante, conforme as necessidades que o grupo apresente. Os jogos irão trabalhar com o conceito de olhar. A idéia de olhar, aqui colocada, inclui uma postura do ator/jogador de entrar em relação com os demais jogadores. Neste sentido o olhar significa realmente ver o que olhamos, entrar em contato com o que olhamos.

Partindo da idéia do olhar como uma forma de estabelecer contato, entendi este momento definido por Spolin como Oficinas como o período no qual o grupo de alunos estabelecerá um relacionamento suficiente para se reconhecer como tal, além de conhecer diversos conceitos apresentados nos jogos. Nas respostas dadas para as perguntas Como foi a formação do grupo? Você acha que os jogos teatrais colaboraram para que ele se formasse? podemos observar a importância que os jogos tiveram neste processo:

Com certeza os jogos tiveram uma super importância, eles fizeram com que a gente se inturmar. Mariana

Sim pois no decorrer das reuniões alguns foram saindo de forma que o grupo foi tomando uma forma legal além também com os jogos onde o grupo foi se unindo numa redoma onde éramos imbatíveis. Edmilson

Com certeza, sem os jogos ninguém ia se conhecer tão bem, ter tanta intimidade, saber o que o outro "quer ser". Tudo isso. O JOGO É TUDO! Priscila

Através de uma professora de teatro que, no seu mestrado, tinha de apresentar esse trabalho. Sim, pois dão mais proximidade das pessoas nos jogos. Daniel

Os jogos foram importantíssimos na formação do nosso grupo. A sua formação foi a mais natural possível! Fomos nos conhecendo aos poucos e através dos jogos fomos nos aproximando mais também fora do grupo. Solange 
A formação do grupo foi muito boa, o os jogos ajudaram para que nos relacionássemos melhor uns com os outros, eu acho que a unir o grupo mais rápido. Giovani

No decorrer dos encontros pudemos explorar através dos jogos a necessidade dos jogadores entrarem em contato com os seus parceiros para que o jogo acontecesse. No nosso quarto encontro pedi que os alunos escrevessem algumas palavras-síntese referentes ao encontro anterior. Um dos participantes escolheu a palavra solidão, o que gerou um questionamento por parte dos demais integrantes.

$\mathrm{Na}$ explicação sobre a escolha, o aluno disse que em alguns momentos ele ficava "viajando", pensando em coisas só dele e dessa forma se sentia sozinho. Este posicionamento possibilitou a discussão do grupo de que o trabalho teatral é um trabalho de relação, que enquanto jogamos, estamos atentos aos parceiros, estamos juntos.

No final do período entendido como o de Oficinas, o grupo escolheu um nome para si: Grupo de Teatro Pé Sujo. Esta escolha se deveu ao fato de ficarmos todos com os pés sujos após os encontros, já que tirávamos os sapatos no início da aula. A necessidade de definir um nome para o grupo, denota o reconhecimento do grupo como uma unidade.

Além dos jogos teatrais propostos por Spolin também trabalhamos com jogos tradicionais. Inicialmente os jogos foram propostos por mim mas aos poucos os alunos trouxeram sugestões que foram incorporadas ao trabalho.

Quanto aos aspectos da linguagem teatral, é possível identificar, tanto através dos relatos como da avaliação nos momentos de jogo, a assimilação da estrutura dramática e dos eixos de aprendizagem propostos por Viola Spolin.

No que se refere ao Onde, o grupo pode identificar a existência de um espaço de jogo, conseguindo interagir no que diz respeito ao espaço imediato e geral. Os jogos 
que trabalharam com a manipulação de objetos (figura 12) e a movimentação pelo espaço de cena definido pelo grupo, fizeram com que estas duas dimensões do espaço ficassem claras.

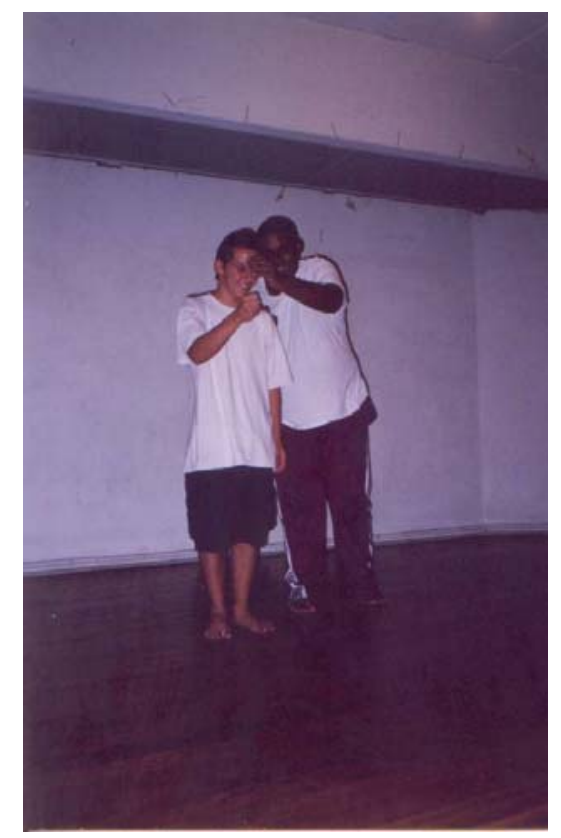

Figura 12: Jogo Dificuldade com pequenos objetos

Quanto ao Quem, observo que o principal ganho foi a percepção corporal possibilitada através dos jogos e dos aquecimentos/relaxamentos. Ficou evidente a importância da fisicalização através do domínio corporal e de sua exploração. Não trabalhamos a existência de personagens em uma criação mental, desta maneira as transformações se deram na transformação do próprio corpo, seja na forma de se apresentar ou na forma de se movimentar, no gestual de cada um.

Quanto ao terceiro aspecto da estrutura dramática, o $O$ Que, percebo que já foi possível a compreensão de que nos jogos, assim como nas cenas, existe uma ação.

Os Eixos de Aprendizagem foram incorporados ao processo de trabalho, desta forma: a Instrução, o Foco, a Avaliação e as Regras participaram permanentemente do nosso cotidiano, sendo incorporados e compreendidos como forma de realização do 
trabalho. Dentro desta estrutura, fica evidente a resolução de problemas através do Foco.

Um aspecto importante para o trabalho, que é comentado por quase todos os alunos em suas reflexões sobre o aprendizado que o curso possibilitou até então, é o da imaginação/criação. Ressalto aqui sua importância, pois observo que é na possibilidade de exploração de soluções novas, seja pela combinação de fatores entre os vários participantes, seja na utilização de respostas inusuais, individualmente é que se dá o reconhecimento da criatividade por cada um dos participantes.

O fisicalizar, o tornar presente e o se permitir acreditar no que é visto, cria um espaço imaginário que amplia enormemente as possibilidades do jogo. Observo que esta criação de um espaço imaginário, assim como do encontro de soluções criativas para as propostas feitas, faz com que cada participante tenha uma relação extremamente prazerosa com o trabalho, sendo assim um dos aspectos mais comentados pelo grupo. Vivencia-se assim uma possibilidade que está além do domínio teatral, que pode ser resgatada nas muitas situações e relações da vida de cada um.

O relato escrito pela Solange exemplifica diversos dos aspectos aqui apontados:

Eu aprendi muitas coisas com o curso de teatro até agora, uma delas foi supervisionar o meu desempenho em relação a trabalhos em grupo.

A convivência com pessoas diferentes tem me ensinado que pelo fato de termos opiniões diferentes não quer dizer não possamos nos empenhar em busca de um objetivo comum. E este fato nos acompanhará durante toda a nossa vida por isso a importância de estarmos convivendo e aprendendo com pessoas que vêm o mundo do seu jeito e conseqüentemente nos ajuda a obter conhecimento a partir desta visão.

O curso tem trabalhado também a nossa imaginação fazendo com que nos colocamos em situações imaginárias. E ao procurar solução para sair destas situações trabalhamos também a nossa capacidade para resolver as coisas. Em fim, o curso tem me ensinado coisas que pretendo usar no palco e na vida. 


\section{O PRIMEIRO PERÍODO DE ENSAIO}

No terceiro capítulo, intitulado O Primeiro Período de Ensaio são apresentadas várias maneiras pelas quais o diretor poderá iniciar o trabalho de ensaios e a aproximação com o texto.

A primeira questão levantada é a importância em se acreditar no elenco com o qual se trabalhará. No decorrer de todo o capítulo são apresentados jogos que buscam a relação do grupo, seja entre os participantes, seja com a platéia ou com o texto. Além dos jogos para ensaio, os aquecimentos são apontados como um importante momento para que o grupo elimine diferenças e trabalhe conjuntamente, possibilitando que cada integrante faça parte do todo.

No trabalho com o grupo de teatro Pé Sujo a realização de aquecimento no início dos encontros e de relaxamento no final foi fundamental. Iniciávamos as aulas com uma roda onde era lido o protocolo $^{33}$ referente ao encontro anterior e comentávamos as impressões de cada um. Os aquecimentos foram, na maior parte das vezes, realizados com jogos tradicionais, que são considerados por Spolin como importante elemento a ser incorporado ao processo, não apenas no momento do ensaio, mas em todo o trabalho realizado.

Os relaxamentos tinham como enfoque uma maior consciência corporal por parte de cada um dos participantes, a ampliação do repertório de movimentos e a integração entre eles. Podemos observar, no depoimento do Edmilson, a importância dada à estes momentos, pela falta que fizeram quando nos excedemos no tempo destinado ao jogo, inviabilizando a possibilidade de acontecer o relaxamento: $\mathrm{Na}$ última aula nós conversamos sobre nós estarmos meio frios na aula, vimos que a falta do relaxamento no final das aulas estava nos prejudicando. Resolvemos que não mais deixaríamos de fazer o exercício.

${ }^{33} \mathrm{O}$ uso do protocolo como forma de registro e reflexão sobre o trabalho será discutido no terceiro capítulo. 
O primeiro período de ensaio é o momento no qual o grupo entrará em contato com o texto. Para este contato inicial, Spolin propõe diversos jogos que possibilitam uma relação com o texto que seja de ruptura na forma tradicional de leitura. Os jogos possibilitarão variedade na fala e, com isso, uma amplitude de significados atribuídos ao texto.

O primeiro contato que tivemos com o conto que trabalhamos foi no sétimo encontro do grupo e deu-se inicialmente com a narrativa do mesmo feita por mim, conforme explicado no primeiro capítulo.

Partimos então para um processo de apropriação do texto, buscando as diferentes abordagens que o mesmo poderia sugerir, através de jogos que trabalharam especificamente com o texto escrito. Jogamos: Soletrando, Vogais e consoantes e Câmera lenta ${ }^{34}$. O grupo ficou bem envolvido com as propostas e explorou diferentes formas de falar o texto. Foi evidente a descoberta que estes jogos propiciaram, tanto para os vários significados que a narrativa pode comportar, como para a multiplicidade na fala. Os jogos abriram diferentes perspectivas para 0 entendimento do conto.

O primeiro momento que o grupo narrou o conto coletivamente foi com a utilização dos três jogos já citados e o uso de uma bola. $O$ jogador que estivesse com a bola na mão estaria lendo o texto. A bola poderia ser jogada para qualquer outro participante que então passaria a ler o texto, ou algum dos jogadores poderia retirar a bola do leitor e assumir a função. No meio da leitura incluí a possibilidade de que um jogador se somasse ao que estivesse lendo e fosse feita uma leitura conjunta. No final da narrativa somamos à proposta a exploração de intenções de fala, conforme sentimentos que a narrativa sugerisse. Este jogo foi incluído na montagem da peça, ao

\footnotetext{
${ }^{34}$ No jogo Soletrando todas as palavras devem ser soletradas, com o objetivo de que elas se mantenham vazias de significado. O jogo Vogais e consoantes focaliza as vogais ou as consoantes, possibilitando a familiarização com a estrutura fisiológica da língua. No jogo Câmera lenta os jogadores devem ficar em câmera lenta enquanto lêem o texto, com o objetivo de estarem todos no mesmo lugar.
} 
trabalharmos a cena 12. Retomamos o jogo com um lenço, com as duas narradoras passando o lenço uma para a outra antes de falar.

Entendo que a aproximação ao conto através do jogo foi o que permitiu que a estória trabalhada não fosse mantida na apreensão cerebral. Koudela nos fala da importância da "corporificação" para que surja a espontaneidade:

Spolin estabelece uma diferença entre inventividade e espontaneidade. Ao trabalhar apenas com a associação de idéias (estória), o jogo de improvisação permanece ainda no plano cerebral. A ação espontânea exige uma integração entre os níveis físico, emocional e cerebral. Em oposição a uma abordagem intelectual ou psicológica, o processo de jogos teatrais busca o surgimento do gesto espontâneo na atuação, a partir da "corporificação". (Koudela, 1990:51)

Após esse primeiro período de exploração do conto no qual trabalhamos a apropriação da narrativa, explorando diferentes leituras possíveis para a mesma, exploramos o Onde, o Quem e o O Que ${ }^{35}$, retomando jogos que já haviam sido feitos no período entendido como Oficinas.

Neste momento, após a exploração da estrutura do jogo relacionada ao conto, pude notar que o domínio da narrativa já era bem grande, sendo possível desmembrála e escolher o ponto de vista a ser enfocado. No depoimento da Mariana pode-se observar a relação estabelecida entre a idéia de personagem e a exploração dos mesmos através dos jogos: Bom, nessa aula descobri que se mudarmos alguma coisa em nós, a voz, o jeito de andar, qualquer coisa que não seja característica nossa estaremos colocando vida no personagem, deixando-o mais completo como tem que ser.

O trabalho com o O Que foi desenvolvido com os jogos Dar e Tomar, Jogo de Orientação 1 e 2 e Convergir e Redividir ${ }^{36}$. Neste último, o grupo teve uma dificuldade

\footnotetext{
${ }^{35} \mathrm{O}$ trabalho com o onde e o quem foi detalhado no primeiro capítulo.

${ }^{36}$ No jogo Dar e tomar, apenas um jogador se movimenta em cena, ele poderá dar a possibilidade de movimento para outro ou algum dos demais jogadores podem tomar, tem como objetivo promover a
} 
muito grande em atuar coletivamente. Ficou uma bagunça geral, sem que fosse possível entender o que se passava na cena. Os jogadores passaram todo o tempo tentando encontrar formas de tornar as cenas compreensíveis e, na avaliação, comentaram a dificuldade de interagir. Houve muita reclamação em relação à atitude de um dos jogadores, que chorava muito alto em uma das cenas propostas e não deixava que mais ninguém fosse ouvido. Comentamos que os demais não souberam propor a partir do jogo que estava se estabelecendo, jogando com definições prévias do que era o mais importante. Ficou evidente a dificuldade em jogar, alterando a ação imaginada previamente ou presente na narrativa, quando esta ação não está dentro da expectativa.

Existe uma grande dificuldade em trabalhar com todo o grupo, em uma cena coletiva. A solução encontrada pelos jogadores para lidarem com essa dificuldade foi tentar se sobrepor aos demais, de tal forma que a própria ação fosse percebida, acreditando que assim os demais jogadores se submeteriam a essa "ação prioritária". Porém todos os participantes tentaram a mesma solução o que gerou uma confusão completa. Essa dificuldade fica evidente no depoimento da Priscila: Foi difícil todo mundo no palco, foi engraçado porque foi a primeira vez que isso aconteceu. Interação de duas duplas no palco foi super legal e diferente.

Os jogos propostos para trabalhar essa dificuldade de interação do grupo foram Dança das cadeiras ${ }^{37}$, seguido de Quadro de cena ${ }^{38}$. Nestes dois jogos o grupo teve que se perceber como um todo, em Quadro de cena encontraram formas variadas de ocupar o palco. Ao retomarmos Convergir e Redividir a dificuldade inicial já havia sido superada.

\footnotetext{
relação entre os jogadores. Nos jogo de Orientação 1 um jogador propõe uma ação que deverá ser feita por cada um dos participantes que entrar no jogo e no 2, o primeiro jogador propõe uma ação e os demais entrarão no jogo com ações pertinentes ao espaço onde esta ação poderia ser feita. No jogo Convergir e Redividir o foco de ação é igual ao Dar e Tomar porém é feito com grupos, que deverão, conforme a orientação do coordenador, convergir todas as ações ou dividi-las.

37 Jogo tradicional no qual todos os participantes dançam em volta de cadeiras dispostas lado a lado, no momento que a música para, o participante que não conseguir sentar fica de fora do jogo. Em cada rodada existe uma cadeira a menos do número de participantes.

${ }^{38}$ Já descrito no cap. 1
} 
As ações do conto ficaram claras através dos jogos e ao fazermos uma lista das ações que aparecem, observamos que muitas delas se repetem, além de algumas poderem ser englobadas por outras mais abrangentes. Essa ponderação já havia sido feita na primeira vez que jogamos o Jogo de Orientação 1. A lista das ações definida pelo grupo foi:

- Ganhar presente

- Se arrumar

- Roubar

- Ficar chateada

- Adoecer

- Convocação

- Tentativa de animar

- Observar

- Descobrir

- Transformar

- Adorar

- Revelar

- Conferir

- Descobrir

- Surpreender

- Sacrificar-se

- Desprezar/Abandonar

- Doar

- Transformar

- Construir

- Investigar

- Apaixonar-se

- Desprezar

- Propor (em casamento)

- Adoecer 
- Revelar

- Reconciliar-se

- Casar.

A compreensão dos conceitos da estrutura dos jogos se evidencia nas respostas dadas pelo Daniel à pergunta $\mathrm{O}$ que é onde, quem e o que no jogo teatral?

Nos jogos teatrais o "onde" é o lugar tanto fora como dentro do ambiente "em que estamos", o quem somos nós representando algo que seria o "que".

\section{Daniel}

Ao conversarmos sobre a possibilidade de fazermos uma peça sobre o conto "O Pássaro Verde", houve um primeiro posicionamento dos alunos de que o número de cenários necessários seria excessivo. Questionei o grupo se o fato de não utilizarmos nenhum tipo de cenário quando jogamos, nos impedia de vermos o que se passa nas cenas. Foi muito interessante observar no grupo a descoberta da possibilidade de não trabalhar com um cenário realista. No momento que isto ficou claro, todos deram sugestões sobre como poderíamos trabalhar e quais as formas de construir as cenas, quanto ao cenário, figurino, iluminação e sonoplastia.

A estética realista é evidentemente o repertório dominante dos alunos. A principal referência é a da televisão, mesmo para os alunos que já foram ao teatro. Dessa forma, o repertório do qual eles podem lançar mão é restrito, sendo muito grande a dificuldade em imaginar possibilidades que não sejam de uma reprodução realista de cada um dos espaços.

Após esta conversa sobre as resoluções para uma montagem do conto $O$ Pássaro Verde definimos que seria com o conto que faríamos a peça. Esta definição ocorreu no décimo quarto encontro do grupo, no dia seis de junho. Apesar do meu interesse de que trabalhássemos com este conto até o fim, contava com o risco do grupo não se envolver com esta história, porém não foi o que ocorreu. $O$ interesse no conto permaneceu e continuamos por mais dois encontros trabalhando jogos que estabeleceram relações do conto com o mundo atual. 
Trabalhamos alguns jogos que são sugestões dadas por Spolin para o momento de Afinações, pois me pareceu necessária a antecipação destes para o momento definido por primeiro período de ensaio. 0 jogo Sombra ${ }^{39}$ deixou evidente que a diferença corporal entre os jogadores não é um impedimento para que a sombra ocorra, sendo fundamental que os dois estejam com o foco presente, mostrou a possibilidade da semelhança mesmo quando a aparência física é tão diferente, como pode ser observado na figura 13 , abaixo.

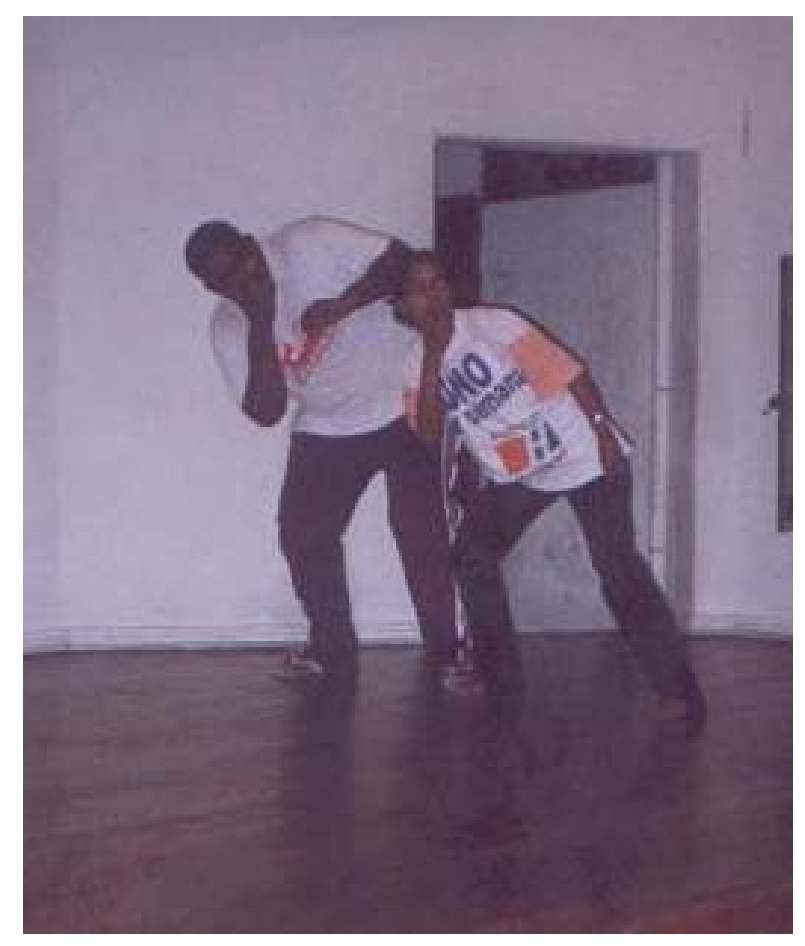

Figura 13: Sombra

A percepção da possibilidade de semelhanças entre os jogadores, mesmo quando o físico de cada um é tão diferente, vem de encontro a visão de que o personagem não precisa ser realizado pelo ator que mais se assemelhe a ele em suas características físicas, conforme esclarece Pupo:

\footnotetext{
${ }^{39}$ Neste jogo o grupo é dividido em dois times, um deverá fazer sombra ao outro.
} 
Essa flexibilidade na relação entre o número de jogadores e o número de personagens constitui uma riqueza fundamental no processo de desenvolvimento da capacidade de jogo. Aquela visão tradicional de um tipo de teatro, segundo a qual cada papel deve ser preenchido por um ator cujas características físicas de preferência correspondam o mais possível às do personagem, é assim profundamente questionada. Ela passa a ser considerada como apenas uma entre as múltiplas possibilidades de representação. (Pupo, 1997:94)

Com o jogo Começo e Fim com objeto, no qual cada jogador deve compartimentar a fisicalização de um objeto falando começo e fim para cada uma das partes, houve uma certa dificuldade em identificar o início e o fim de cada parte da ação. Porém o jogo fez com que cada um dos jogadores e nós, na platéia, pudéssemos visualizar o objeto com muito mais precisão, todos os objetos se tornaram presentes na gestualidade obtida pela compartimentarização da ação.

Identificamos no sistema de jogos teatrais a possibilidade de trabalhar com o significado do gesto. O processo se fundamenta no jogo e na ação improvisada. O que diferencia o método é a seqüência gradual de problemas solucionados, que levam não apenas à liberação da ação lúdica mas também à decodificação da estrutura da linguagem. (Koudela: 1990:43)

O cantar também foi trabalhado intensamente, tanto por ser incluído em alguns jogos, aquecimento e relaxamento como por termos feito toda a narrativa do conto cantando. No depoimento de Sidnéia observamos a importância dada à esta atividade: Eu adorei a forma que fizemos relax uma maneira bem diferente cada um cantando uma música até deitar. O mais legal é que ficamos até mais do horário combinado cantando. Está tão bom ver todos reunidos fazendo tudo juntos.

Neste mesmo momento o grupo manifestou a necessidade de começarmos a trabalhar com a perspectiva da peça mais clara, texto definido e divisão de personagens também. Conversamos sobre como se daria este processo e ficou decidido que no primeiro encontro após as férias de julho eu traria uma adaptação do conto para teatro e então definiríamos os personagens. Isto ocorreu no penúltimo encontro antes das férias. 
No último encontro do semestre, levei todas as fotos tiradas até aquele dia e retomamos os encontros através das fotos. Cada um dos alunos escolheu uma foto e propôs um jogo a partir dela. Vendo as fotos, cada aluno deveria identificar qual o jogo que estava sendo feito no momento que foi fotografado e propor para os demais a sua realização.

Os jogos escolhidos foram:

$1^{\circ}$ - Sombra

$2^{\circ}$ - O que estou comendo? ${ }^{40}$

$3^{\circ}$ - Jogo da bola. ${ }^{41}$

$4^{\circ}$ - Um só espaço, o mesmo personagem e uma ação para cada jogador.

$5^{\circ}$ - Modelagem do personagem.

$6^{\circ}$ - Convergir e Redividir.

$7^{0}$ - Pega-pega de animal, feito com caracterização corporal e vocal.

Após as férias de julho, voltamos ao trabalho comentando sobre os conceitos incorporados ao trabalho no decorrer do primeiro semestre. Pedi que cada aluno relembrasse um jogo que não se relacionasse com o conto e outro que houvesse sido feito partindo do mesmo.

Na retomada dos jogos ficou muito clara a importância dada à instrução e à avaliação dentro de todo o processo. O grupo comentou o quanto eu orientava o desenvolvimento dos jogos na apresentação da proposta e através dos comentários feitos no seu decorrer. A avaliação não foi vista como um julgamento do trabalho que tivesse parâmetros de certo e errado, mas sim como uma forma de refletirmos sobre o ocorrido e sobre a manutenção do foco. Esclarecemos o conceito de foco através da retomada da maneira como os jogos foram apresentados e das orientações no decorrer dos mesmos.

\footnotetext{
${ }^{40}$ Neste jogo o grupo é dividido em dois e cada um escolhe uma comida para comer. A parte do grupo que permanece como platéia deverá observar as características das ações dos jogadores, que irão fisicalizar o ato de comer o que foi escolhido.

${ }^{41}$ Cada grupo escolhe uma bola e em um semi-circulo, joga-a entre os jogadores. A bola deve tornar-se real pelo contato dos jogadores com ela e entre si.
} 
A noção de espaço, personagem e ação estava bastante clara para todo o grupo. Retomamos os jogos feitos e a compreensão destes conceitos, assim como a relação dos mesmos com a montagem da peça.

Esclareci a importância de todos estes conceitos para o trabalho que iniciaríamos, observando que seria esta a nossa forma de trabalhar a montagem da peça.

Apresentei para o grupo o roteiro das cenas da peça $a^{42}$ baseado no conto e criado a partir das prioridades estabelecidas por todos. O roteiro apresentou cada momento do conto, com cada ação definida em uma cena. Os personagens incluídos nas cenas também foram definidos no roteiro.

A ansiedade para definirmos os personagens estava grande, mas expliquei que só faríamos a divisão dos personagens após a realização dos jogos propostos para cada uma das cenas. Cada jogador fez o personagem que queria, independentemente do sexo do ator/personagem.

No capítulo 1 deste trabalho foram apresentadas diversas cenas associadas aos jogos, que influíram na definição do texto dramático. A seguir relato as cenas que definiram aspectos da montagem no que diz respeito à atuação e não somente ao texto.

Para a cena 6, na qual o pássaro rouba o pente da princesa, foi proposto que todos os movimentos fossem feitos em câmera lenta. A lentidão explorada neste jogo foi incorporada ao momento em que o pássaro rouba a fita da princesa, após o roubo, tanto o pássaro como a princesa se movimentaram em câmera lenta.

\footnotetext{
${ }^{42}$ Ver apêndice 2.
} 
Para as cenas 7 e 8 , nas quais a princesa ganha a fita do rei e o pássaro a rouba, foi proposto o jogo Tensão Silenciosa ${ }^{43}$ seguido de um grito que poderia ocorrer no final do jogo quando a fita fosse roubada. Houve muita dificuldade em realizar esse jogo, o silêncio quase não apareceu, havendo pouquíssima tensão. Realizamos o jogo e foi mantida esta solução da tensão seguida do grito no final do roubo, quando encenamos este momento da estória.

Para a cena 26, na qual a princesa vai até o caixão e rejeita o príncipe com a mesma frase que ele a rejeitou, foi novamente proposto o jogo Tensão silenciosa, sendo que a única frase que deveria ser dita era a da princesa. Todos os participantes estavam em cena e, pela primeira vez, foi criada a tensão através do silêncio. O grupo explorou as expressões faciais e corporais e toda a narrativa que fazia parte da cena ocorreu em silêncio. No final da cena, o Giovani e a Priscila que faziam o príncipe e a princesa, não haviam entendido que a cena ia até o momento da reconciliação dos dois, o que fez com que se estendesse por muito tempo a rejeição dela por ele e eles acabaram perdendo a concentração. O restante do grupo reclamou muito deles rirem naquele momento, pois estavam todos muito envolvidos na cena.

No depoimento da Sidnéia observamos a intensidade do jogo acima citado: Encostamos na parede com o corpo leve e a Ale fez como se o grito estivesse vindo de baixo para cima até chegar a boca onde gritaríamos com a maior força. Eu senti como se o meu corpo inteiro tivesse gritado junto.

$\mathrm{Na}$ conversa na qual definimos as características da peça, iniciei o diálogo questionando como eles imaginavam o cenário da peça. $\mathrm{A}$ imagem apresentada era do quarto da princesa como um quarto de paredes de pedra, uma cama antiga, alta, com objetos de quartos de filmes de contos de fadas e imagens da Idade Média. Discutimos sobre como traduzir esta idéia para o palco e ficou claro no decorrer da

\footnotetext{
${ }^{43}$ Neste jogo a tensão entre os jogadores deve ser tanta que não possibilite a fala; tem como objetivo utilizar o silêncio para a construção da tensão em cena.
} 
conversa de que não existia a vontade de ter um cenário completamente naturalista, já que todo o tempo que estivemos trabalhando as cenas tínhamos o palco vazio.

Sugeri a utilização dos cubos associada a um objeto que simbolizasse o espaço da cena e essa sugestão foi imediatamente aceita pelo grupo. A minha impressão é de que esta sugestão veio de encontro às expectativas que o grupo tinha. Acredito que $o$ repertório estético dos alunos é muito pequeno, fazendo com que eles não descubram possibilidades que possam traduzir as suas idéias.

Essa situação me faz pensar que o professor é quem traz elementos e seleciona que concepção estética o trabalho terá. As relações do que trabalhamos com o cotidiano do aluno são permanentemente exploradas pelo grupo de alunos, assim como as soluções de cena, porém no momento da tradução destas soluções para o cenário, figurino, sonoplastia e iluminação do espetáculo se faz necessária a intervenção do professor.

Embora Spolin entenda o primeiro período de ensaio como o momento que vai desde o contato inicial com o texto, até a definição de todas as cenas, com as marcações pertinentes, entendi que ao chegarmos na definição do texto dramático, após a exploração dos jogos associados à cena, entravamos no momento definido como o segundo período de ensaio. A exploração das cenas através dos jogos vai de encontro à proposição de Spolin quando ela diz que o diretor deverá estar atento para que as propostas e as marcações de cena não sejam amarras impostas aos atores.

\section{SEGUNDO PERÍODO DE ENSAIO}

Em O Segundo Período de Ensaio, quarto capítulo do livro, entraremos no período de escavação da montagem. Spolin entende que, quando chegamos a este ponto, a peça estará toda marcada, os atores já saberão suas falas e os papéis estarão claros. 
No experimento realizado com o grupo Pé Sujo após a leitura da adaptação proposta por mim para o grupo, definimos quais jogadores/atores fariam quais personagens. Esta escolha foi feita levando-se em conta a experimentação do conto através dos jogos. No desenrolar do trabalho cada aluno se identificou mais com um dos personagens e escolheu o que mais tinha vontade de fazer.

Apesar desta experimentação ter possibilitado encontrarmos diversas soluções para os personagens, ainda tivemos uma escolha consideravelmente pautada em aspectos físicos, especificamente para os personagens do rei e da princesa. A referência da princesa como alguém frágil e delicada e do rei como gordo e bonachão se fez presente no momento da escolha, assim como durante todo o processo de experimentação dos jogos.

Mesmo não existindo de minha parte nenhum posicionamento que levasse a uma escolha pautada neste referencial, todos os alunos escolheram para fazer a princesa, a aluna que mais se aproximava com este perfil físico; e para o rei, o aluno que tinha esse tipo, logo ao entrar em contato com a história, declarou que gostaria de fazer este personagem (figura 14).

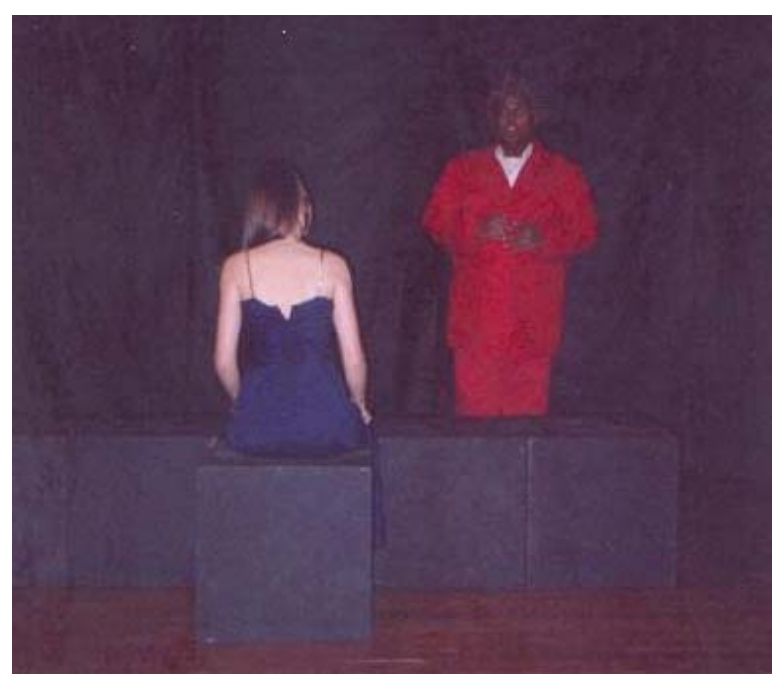

Figura 14: rei e princesa. 
Os jogadores/atores que fizeram os personagens do príncipe e da princesa não fizeram nenhum outro; os demais jogadores atuaram com dois personagens cada um. Esta definição deveu-se ao número de cenas nos quais o princesa e o príncipe estão presentes.

Os trabalhos propostos para o segundo período de ensaio tiveram o objetivo de trabalhar cada uma das cenas, de tal forma que todas elas tivessem seu começo e fim definidos e que cada uma contribuísse para a construção da peça.

Para iniciarmos o trabalho de construção de cada uma das cenas dei, para cada aluno, uma pasta/caderno. Montei essa pasta na qual havia um plástico para que o texto da peça pudesse ser guardado e folhas em branco para que cada um pudesse anotar observações de soluções interessantes para as cenas, a partir dos jogos e ensaios que fizéssemos. Retomei então todos os jogos feitos desde o primeiro encontro e, junto com o grupo, lembramos como haviam ocorrido. Cada um anotou aquele que the parecia interessante para ser utilizado para as cenas.

Spolin considera que os textos trabalhados são, de maneira geral, peças de teatro que tenham uma estrutura dramática tradicional. Em diferentes momentos do livro observamos que o enfoque dado ao texto tem em conta que os textos trabalhados serão peças teatrais, não considerando a possibilidade de serem outras as formas literárias (tampouco excluindo). Não trabalha também com a possibilidade de um texto que seja construído pelos participantes do processo no decorrer dos ensaios. Não existe nada que impeça tal opção, porém parte do pressuposto de que o texto a ser ensaiado é uma peça de teatro, previamente escolhida pelo diretor.

Na minha experiência como professora observo que nem sempre é desta forma que a escolha é feita. Muitas vezes são trabalhados textos escolhidos coletivamente, sendo que algumas das vezes esta escolha se deve a interesses da escola como um todo, seja por um tema em pauta ou por algum projeto no qual o grupo está inserido. 
Defrontamo-nos também com outro aspecto, que é o número de participantes, de maneira geral muito superior ao número de personagens das peças, o que nos obriga a fazer adaptações do original para que todos os alunos possam atuar.

O contato com o texto dramático formalizado, embora tenha sido precedido de diversos momentos de jogos e de um domínio já significativo da história, ainda foi um elemento muito limitador e intimidador. Neste primeiro contado do grupo com o texto, tendo as cenas escritas, ficou evidente o quanto a definição das falas pode ser um fator que imobiliza os jogadores para a manutenção do jogo nas cenas.

Entretanto, após uma semana de intervalo e a reflexão individual para a definição de quais jogos poderiam ser utilizados em quais cenas, o texto deixou de ser um limitador e o jogo se fez presente novamente. ${ }^{44}$ Foram trazidas sugestões principalmente para as cenas nas quais o aluno iria participar, atuando diretamente.

Este momento evidenciou o quanto o jogo estava incorporado ao processo de trabalho e à perspectiva da montagem. Parecia claro para o grupo que as cenas fossem construídas a partir dos jogos e não com uma definição prévia de minha parte, como diretora, para as ações que deveriam ser realizadas.

Fizemos todas as cenas com os textos nas mãos, porém este dado não foi um limitador para o jogo como no momento anterior. Os alunos se dispuseram a jogar e interagiram entre si, apesar da necessidade de ler as falas. $O$ texto deixou de ser o único elemento de preocupação e eles voltaram a incorporar o jogo como parte do processo de montagem das cenas.

Algumas cenas apresentaram soluções muito interessantes: a cena 8, na qual a princesa está no nicho, tanto o jogo do preso, feito pela princesa, como o do espelho e o Contato com os olhos $^{45}$, feito pelas donas de casa, possibilitaram uma grande

\footnotetext{
${ }^{44}$ No apêndice 4 estão descritos todos os jogos escolhidos pelos alunos para cada uma das cenas.

${ }^{45}$ Já explicados anteriormente.
} 
interação entre elas e com a situação da cena. Ao explorarmos esta cena, eu conversei com a aluna que fez a princesa para que ela não ficasse presa às imagens de princesas colocadas nos filmes da Disney e não tentasse, a todo momento, fazer um tipo delicado e frágil. Estas características estavam muito presentes no encontro anterior, principalmente na voz que a aluna tentava fazer. Esta observação abriu-lhe a possibilidade de entrar em contato com outras soluções, não se atando ao estereótipo de princesa como alguém frágil e incapaz. Em todas as cenas que trabalhamos, ela apareceu com uma gama de emoções e gestos muito ampliada e mais verdadeiras.

As cenas de narração foram as quais mais se explorou alterações com o texto. A aluna que fez a narradora tinha muita tranqüilidade com o texto e com o fato de atuar, e ao fazer as cenas incluiu falas que the pareciam necessárias. $O$ fato de não serem diálogos a deixou com maior mobilidade.

Na cena 15, cena do velório do príncipe (ver figura 15), a sugestão de utilizar o jogo Partes de um todo ${ }^{46}$ possibilitou uma grande interação entre os personagens que estavam no velório do príncipe como povo. Eles foram se moldando e remoldando conjuntamente, o que deu muita força para cada um. Estar em cena conjuntamente fez com que eles explorassem mais expressões para os personagens.

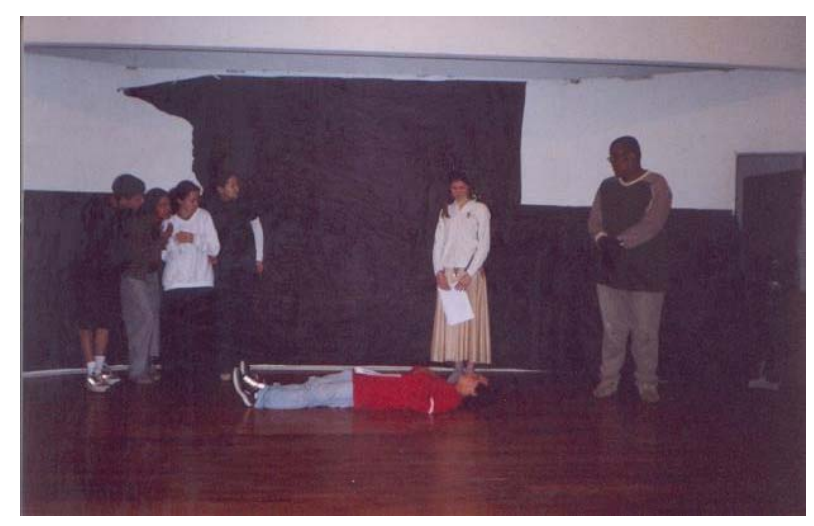

Figura 15: Velório do príncipe.

\footnotetext{
${ }^{46}$ Neste jogo cada jogador entra como parte de um todo, que poderá ser uma máquina, um objeto ou algo indefinível.
} 
No capítulo $O$ segundo período de ensaio, Spolin também ressalta a importância de serem feitos ensaios corridos e o maior número de apresentações possíveis. Para que fosse possível a realização de ensaios corridos, marcamos com o grupo um final de semana no qual passaríamos cinco horas ensaiando no sábado e outras cinco no domingo.

Como já havíamos decidido que o cenário seria composto de 6 cubos pretos, providenciei que eles estivessem prontos para este dia. A existência dos cubos criou uma nova relação com as cenas, que tomaram corpo e espaço. O que antes ficava como idéia de movimentação, agora se tornou experimentação sobre um determinado formato. O fato do espaço estar definido deu muito mais liberdade para que cada um pudesse experimentar soluções para cada um dos momentos da peça.

Nas figuras 16, 17, 18 e 19 podemos observar as diferentes posições dos cubos que criaram os cenários.

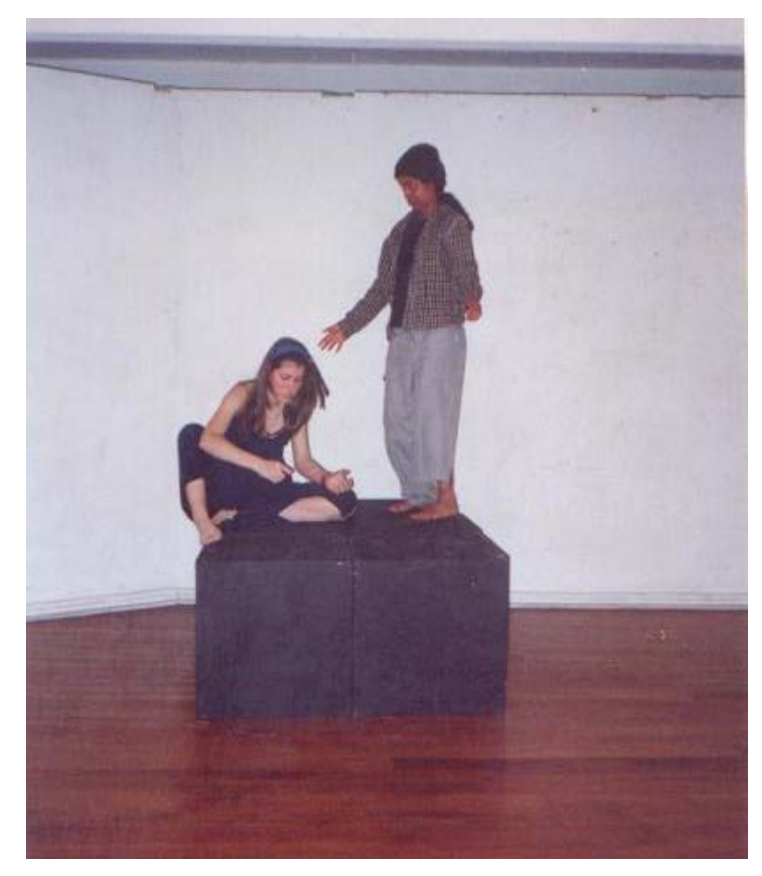

Figura16: Cubos montando a cama da princesa. 


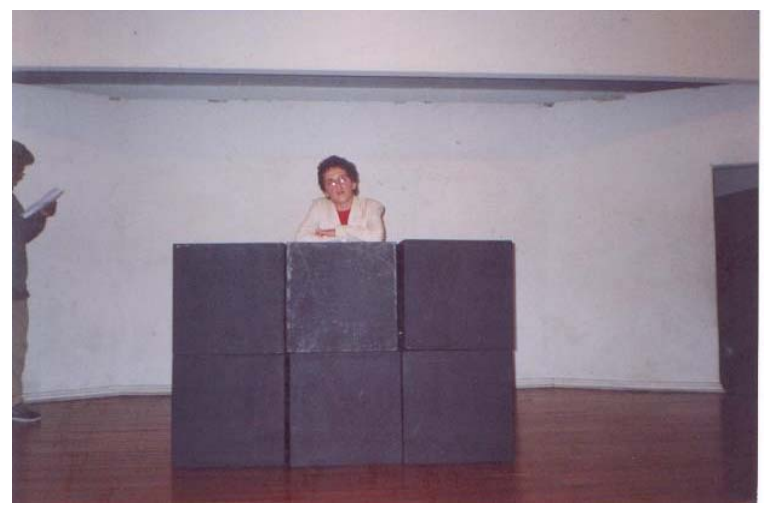

Figura 17: cubos montando a janela do príncipe.

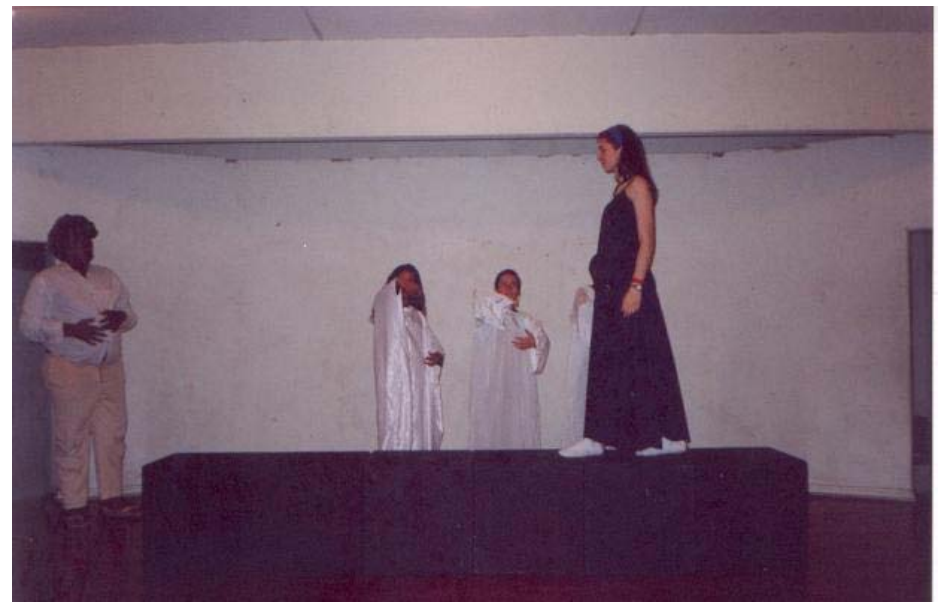

Figura 18: cubos montando a ponte de cristal.

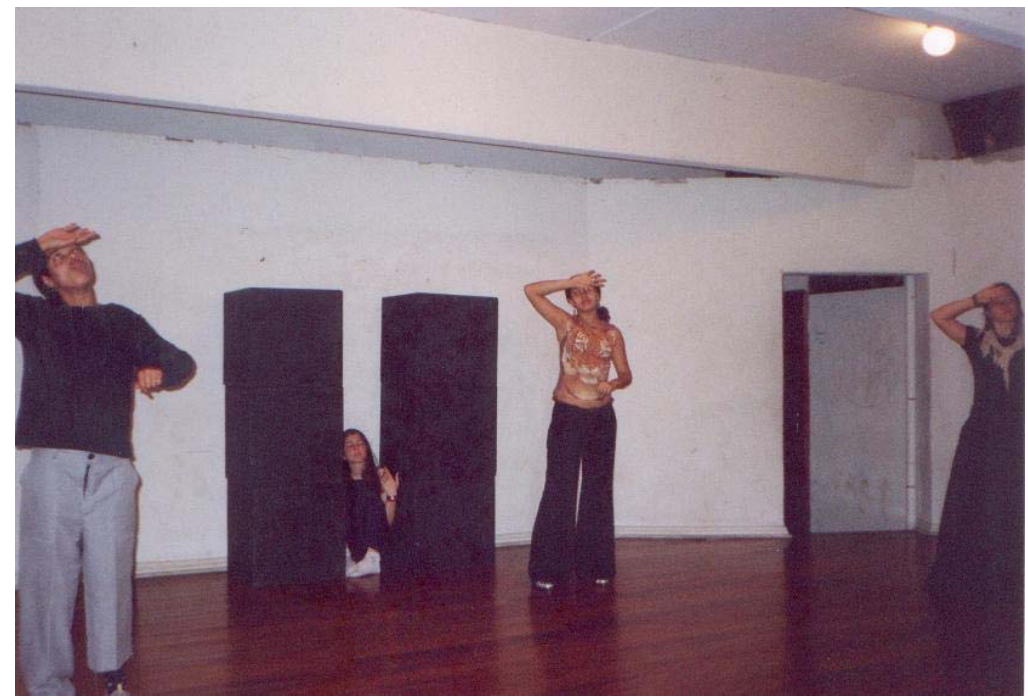

Figura 19: cubos montando o nicho. 
Nos ensaio corridos pudemos passar toda a peça e verificar como estava a seqüência e a relação entre as cenas. Embora não tenha sido possível nos determos em cada cena, pudemos observar a relação entre todas e também a maneira como o espaço foi ocupado, definindo uma unidade para toda a peça. Foi a primeira vez que também trabalhamos sem os textos. Os alunos falavam o que já tinham memorizado e quando a cena emperrava, alguém de fora dizia a fala para que ela pudesse continuar.

Os figurinos foram compostos em sua grande parte, com roupas encontradas pelos alunos. Definimos conjuntamente as características que deveriam ter e no decorrer dos encontros, cada um trouxe elementos que podiam ser utilizados. Apenas os figurinos do rei e da narradora foram confeccionados especialmente para a apresentação. A maior parte das roupas foi incorporada pelo ator/jogador, no decorrer dos encontros, pois, conforme foram encontradas as soluções de figurino, passaram, imediatamente, a ser utilizada em todos os momentos.

A maquiagem foi utilizada apenas nos dias de apresentação, já que não dispúnhamos de material para sua exploração prévia e não fizemos a opção de utilizar recursos especiais para a transformação do rosto dos atores. Manteve-se o trabalho com a expressão como base.

A sonoplastia foi sugerida por mim, em quase sua totalidade. No encontro em que fizemos o primeiro ensaio corrido, levei diversas possibilidades de músicas a serem utilizadas. Os alunos também apresentaram sugestões. A seleção de quais músicas seriam incorporadas foi feita com a experimentação em cena. Realizamos as cenas com as várias possibilidades, e a música que melhor se adequava foi escolhida.

A iluminação foi montada apenas no dia da apresentação, já que não tínhamos equipamento próprio e o custo do aluguel não nos permitia obter o material com antecedência. Devido a problemas na instalação, não pudemos fazer nenhum ensaio com as luzes, o que nos obrigou a descobrir soluções no decorrer da apresentação. 
Como a operação da mesa de luz foi feita por mim, que conhecia todos os momentos da peça, não encontrei maiores dificuldades na realização da mesma.

Dentro do possível, todos os elementos que compunham a apresentação foram incorporados ao processo de montagem, não sendo, apenas quando os recursos nos impediram.

Nas respostas dadas para a pergunta Quais as relações que você estabelece entre jogo e cena? podemos observar a importância do jogo para a construção das cenas.

Eles estão ligados, os jogos formam uma cena, que forma uma história. Mariana

Uma das relações que predomina entre jogo e cena é que ambos são determinados por um bom desempenho no palco. Edmilson

Jogo é um super exercício para se formar uma cena, sem o jogo não tem cena. Priscila

Cada jogo se encaixa em cada cena ou vários jogos ao mesmo tempo. Daniel

Os jogos teatrais ajudaram muito quando foram montadas as cenas, mas nós vimos a sua importância ao chagar no palco e usa-los para desempenhar o papel da personagem. O jogo é muito importante para que a cena corra bem e se torne mais fácil! Solange

As relações entre jogo e cena, eram feitas de acordo com as semelhanças do que ocorriam entre cena e jogo. Giovani

Neste capítulo a autora retoma a idéia de que o diretor e os atores caminham conjuntamente, não estando em disputa. Esta construção conjunta do trabalho é fortemente possibilitada pelo jogo. Gama discute esta forma de relação em sua pesquisa sobre o ensino de teatro:

Através dos jogos teatrais, cada grupo é incentivado a construir o seu processo, encontrar as suas saídas e soluções. Desta forma, o ensino de teatro desvincula-se da reprodução de técnicas, que muitas vezes são 
descobertas de outros, de um sistema de direção autoritária que não contempla o processo de criação do grupo. (Gama, 2000:41)

É também neste capítulo que Spolin ressalta a importância de ocorrerem várias apresentações, o que se diferencia do processo vivido pela maioria das escolas. Muitas vezes as apresentações são programadas para ocorrerem apenas uma vez, entretanto acredito que esta característica se deve à crença de que a apresentação não faz parte do processo de trabalho. Ao entendermos que boa parte da construção do trabalho se dará com a presença da platéia, poderemos organizar o calendário escolar de tal forma que possibilite mais do que um momento para a apresentação.

\section{AFINAC̄̃̃ES}

No quinto capítulo, Afinações, são propostos jogos que possam solucionar os problemas que surgiram no decorrer dos ensaios. A autora apresenta alguns aspectos da montagem que poderão ser trabalhados através dos jogos sugeridos.

A memorização é um problema permanente. Fica clara a necessidade de que as falas sejam memorizadas pelo processo de jogo e não no trabalho individual do ator, descontextualizado das cenas e das relações estabelecidas com os demais jogadores.

Porém, apesar da exploração pelo jogo, algumas dificuldades em dizer parte das falas se fez presente. Uma delas foi na cena do arauto, pois cada vez que ele iniciava a cena, esquecia o texto. Estava evidente que o problema não era com o texto, pois fora de cena o aluno tinha pleno domínio do que deveria dizer.

Foram feitas diversas tentativas de resolução deste problema tanto através de jogos como de conversas para identificar a razão da dificuldade. Uma das alunas comentou que isto devia estar acontecendo porque ele ficava com muita vergonha de 
ficar em tanta evidência na cena e "travava". Ele concordou com o comentário e após identificarmos a provável razão, o aluno conseguiu realizar a cena. ${ }^{47}$

O contato é outro aspecto fundamental para o trabalho. Embora este conceito já tenha sido apresentado anteriormente, assim como jogos para o seu desenvolvimento, aqui é retomado, com novas propostas de jogos e com o entendimento do papel da platéia como parte integrante da relação.

Neste momento do trabalho, a existência da platéia (não apenas a formada pelo próprio grupo mas a que existirá com a apresentação) se faz muito mais evidente. Dessa forma, o contato ocorre não apenas entre os atores/jogadores, mas também com a platéia.

Com o grupo de teatro Pé Sujo, realizamos alguns ensaios com uma pequena platéia de amigos convidados pelos alunos. A existência de pessoas de fora do processo possibilitou um entendimento ainda maior da necessidade de entrar em contato com as pessoas da platéia.

A aproximação do dia da apresentação e as preocupações com os elementos técnicos da montagem distanciavam o grupo, percebi a necessidade de retomarmos

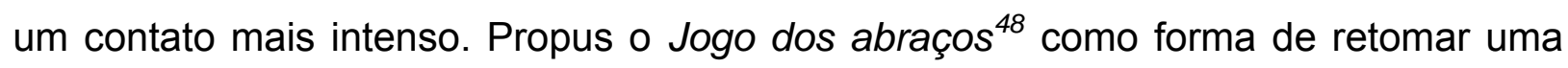
proximidade, que estava em risco de ser perdida.

No segundo dia que o realizamos o jogo, o grupo pediu que eu também participasse, o que fez com que todos se sentissem mais próximos também a mim.

\footnotetext{
${ }^{47}$ Nesta cena era o único momento que este ator/personagem ficava em tanto destaque e este pareceu ser o motivo da dificuldade nesta exposição. Além de identificarmos o motivo da perda de memória momentânea, eu, como coordenadora do trabalho, ameacei-o de perder a cena caso não conseguisse realizá-la. Discutirei esta atitude no terceiro capítulo.

48 Esse jogo foi criado por mim e consiste em dividir o grupo em duas filas. De forma aleatória os participantes irão se abraçar no meio do espaço de jogo, buscando diferentes formas de realizar o abraço. Como todos os participantes observam os abraços dados, todos devem buscar soluções que se diferenciem das já realizadas.
} 
Entendi ser necessário um contato corporal para que o contato em cena pudesse se manter. A figura 20 mostra um dos momentos de realização do jogo.

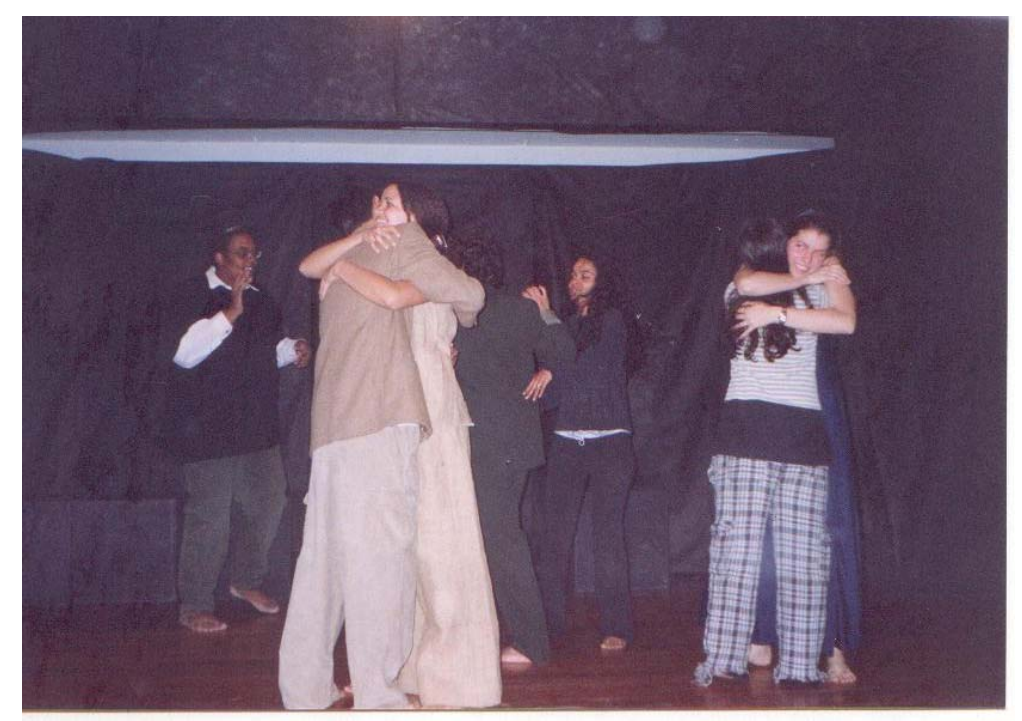

Figura 20: Jogo dos abraços.

Este jogo também foi incorporado à cena 2, quando a princesa recebe os presentes do rei, seu pai. Nesta cena existia uma enorme dificuldade de contato entre os dois atores/jogadores e o contato físico possibilitado pelo abraço ${ }^{49}$, fez com que o contato surgisse.

O silêncio também é enfocado como parte do trabalho, como um espaço dentro do qual os movimentos acontecem e que deve ser percebido pelo ator para que se aproprie dele.

Talvez a principal dificuldade do grupo tenha sido em deixar o silêncio como parte das cenas, principalmente quando o silêncio se devia a momentos de tristeza dos personagens. Fisicalizar algumas das emoções era especialmente difícil e a tristeza foi uma delas. Foi pela realização de jogos que trabalhavam diretamente estas emoções que conseguimos nos aproximar delas.

\footnotetext{
${ }^{49}$ Realizamos a cena algumas vezes com os personagens abraçados todo o tempo.
} 


\section{O TERCEIRO PERÍODO DE ENSAIO}

No sexto capítulo, O Terceiro Período de Ensaio, é quando será dado o polimento para a peça. Deve-se tomar cuidado para que o trabalho não "crie bolor", não seja tomado por desânimo e repetição desvitalizada. São apontados aspectos aos quais o diretor deverá estar atento para que isto não ocorra.

Com o grupo Pé Sujo, embora existisse um maior domínio sobre a estrutura da peça, resolvi propor jogos que não permitissem uma acomodação e conseqüente endurecimento das cenas. Realizamos o ensaio, fazendo toda a peça em blablação ${ }^{50}$. Todos acharam muito divertido, para minha surpresa, pois imaginei que pudesse existir alguma resistência. Ao comentarmos este ensaio, a opinião geral foi de que fazer a peça em blablação permitiu brincar mais com as cenas e perceber qual era a intenção de cada momento, independentemente das palavras.

Apesar do meu cuidado em propor jogos que tentassem evitar a mecanização das cenas, ela ocorreu em diversos momentos e foi a manutenção dos jogos que pode romper esta postura de domínio prévio e ruptura de relação, de presença.

Spolin aponta aqui a necessidade de que o diretor não demonstre para o grupo os seus medos com relação à apresentação e que adeqüe suas expectativas às do grupo com o qual está trabalhando.

Considero este aspecto muito importante, como a perspectiva que o professor deverá ter quando se dispuser a montar uma peça de teatro com grupos de alunos. $O$ professor deverá trabalhar a própria expectativa, tendo claro que não tem pela frente um grupo de profissionais e, portanto, não poderá exigir do grupo uma atuação a esse nível. Cada faixa etária com a qual estiver trabalhando tem suas especificidades e

\footnotetext{
${ }^{50}$ A blablação trabalha a fala sem o uso da língua, apenas com sons, buscando uma compreensão do que está sendo dito pelos demais elementos da fala.
} 
possibilidades, e o professor só poderá ficar satisfeito com o trabalho realizado quando levar em conta estas características.

Além de lidar com as próprias ansiedades e expectativas, o professor também terá que lidar com as do grupo de alunos, que já terão padrões de atuação e que, para obter a satisfação com a peça apresentada, deverão questionar estes padrões, podendo escolher e valorizar a forma teatral resultante do processo de trabalho do grupo.

Nesse capítulo também são propostas maneiras pelas quais o diretor deverá trabalhar com os elementos de figurino e maquiagem, fazendo com que ambos sejam incorporados ao processo, não deixando que sejam incorporados somente no momento da apresentação.

Quando, na situação escolar, são o professor e o grupo de alunos que assumem a responsabilidade de trabalhar todos os aspectos técnicos da montagem, por falta de uma equipe de apoio, observamos características muito diferentes na montagem de uma peça. Surgirão impedimentos para a continuidade dos ensaios, que terão que ser interrompidos e cancelados para que o grupo realize as atividades necessárias para confecção de cenário, figurino, sonoplastia, iluminação e maquiagem. Porém, embora exista o risco de se perder a fluência que os ensaios possibilitam, se contarmos com o envolvimento do grupo para a realização deste trabalho, ele estará incorporado à montagem.

Spolin entende que, no momento da apresentação, o grupo deve estar independente do diretor, sabendo se organizar sem que o mesmo fique nos bastidores. Os ensaios corridos especiais são sugeridos como forma de cortar o cordão umbilical e promover a autonomia do grupo. ${ }^{51}$

51 No terceiro capítulo deste trabalho será apresentada a maneira pela qual ocorreram as apresentações do grupo de teatro Pé Sujo. 


\section{JOGOS PARA CONTINUAČ̃̃O DOS ENSAIOS}

No último capítulo, Jogos para Continuação dos Ensaios, são apontados diversos jogos para serem realizados no decorrer dos ensaios, ressaltando-se a importância de que em todos os ensaios algum jogo teatral ocorra.

O personagem é aqui explorado por meio de muitos jogos, desde que se tenha clara a maturidade do ator para os mesmos. A construção do personagem deverá ocorrer através do jogo, nas relações estabelecidas entre os atores para que não se torne uma construção mental.

Retoma-se a importância do jogo tradicional com os quais o diretor poderá contar nos momentos que se faça necessário. São apresentados diversos jogos que trabalham os aspectos apontados, como podemos observar na lista dos jogos de cada um dos capítulos.

Teremos ainda no livro um glossário e frases para instrução, no qual são elencados trinta grupos de frases que podem ser utilizadas em grande parte dos jogos com uma explicação sobre a sua função.

Na proposta de Viola Spolin, observamos um formato de manual no qual o diretor teatral poderá se basear para a utilização dos jogos teatrais na montagem de um espetáculo. Ao organizar o livro com uma divisão de passos que o diretor deverá tomar para chegar à montagem de uma peça de teatro, a autora exemplifica uma forma pela qual o diretor poderá se apropriar dos jogos já propostos anteriormente em Improvisação para o Teatro (Spolin, 1987).

As escolhas feitas por Spolin, dentro do livro, definem sua visão sobre o que deve e o que não deve ser valorizado pelo diretor teatral e quais posturas ele deverá tomar na montagem de uma peça. 
Sendo um livro destinado ao diretor teatral, levantamos um dos aspectos que a autora propõe, que é de uma relação não autoritária para com o grupo que dirige. Esta questão se faz presente em toda a construção do trabalho proposto no sistema de jogos teatrais. Na proposição dos jogos temos uma estrutura definida pelas regras que faz com que não exista um juiz dos mesmos. Todo o grupo de jogadores tem condições de acompanhar a adequação de cada integrante do jogo, já que as regras são de domínio comum.

A avaliação, pautada no foco, também demonstra esta mesma postura não autoritária por parte do diretor, já que estará baseada na observação do que ocorreu no jogo, se o foco foi mantido e as regras respeitadas, não ficando como referência o bom ou o mau desempenho.

Em todos os momentos do processo de ensaio, desde a escolha da peça e do elenco, são pontuadas atitudes que propõem para o diretor uma postura de cumplicidade, de trabalhar conjuntamente com o grupo de atores.

Spolin em Improvisação para o Teatro (Spolin, 1987) apresenta conceitos e jogos que podem ser utilizados em uma montagem, porém, o livro ora analisado tem a qualidade de orientar o diretor na seleção dos jogos e na postura a ser tomada no processo de montagem.

É um livro que possibilita o estabelecimento de relações entre os jogos e os vários momentos de uma montagem, clarificando os passos deste caminho e abrindo possibilidades de resgate de outros jogos propostos nos demais livros da autora. 


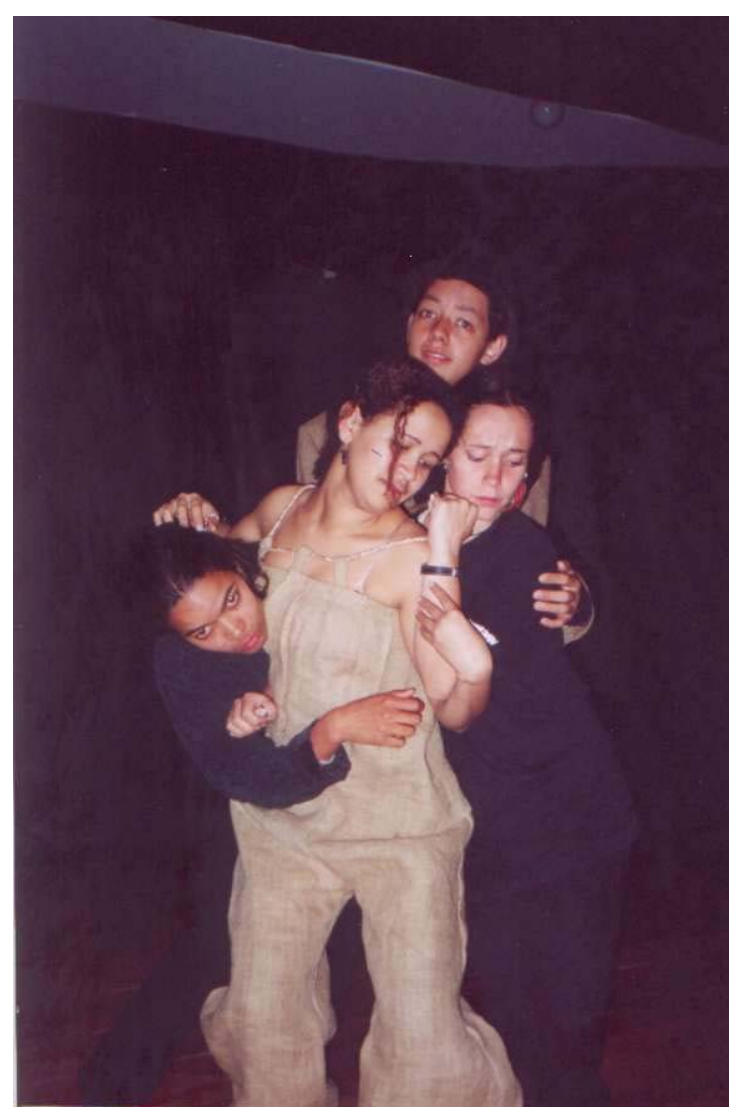

Lapidar minha procura toda de me lapidar nesse momento agora de me recriar de me gratificar buscando alma e então.

Milton Nascimento 


\section{CAPÍTULO 3: O teatro e o aprendizado.}

Este capítulo pretende discutir a importância do ensino de arte, assim como da presença da arte no ensino. A linguagem trabalhada e sobre a qual discutiremos é o teatro, entretanto, esta discussão pode ser ampliada para as demais linguagens, sem com isso retirar as especificidades de cada uma delas.

Entender o papel da arte dentro do aprendizado passa, inicialmente, pela discussão do papel da escola na formação de cada um. A educadora Terezinha Azeredo Rios propõe uma discussão sobre o que vem a ser ensino de qualidade:

O ensino da melhor qualidade é aquele que cria condições para a formação de alguém que sabe ler, escrever e contar. Ler não apenas as cartilhas, mas os sinais do mundo, a cultura do seu tempo. Escrever não apenas nos cadernos, mas no contexto de que participa, deixando seus sinais, seus símbolos. Contar não apenas números, mas sua história, espalhar sua palavra, falar de si e dos outros. Contar e cantar - nas expressões artísticas, nas manifestações religiosas, nas múltiplas e diversificadas investigações científicas. (Rios, 2001:138)

Partindo deste entendimento, quanto ao significado da qualidade no ensino, observamos a necessidade das expressões artísticas dentro da formação.

Para aprendermos a ler, escrever e contar, dentro da perspectiva apresentada por Rios, necessitamos entender a formação como um processo de construção de sentido, a construção de um sentido que só será possível na proposição de que cada aluno possa criar a sua história, possa inventar permanentemente as formas pelas quais quer estar no mundo e possa dialogar com os seus colegas para a construção de um espaço comum. O educador Cortela questiona:

Qual, então, o sentido de existirmos? O que observamos vendo tudo isso? Que não há um sentido único que nos tenha sido entregue de antemão. 
Somos antes de mais nada, construtores de sentido, porque, fundamentalmente, somos construtores de nós mesmos, a partir de uma evolução natural. (Cortela, 2001:32)

Para que possamos ser construtores de nós mesmos, precisamos acreditar que o conhecimento a ser transmitido na aprendizagem não é algo fechado e pré-definido, o que desconsideraria as relações estabelecidas no momento exato de sua construção. Se entendermos o conhecimento como algo previamente definido, não há nada além da reprodução enfadonha, que congela a capacidade de novas perspectivas para o estar no mundo, para o existir.

A pesquisadora Sanny S. da Rosa, ao discutir o papel da brincadeira no aprendizado, enfatiza:

A escola é, portanto, um lugar aberto, um espaço potencialmente transcendente. $\mathrm{Ou}$, em outras palavras, um espaço de criação. A beleza do que se passa na escola - daí sua afinidade com a arte - vem do fato de que não é um "registro da realidade", mas lugar privilegiado de trânsito entre o real e seus múltiplos sentidos entre a tradição e a criação. (Rosa, 2002:52)

A presença da arte é fundamental para que na formação possa ser vivenciado este trânsito entre o real e o imaginário, entre o real como está definido atualmente e a possibilidade de transformação desta realidade. Somente na exploração do imaginário é que conseguiremos encontrar novas soluções para a construção de uma sociedade que se aproxime dos valores de justiça, igualdade de oportunidades, garantia dos direitos básicos para todos, busca da felicidade.

Rios apresenta, com muita propriedade, o conceito de felicidadania, dentro do entendimento da felicidade como uma busca conjunta de cidadania.

É preciso deixar de lado a idéia "hollywoodiana" de felicidade, identificada com uma vida "cor-de-rosa", sem conflitos e contradições. Se afirmarmos que felicidade é outro nome para o bem comum e que o bem comum é o bem coletivo, bem público, queremos dizer que ela se identifica com a 
possibilidade de participar criativamente da sociedade, dizer sua palavra, ser ouvido e reconhecido em sua identidade, ser considerado e saber considerar no coletivo. (Rios, 2001:120)

Entendo que o ensino de arte gera esta condição de participar criativamente da sociedade. Se não experenciamos o processo de criação dentro da nossa formação, não há como compreender este conceito. A experiência é necessária para a compreensão da possibilidade de estar no mundo de forma criativa.

A busca da felicidade é fundamental para que o aprendizado seja compreendido dentro do espaço do prazer, da relação amorosa que possibilita o conhecimento, conforme salienta Cortela:

Assim, a criação e recriação do Conhecimento na escola não está apenas em falar sobre as coisas prazerosas, mas, principalmente, em falar prazerosamente sobre as coisas; ou seja, quando o educador exala gosto pelo que está ensinando, ele interessa nisso também o aluno. Não necessariamente o aluno vai apaixonar-se por aquilo, mas aprender 0 gosto é fundamental para passar a gostar. (Cortela, 2001:123)

Colocar-se na relação de ensino-aprendizagem, tendo interesse pelo que é apresentado para o grupo de alunos é condição mínima para que esta relação tenha uma base que poderá gerar espaços de criação. Sem o interesse, não ocorre envolvimento $e$, sem $\mathrm{o}$ envolvimento com $\mathrm{o}$ objeto de estudo, não existe a possibilidade de criação. Portanto, para que se estabeleça um estado criativo é necessária a condição básica de envolvimento com o que se estuda, possibilitando o aprendizado.

Outra condição para a criação ocorrer é o reconhecimento do outro, seja na relação professor-aluno, como na relação aluno-aluno. $O$ pesquisador Humberto Maturana nos apresenta um entendimento do amor como sentimento que possibilita o reconhecimento do outro: 
O amor é a emoção que constitui o domínio de ações em que nossas interações recorrentes com o outro fazem do outro um legítimo outro na convivência. As interações recorrentes no amor ampliam e estabilizam a convivência; as interações recorrentes na agressão interferem e romperem a convivência. (Maturana, 2001:22)

Será unicamente com o reconhecimento do outro como outro e, portanto, de alguém que terá necessidades e características diferentes das suas próprias, que o professor poderá estruturar sua proposta de ensino. Da mesma forma, dentro desta perspectiva é que o grupo de alunos poderá conviver e descobrir aproximações que os levem a uma construção de um bem comum.

Ora, o bem comum é algo que se constrói no esforço conjunto dos indivíduos, na superação das contradições reais dos contextos sociais concretos, na instalação da possibilidade de igualdade na diferença. É um bem coletivo, portanto, e não uma soma de experiências individuais de bem-estar, ou resultante da posse de bens materiais socialmente valorizados. (Rios, 2001:87)

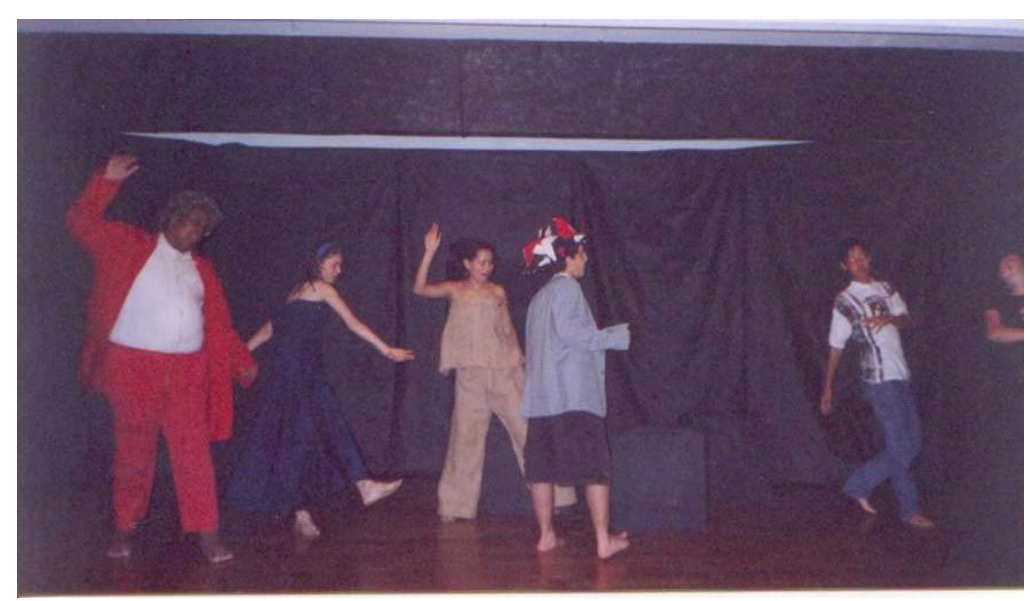

Foto 23: Aquecimento do grupo

No trabalho realizado com o grupo de teatro Pé Sujo (acima), procuramos construir alguns bens comuns. Entendo ter sido na percepção do grupo como um coletivo que apresentava necessidades e características específicas, no encaminhamento do trabalho fundamentado no amor e na relação prazerosa com 
nosso objeto de pesquisa, tendo como busca a felicidade, que estes bens puderam surgir. Ressalto, a seguir, alguns aspectos que possibilitaram esta conquista.

A estrutura que o jogo teatral apresenta solicita, em quase sua totalidade, a necessidade de ser estabelecida uma relação entre os pares para que o problema proposto possa ser solucionado. Desta forma, somente com a disponibilidade para trabalhar junto é que o jogo poderá ocorrer, resultando daí uma integração que se dá tanto pela necessidade de observação do outro como pelo prazer da conquista comum.

A impossibilidade de resolução das proposições individualmente faz que esta relação coletiva se fortaleça e crie unidade, cada um se reconhecendo como integrante de um coletivo. ${ }^{52}$

Desde o início do trabalho, foram realizadas algumas atividades pelos participantes que denotaram o cuidado de todos com o bom andamento do projeto. Uma das dificuldades que tínhamos era com respeito à limpeza da sala. Para que pudéssemos trabalhar com o chão limpo, desde o segundo encontro os alunos se dispuseram a chegar antes do horário para organização e limpeza do espaço. No primeiro dia a sala estava totalmente preparada para nosso encontro antes de minha chegada à escola. Nos demais dias nem sempre esta preparação foi anterior, porém era feita com a tranqüilidade de quem "arruma a mesa".

Em todos os encontros um dos alunos trouxe um aparelho de som e os demais foram se revezando para trazerem músicas que utilizamos no relaxamento ao final do trabalho. Não foi solicitada por mim esta colaboração, mas totalmente integrada ao trabalho de equipe.

\footnotetext{
${ }^{52}$ Entendo que no decorrer do segundo capítulo deste trabalho já ficou evidenciada a importância da estrutura do jogo para a formação do grupo.
} 
No sexto encontro com o grupo levei um lanche comunitário e um pequeno ovo de Páscoa para cada um dos alunos. A realização deste lanche comunitário fez com que todo o grupo se sentisse valorizado e cuidado. A atenção e importância demonstrada por mim, para com eles, foi extremamente apreciada pelos participantes.

Em diversos momentos do nosso projeto retomamos o lanche coletivo como forma de aproximação do grupo. Quando nos aproximamos do momento da apresentação, os alunos sugeriram que em todos os encontros fossem feitos lanches coletivos, com a contribuição de todos. Dessa forma, o intervalo passou a ser um momento de aproximação e trocas entre o grupo. Pelo fato de lancharmos juntos, passamos a compartilhar aspectos da vida pessoal de cada um, pois nem sempre tínhamos um momento para tal. O momento do lanche também possibilitava a conversa sobre acontecimentos do decorrer dos ensaios, que não tinham sido compartilhados na avaliação.

No domingo, último dia das apresentações, decidimos que comemoraríamos a realização do trabalho comendo uma pizza, na minha casa e, em todos os encontros posteriores, para avaliação do projeto, foram levados alimentos para que o lanche coletivo pudesse se realizar.

A realização do lanche coletivo passou a simbolizar a possibilidade de trocas e do compartilhar cotidiano. As questões, dúvidas e conflitos, assim como as brincadeiras ocorridas no lanche, construíram uma relação entre todos nós, que permitiu um maior envolvimento e aprofundamento no trabalho conjunto.

\section{PROTOCOLO}

A avaliação foi fundamental para a realização deste projeto. $O$ instrumento de avaliação foi o protocolo. Proposto por Koudela (1996) como forma de registro questionador e propulsor, o protocolo foi incorporado ao trabalho junto ao grupo de teatro Pé Sujo desde o segundo encontro. 
Os protocolos, realizados individualmente após cada encontro, possibilitam outra forma de avaliar o trabalho, como explica Koudela:

A síntese da aprendizagem, materializada pelo protocolo, tem sem dúvida a importante função de aquecer o grupo, promovendo o encontro. $O$ protocolo possibilita maior delimitação do foco de investigação em cada momento da aprendizagem. Eficiente instrumento na gestão intragrupais, o protocolo revelou-se um instrumento radicalmente democrático, ao permitir a articulação de um método que busca a prática da teoria e a teoria da prática. (Koudela, 2001: 91/92)

Dentro de uma visão de que a avaliação é um momento de retomada do que foi realizado e um questionamento das possibilidades que se seguirão a partir de então, é que este sistema foi escolhido.

$\mathrm{Na}$ proposta de jogos teatrais, a avaliação participa intensamente do entendimento e da experimentação do jogo. Para que o jogador possa identificar qual o foco de cada um dos jogos e se ele se ateve ao mesmo, é fundamental o momento de avaliação. Spolin esclarece:

A avaliação verdadeira, que está baseada no problema (FOCO) a ser solucionado, elimina críticas e julgamento de valores e dissolve a necessidade do o professor/jogador e/ou o jogador/aluno dominar, controlar, fazer preleições e/ou ensinamentos. Essa interação e discussão objetiva entre jogadores e grupos de jogadores desenvolvem confiança mútua. Forma-se um grupo de parceiros e todos estão livres para assumir responsabilidade pela sua parte do todo, jogando.(Spolin, 2001:33)

No jogo teatral, a avaliação ocorre com a participação de todos os envolvidos: jogador, platéia e coordenador. A clareza de quais são os objetivos de cada jogo, possibilita que não se vivencie a avaliação como um momento punitivo, mas sim como a reflexão necessária para a tomada de consciência e para a apropriação da experiência obtida com o ato de jogar. 
Observamos, no depoimento de Spolin, a importância do foco para que a avaliação não se transforme em uma busca por parte dos alunos/jogadores em satisfazer as expectativas do coordenador/professor. O problema a ser solucionado, proposto pelo foco é o que irá gerar parceria entre os jogadores, possibilitando que o jogo desenvolva-se com liberdade.

Outro elemento que compõe o jogo teatral e que se relaciona diretamente com a avaliação, é a Instrução. A maneira com que o professor/coordenador mantém o foco presente, através das instruções dadas ao jogador, faz com que ele trabalhe como parceiro e não como um elemento distante, que contém o poder de julgar o ocorrido.

A instrução deve conduzir o processo teatral, libertando pensamentos e emoções ocultas, sem interromper diálogo e ação. A instrução permite que o professor tenha a oportunidade de participar do jogo. Jogos teatrais não são lições! Ninguém sabe o que vai acontecer! (Spolin, 2001:33)

Podemos observar o entendimento dado à avaliação pelo grupo de alunos, nas respostas à pergunta Como você vê a avaliação?

Vejo como uma forma de melhorar, sempre. Mariana

Vejo como uma maneira de melhorar cada jogo ou cena. Edmilson

Ótima, para sabermos do que e onde queremos chegar. Priscila

Nos ajuda a ver nós mesmos com outros olhos. Daniel

Eu vejo a avaliação como uma forma de se conversar e de se resolver as cenas e os jogos, no curso isso se tornou uma coisa habitual, muito bom! Solange

As avaliações foram muito boas pelo menos para mim, pois assim eu pude melhorar nos outros jogos o que não fiz bem no outro. Giovani 
Para a realização dos protocolos, junto ao grupo de teatro Pé Sujo, definimos qual seria o responsável pelo protocolo de acordo com a disponibilidade que cada aluno apresentava. Não foi em todos os encontros que os alunos trouxeram o protocolo, mas mesmo quando ele não foi trazido, iniciávamos o trabalho retomando as atividades do encontro anterior.

As respostas dadas à pergunta Qual a função dos protocolos no nosso projeto? denota a compreensão do significado do protocolo para o trabalho e também a dificuldade apresentada pelo registro escrito e pela reflexão sobre o que foi feito:

Como um diário, registrou tudo o que fazemos... mas é meio chatinho fazelo, precisa pensar muito. Mariana

Sua função foi nos vigiar de certa maneira para que nós mantivéssemos uma boa freqüência de encontros e para que refletíssemos sobre cada dia, cada jogo e cada momento e sensação. Edmilson

O protocolo é a base de tudo, é uma segurança, saber que os outros estão interessados e a opinião de todos, o que achou e o que não achou. Gostava de fazer os protocolos, porque todos tinham que saber o que tinha acontecido, o que eu achei e tudo o mais. Priscila

Relembrar o que foi feito e registrar o que foi feito. Daniel

A função do protocolo foi saber de forma individual o que cada um de nós aprende com os jogos pra mim ele foi muito importante. Solange

A função do protocolo, era de fazer-nos pensar no que aquele jogo nos ajudou a entender, ou melhor nos ensinou, e no que ele ajudou muito.

\section{Giovani}

Todo início de aula fizemos uma roda para a leitura do protocolo, discutindo os conceitos apresentados, com esclarecimento de minha parte sobre qual seria o trabalho daquele dia. Nesse momento também resolvíamos problemas de relacionamento do grupo, quando necessário. 
O estabelecimento de uma roda de conversa no início do trabalho fez com que ficasse clara a possibilidade de que cada um dos participantes trouxesse sugestões ou reclamações para o grupo.

Em nenhum momento existiu dúvida sobre meu papel de coordenadora. O entendimento do que é a coordenação de um trabalho foi estabelecido dentro deste prisma, que ensinar ou coordenar não significa retirar a possibilidade de diálogo e de posicionamento por parte dos alunos.

A compreensão do papel do coordenador, por parte dos participantes, pode ser entendida pelas respostas dadas à pergunta Como você vê o papel da Lelê ${ }^{53}$, coordenadora do trabalho?

No começo você pediu para não te chamarmos de professora ${ }^{54}$, mas até hoje eu ainda a vejo assim, pois você me ensinou muita coisa como uma professora amiga, coordenadora e compreensiva. Mariana

Eu vejo como uma amiga, mãe, as vezes dura, as vezes cansada mas uma ótima profissional no trabalho que ela exerce, além disso ela tem uma ótima visão do que é realmente teatro e que futuramente poderá render frutos para os outros e principalmente para ela. Edmilson

Uma super diretora, super amiga, super mãe, super professora. Ela ajudava em todos os momentos, ficava brava nas horas certas e feliz em quase todas as horas. Super legal e engraçada. Priscila

Uma amiga-coordenadora que nos ajuda em nossas dificuldades, seu papel é muito assustador e exigente, isso como coordenadora, mas como Lelê, muito amiga e compreensiva. Daniel

Eu já havia feito oficina de teatro e esse curso trouxe uma coordenadora muito aberta a pessoas de personalidades diferentes e com uma experiência incrível! Posso dizer que aprendemos muito. Solange

O papel da Lêlê, foi muito bom, pois ela nos orientava quando estávamos meio perdidos em cena, e se não me falha a memória isso que ela fez se chama direção! Além de produção, roteiro... Giovani

\footnotetext{
${ }^{53} \mathrm{O}$ meu apelido e nome artístico é Lelê.

${ }^{54} \mathrm{O}$ meu pedido foi de que não me chamassem unicamente de professora, mas também por Lelê.
} 
As respostas dadas pelo grupo de alunos denota o bom relacionamento estabelecido entre nós. Entendo que as condições do trabalho favoreceram esta situação. O fato dos alunos optarem por participar do projeto, sem nenhuma obrigatoriedade, criou uma disponibilidade bastante diferente da encontrada, de maneira geral, nas salas de aula curriculares. Meu interesse pelo projeto, assim como a dedicação à preparação de cada encontro, também trouxe uma possibilidade de abertura e compreensão para com o grupo, que nem sempre é possível por parte dos professores.

Entretanto, apesar da tônica de nosso relacionamento ter sido o respeito mútuo e a compreensão das necessidades de todos nós, nem todos os momentos foram pacíficos ou tranqüilos.

No segundo capítulo deste trabalho, expus uma situação na qual um dos alunos não conseguia realizar uma das cenas pois esquecia a fala, reiteradamente. O meu posicionamento foi de, após diversas tentativas de estimulá-lo a resolver a dificuldade apresentada, ameaçá-lo com a possibilidade de perder a cena.

Esta situação denota a fragilidade desta pesquisadora, e provavelmente de boa parte dos professores, em manter-se fiel à uma postura realmente democrática no aprendizado. Ao não saber como resolver a situação, meu posicionamento foi absolutamente autoritário, deixando claro para o grupo que, embora as decisões fossem coletivas, estava mantido o meu direito ao poder de decisão acima das vontades alheias, como muitas vezes é feito nas escolas, pelos professores.

Minha surpresa perante esta atitude deveu-se, tanto à minha atitude autoritária, como à tranqüilidade com que o grupo a aceituo. Evidentemente, os alunos estão acostumados com esta forma de agir por parte dos professores e a aceitaram sem nenhum questionamento. Prefiro acreditar que além deste costume, a aceitação da minha atitude autoritária deveu-se também à confiança já estabelecida entre todos nós. 
Ressaltei aqui esta situação, pois entendo que apesar de minha crença e prática democrática, não são todos os momentos em que conseguimos nos manter nesta postura; e que o aprendizado gera conflitos e contradições em todos os seus participantes.

\section{O CORPO}

A realização do trabalho teatral se dá fundamentalmente com o corpo. Os recursos utilizados para a montagem de uma peça, seja em seu espaço, com elementos cenográficos, seja no figurino, sonoplastia e iluminação, podem aportar diferentes soluções e efeitos para a apresentação, porém é no trabalho corporal que se dá a transformação e a criação da linguagem teatral.

No ensino de teatro, onde a preocupação central está no aprendizado que se estabelece com o contato com essa linguagem, a importância do trabalho corporal torna-se ainda maior.

A linguagem teatral, assim como a dança, possibilitam um conhecimento do próprio corpo e uma ampliação das possibilidades de vivência dele e com ele. Ao descobrir maneiras pelas quais podemos nos expressar corporalmente, descobrimos novas formas de nos movimentarmos, novas expressões e recursos que podemos utilizar na relação com outros corpos, nas relações sociais.

O conhecimento do corpo, estabelecido pelo jogo teatral, cria uma amplitude de gestos que dão ao aluno outra percepção de si e da sociedade. $O$ ato de jogar gera diferentes resoluções para momentos propostos pelo jogo, que são facilmente associados a momentos da vida cotidiana de cada um dos participantes.

A percepção da gestualidade, criada como solução para diferentes situações e emoções que o jogo apresenta, leva ao aluno a amplitude de entendimento da leitura 
corporal e gestual feita de forma, muitas vezes, inconsciente. Koudela reflete sobre o jogo e o corpo para os adolescentes:

O objeto de observação mais próximo para avaliar a estrutura do gesto era o reconhecimento do próprio corpo. Através do jogo de improvisação, trabalhamos com a resistência característica dessa faixa etária em utilizar o próprio corpo e ocupar o espaço físico. (Koudela, 1990: 78)

Ao avaliarmos os jogos e as soluções encontradas, ao explorarmos soluções para as cenas, damos ao aluno um maior domínio e capacidade de "ler" o mundo que o rodeia, de atribuir significado e compreender o repertório gestual presente no seu cotidiano.

Além da importância no aprendizado sobre o próprio corpo e sobre os corpos que convivemos, o ensino de teatro traz para o aprendizado a reflexão sobre a corporalidade.

O conceito de fisicalização proposto por Spolin, esclarece a importância da corporalidade no aprendizado.

A realidade só pode ser física. Nesse meio físico ela é concebida e comunicada através do equipamento sensorial. A vida nasce de relacionamentos físicos. A faísca de fogo numa pedra, o barulho das ondas ao quebrarem na praia. A criança gerada pelo homem e pela mulher. O físico é o conhecido, e através dele encontramos o caminho para o desconhecido, o intuitivo. (...) $O$ ator cria a realidade teatral tornando-a física. (Spolin, 1987:14/15)

A possibilidade de entrar em contato com o físico, tornando real o imaginário dá-se pelo conhecimento e exploração do corpo. Trabalhar com a fisicalização é uma forma de deixar claro o significado do corpo para o aprendizado.

O aprendizado pressupõe transformações corporais. Não é apenas no teatro e na dança que o corpo está presente, ainda que muitas vezes ele seja completamente 
ignorado. Trazer o teatro para o aprendizado é também uma forma de garantir a presença corporal na construção de conhecimento.

Observamos, nas respostas dadas pelos alunos à pergunta A percepção sobre o teu corpo mudou com o trabalho? a importância desta valorização dentro da Escola:

Sim, vi que quando sou um personagem tem que ter os movimentos do corpo pois ele diz o que sentimos talvez muito mais do que a fala. Mariana

Eu melhorei muito, meu corpo fez coisas que eu pensei que não poderia fazer. A respiração melhorou e meu corpo se acostumou com exercícios e senti que há lugares no corpo com enorme sensibilidade. Edmilson

Conheci muito mais o meu corpo, senti sensações que nunca antes sentia. Concentrações deliciosas, muito boa. Mexer o corpo com mais facilidade. Priscila

Apenas um melhoramento da visão do meu corpo em relação a percepção de representação. Daniel

O teatro traz com certeza outra percepção do nosso corpo e da sua importância não só para o teatro, a partir disso partiremos com mais consciência sobre tudo além do nosso corpo. Solange

O que mudou no meu relacionamento com o corpo foi a respiração e alcance dos braços, até onde eles vão, que adquiri no jogo/exercício de ocupar o espaço. Giovani

Nestes depoimentos observamos as várias transformações corporais que o trabalho teatral gerou em cada um dos participantes. Evidencia-se não apenas a compreensão das possibilidades de expressão descobertas nesta experiência, como a ampliação da capacidade de sentir e perceber o próprio corpo.

\section{APRESENTAÇÕES}

Desde o início do projeto já existia a perspectiva de apresentarmos uma peça de teatro. A escolha por tornar público o trabalho desenvolvido com o grupo no decorrer do ano deve-se fundamentalmente às características da linguagem teatral. 
$\mathrm{Na}$ estrutura dos jogos teatrais, propostos por Spolin, a presença da platéia é parte integrante do trabalho. O jogo teatral pressupõe a existência da platéia e esta possibilita uma maior percepção e compreensão do próprio jogo. O fazer teatral, quando inclui a platéia no decorrer de todo o processo e não somente na finalização, desenvolve a capacidade de observação e reflexão sobre o seu próprio fazer.

Durante todo o projeto tivemos o grupo como platéia de si mesmo, observando e refletindo sobre cada um dos jogos realizados e, posteriormente, sobre a montagem das cenas que deram unidade à peça apresentada.

No período de finalização do trabalho convidamos alguns amigos para assistirem dois ensaios corridos, podendo desta forma debater sobre a montagem feita até aquele momento. A possibilidade de conversarmos sobre a peça, com esta pequena platéia composta de pessoas que não haviam participado do trabalho, tranqüilizou o grupo de alunos, pois ainda permanecia alguma dúvida sobre a possibilidade de compreensão da narrativa, o que acabou com os comentários dos amigos.

A escolha de um cenário não realista causava incertezas sobre a possibilidade de compreensão da transformação do espaço, e de que a platéia não pudesse entender as configurações estabelecidas pelo uso dos cubos.

Preparamos as apresentações de forma que elas ocorreram no final de semana que coincidiu com a semana cultural organizada pela escola. As apresentações ocorreram na sexta-feira, sábado e domingo à noite. Foram distribuídos cartazes e convites para os alunos da escola, familiares e amigos dos participantes do projeto.

O momento da apresentação gera a expectativa do compartilhar, podemos entender seu significado, segundo Spolin:

A apresentação leva à fruição de todo o processo criativo de fazer uma peça e a platéia deve ser envolvida neste processo. A platéia é o último raio que completa a roda, e sua relação não apenas com a peça mas 
também com a atuação é da maior importância. A resposta da platéia pode ajuda-lo a avaliar sua produção.

Ninguém deve usar uma platéia para a autoglorificação ou por razões exibicionistas. Se isto ocorrer, tudo aquilo por que você e seus atores trabalharam será destruído. Por outro lado, se o conceito de compartilhar com a platéia estiver compreendido, os atores farão apresentações excitantes. (Spolin, 1999:109)

No decorrer de todos os encontros, experimentamos o sentimento de alegria pela criação e pelas descobertas realizadas conjuntamente. A expectativa de tornar público, assim como o medo do julgamento por parte das pessoas que não haviam participado desta criação, foi muito grande no primeiro dia de apresentação.

No dia 26 de outubro de 2001, dia da primeira apresentação, nos encontramos na escola no início da tarde. Eu levei a iluminação a ser montada, e passamos muitas horas instalando os equipamentos. Metade do grupo ocupou-se com as luzes, enquanto a outra metade preparou os cartazes com as fotos para serem expostas no saguão da escola. Limpamos toda a sala e organizamos o espaço para a apresentação.

Terminamos os preparativos às 5 da tarde e resolvemos não fazer nenhum ensaio, pois a apresentação começaria às 19 horas. Paramos para um descanso no qual ficamos todos "empoleirados" em volta da mesa de luz e som, local onde eu permaneci durante as apresentações. Neste momento prévio à apresentação foi evidente a necessidade de proximidade física de todo o grupo, necessidade de contato corporal, que dava a todos segurança para a realização do trabalho.

Todos estavam muito cansados e tensos. Fizemos um relaxamento antes de começarmos a nos arrumar para a apresentação. (Figura 24, abaixo) No momento de fazer o aquecimento e a concentração, falei ao grupo da importância daquele momento e de que deveríamos trazer para a cena toda a bagagem dos encontros. A Sidnéia estava especialmente nervosa, não conseguindo ficar parada na concentração. No final da minha fala ela sugeriu que rezássemos um Pai Nosso para que tudo corresse bem, o que foi aceito por todos, mesmo pelo Daniel que não tem a 
mesma religião. A Mariana puxou a oração, depois da qual demos início à entrada da platéia.

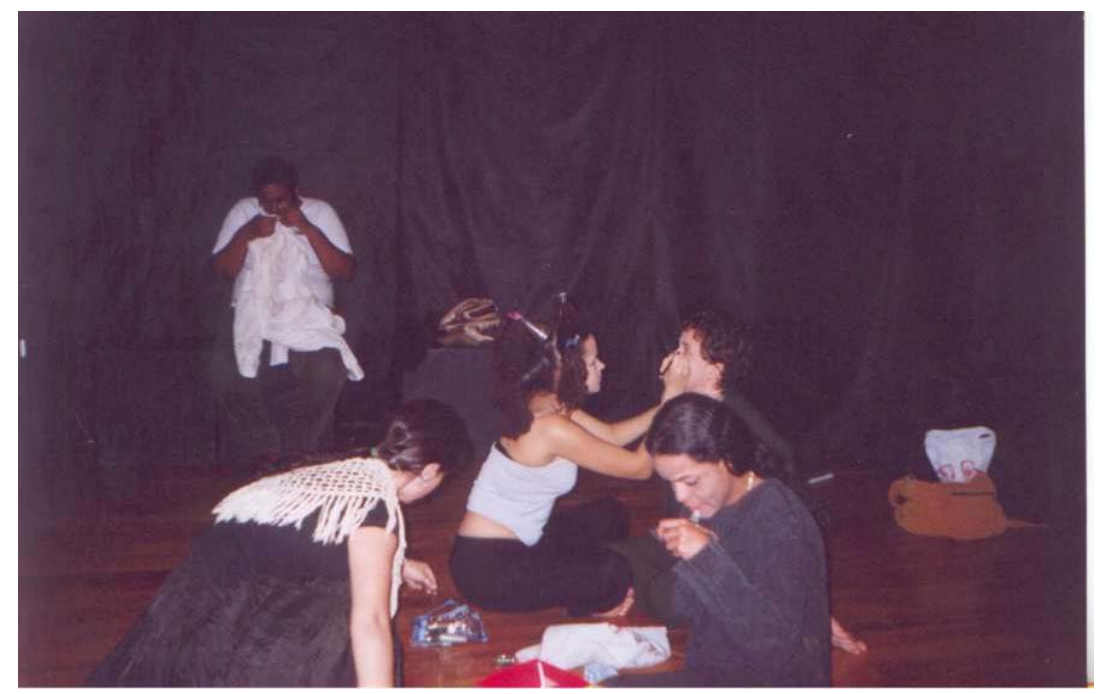

Figura 24: Maquiagem

O teatro estava lotado, vieram muitos alunos e professores. Foi uma surpresa a quantidade de alunos que assistiu à peça, pois até este momento, o projeto ocorreu dentro da escola, mas não teve nenhuma participação de professores ou colegas.

Não aconteceu nenhum problema com as cenas, ninguém se atrapalhou ou teve que interromper a apresentação por não saber como agir. Na cena da ponte de cristal, as meninas incluíram alguns cacos pois, no momento de colocar a roupa das virgens, o penteado da Solange, inventado no dia da apresentação, causou surpresas, já que ela colocou cones na cabeça que quase impossibilitaram a passagem da gola. ${ }^{55}$

No final, o grupo foi muito aplaudido. Todos foram elogiados por colegas e professores. Boa parte dos pais estavam e gostaram muito. A recepção desta primeira apresentação gerou um clima de muita confiança e alegria no grupo.

\footnotetext{
${ }^{55}$ A personagem da narradora usava um figurino feito de tecido de chita e um penteado com o cabelo enrolado em cones. Na cena da ponte de cristal, ela permanece no palco e troca de personagem, vestindo uma túnica por cima da roupa para fazer o personagem das virgens que jogam flores na princesa. Esta túnica tinha um decote amplo, porém os cones dificultaram a passagem da cabeça, o que gerou a necessidade de improvisação.
} 
No segundo dia de apresentação, nos encontramos no meio da tarde para comentarmos a apresentação anterior e arrumarmos novamente o espaço. Fizemos um lanche coletivo e conversamos por bastante tempo sobre as impressões de cada um. Os que haviam feito o protocolo leram as impressões que tiveram. A empolgação com a receptividade da apresentação e com os elogios da platéia foi muito grande.

A segurança gerada pela primeira apresentação provocou um estado de relaxamento e de crença de um domínio sobre a situação que trouxe vários problemas para o segundo dia. Contávamos com uma platéia muito menor que a de sexta-feira, o que foi desistimulante.

Em uma das cenas, um dos alunos esqueceu completamente a fala e não conseguiu improvisar, perdendo o personagem e deixando clara a perda. Esta dificuldade em improvisar foi muito frustrante para o aluno, já que em todo o trabalho, a improvisação foi recorrente. A incapacidade de encontrar uma solução para a cena, demonstrou o quanto o momento de exposição pode ser imobilizador, se vivido como cobrança.

$\mathrm{Na}$ última cena, um dos alunos improvisou soluções que fizeram com que a cena se descaracterizasse completamente, pois ele teve, como rei, atitudes muito engraçadas e "roubou" a cena. A platéia deu muita risada, pois ficou realmente engraçado. Acredito que ele percebeu, na primeira apresentação, seu potencial para comédia e resolveu fazer uso dele. O grupo ficou muito bravo com ele e saíram todos insatisfeitos com a apresentação.

No terceiro dia de apresentação nos encontramos novamente no meio da tarde, para conversar e fazer um ensaio corrido, que seria filmado. Não pudemos fazer a filmagem, pois a Mariana não pode vir, porque estava com muita febre e ficou em casa para se recuperar para o momento da apresentação. 
Na conversa sobre a apresentação de sábado, todos foram muito duros com o aluno que havia alterado a cena, ele se desculpou com todos e tentou explicar, argumentando que achou que não entrou bem em cena e tentou fazer alguma coisa para melhorar.

Ficou claro, neste momento, o fascínio que o possível sucesso exerceu sobre o aluno. A percepção de que agindo de forma cômica ele poderia chamar a atenção sobre si, fez com que ele rompesse com o acordo grupal e se preocupasse unicamente com desenvolver a posição de destaque alcançada momentaneamente.

A reação do grupo a esta atitude foi muito rigorosa. Evidentemente, todos se sentiram traídos por terem a cena desestruturada pela vaidade de um dos integrantes. Como coordenadora do trabalho, tive apenas que intermediar o diálogo para que pudesse se manter a cumplicidade e a confiança entre o grupo.

Spolin esclarece sobre o significado do acordo de grupo:

Acordo de grupo não é conformismo com a tirania da maioria nem é a obediência cega a um líder. Pelo acordo de grupo os jogadores tem liberdade de escolha, que permite alternativas. Diferenças e similaridades são respeitadas. Ninguém é ridicularizado ao dar uma sugestão. Ninguém assume a decisão. Deferência de um pelo outro é exercitada entre os jogadores. Todos têm o direito de participar na medida de sua capacidade. Todos recebem e assumem livremente responsabilidade por sua parte no todo. Todos trabalham individualmente ao máximo para a realização do evento. (Spolin, 2001:41)

A ruptura do acordo, evidenciada pela mudança do foco da cena, sem que isto fosse uma decisão do grupo, resultou em uma situação de quebra da cumplicidade. Foi necessário que o grupo debatesse e se posicionasse com relação à atitude do colega, para que pudéssemos estabelecer novamente um espaço de confiança e de construção conjunta. Evidentemente, não foi possível para o aluno, naquele momento, assumir a atitude vaidosa, porém ele se desculpou junto ao grupo e pode, desta forma, recuperar a confiança do conjunto. 
Como seria feito um ensaio, veio uma amiga minha para assistí-lo e, para que ela pudesse saber um pouco sobre a peça, os alunos decidiram mostrar as cenas, trocando os personagens, já que a aluna que fazia a princesa não estava. Fazer estas cenas foi divertido, pois todos deram muita risada com as imitações da Mariana. Este fato nos possibilitou uma leveza no grupo, além de retomarmos as cenas, o que aqueceu o grupo para a apresentação.

A flexibilidade mostrada no decorrer das cenas, com a troca dos personagens, também evidenciou o domínio que o grupo tinha sobre a peça. A possibilidade de brincar com as cenas e de caricaturizar as atitudes dos colegas denotou a apropriação de cada um sobre a construção feita.

Podemos observar nos depoimentos dos alunos sobre as apresentações, o significado que elas tiveram:

Protocolo dos 3 dias de apresentação

Sexta $\Rightarrow$ Todo mundo nervoso! Arrumação à tarde, tira foto, põe foto, tira pano, põe pano. Chegando perto do horário todo começa a se arrumar, nos maquiamos, e eu adorei essa parte, principalmente quando eu maquiei o Geléia que ficou uma gracinha. Apresentamos, erramos um pouquinho, e correu tudo bem. Nunca tinha sentido tanta emoção de subir em um palco, perdi minha virgindade de palco. Dói, mas no fim é muito bom. Todo mundo aplaudiu, amou e eu amei, mais ainda.

Sábado $\Rightarrow$ Dia de agitação 2, eu muito calma, achava que ia correr tudo ótimo! Chegou na hora, se embaralha com as palavras, erra os movimentos, foi uma belesura! O Geléia fazendo absurdos de gracinhas na hora em que não deve, foi um caos! Mas nada é perfeito!

Domingo $\Rightarrow$ Concentração em triplo! Rezamos e pareceu que deu tudo certo! E deu mesmo! Bem no dia que precisava mais mesmo. Os alunos 
da Lelê estavam lá. ${ }^{56}$ Adorei tudo! Foi muito bem e os outros principalmente. Amei tudo. Não tenho queixas desse dia. Principalmente da imprensa nos entrevistando. Me senti uma verdadeira atriz que tinha acabado de fazer um filme.

Uma das melhores partes...

AS PIZZAS! A comilança! Adorei a casa da Lelêt ${ }^{57}$, muito linda, quando eu crescer, quero morar em uma casa igual a dela! E ter os gatos também.

E de nada do meu smile. Quero que você enfeite sua casa com ele! Priscila

26/10/01 - 1 a Apresentação - Sexta

Hoje foi a primeira apresentação... como todos eu estava na maior expectativa, começamos arrumando os últimos detalhes do palco, como a luz e etc, até de se arrumar começou o nervoso.

A partir deste momento senti: angústia, solidão, raiva, ansiedade, o próprio nervoso e sei lá, pareceu que tudo ia desabar... acho que quando estamos pra colocar em prova algo que demorou muito para ser feito e tudo que se passou teria que ser mostrado ali no palco ficamos sensíveis a qualquer atitude que nos subestime... talvez seja a insegurança.

A apresentação pra mim foi muito legal, mas muito legal mesmo... senti meu coração palpitar mais forte depois de ter passado o segundo roubo... foi tudo muito rápido, os 45 minutos da peça foram pra mim como dez. Eu adorei...

A apresentação para o público, todos pareceram gostar muito, vieram parabenizar e comentaram das cenas falando que estavam ótimas... minha mãe adorou e como estava na platéia pode ver a reação das pessoas... ela disse que todos ficaram em silêncio, ou seja, todos prestaram atenção.

\footnotetext{
${ }^{56}$ Os meus alunos do curso de pedagogia foram convidados para assistir a peça e debater com o grupo no final.

${ }^{57}$ No final das apresentações, no domingo, fomos todos para a minha casa comer pizza.
} 
Comentaram que foi muito legal a peça... enfim acho que alcançamos o objetivo.

Agradeço a Lelê que tem uma super paciência, nos coordenou todos os momentos, fez sentirmos coisas diferentes, mostrou pra mim como é ser uma artista, fazer a risada no palco e chorar na vida real, ou ao contrário... "Brigada Lelê".

É, acho que não tenho mais o que falar, apenas que pra mim está sendo super legal e muito show ver as pessoas gostarem do nosso trabalho que vem desde de lá do comecinho do ano!

Que legal...

27/10/01 2a Apresentação

A Lelê estava certa, confesso que duvidei mas a $2^{a}$ apresentação não ficou tão legal quanto a primeira. ${ }^{58} \mathrm{Em}$ algumas coisas melhoraram pois ficamos mais acostumados com o público, pudemos corrigir erros da primeira apresentação, mas talvez por não ter mais aquela empolgação de ser a primeira vez e etc, saia com menos brilho. Mas tudo bem, não ficou tão feia... amanhã fica mais legal...

Beijos

28/11/01 $3^{a}$ Apresentação

Essa apresentação foi muito legal, embora estivesse com febre acho que o pessoal e eu estávamos menos nervosos e mais confiantes... Eu percebi como cada pessoa tem uma reação diferente em algumas cenas, pois nessa última uma mulher deu risada na hora do nicho que a princesa é desprezada. Depois na hora do debate eu perguntei porque a risada e ela me deu um outro ponto de vista. O debate foi legal, teve uma certa polêmica sobre o que a princesa deu o que não deu para o príncipe, perguntaram sobre o processo de montagem e depois fomos para a casa da Lelê e comemos uma pizza muito boa, conversamos sobre a apresentação e eu fiquei muito triste em pensar que ta acabando...

\footnotetext{
${ }^{58}$ Antes da apresentação eu alertei o grupo de que tivessem muito cuidado para que a tranqüilidade conquistada pela primeira apresentação, não gerasse desatenção, coisa bastante freqüente no teatro.
} 
Foi isso que aconteceu domingo. Tchau...

\section{Mariana Bastos}

\section{Protocolo dia 26/10 Sexta-Feira}

Hoje foi a nossa estréia, todos nós estávamos muito ansiosos e nervosos mais tudo correu muito bem. Estar no palco e resumir tudo o que aprendemos desde o inicio do ano neste curso foi muito bom. A resposta do público foi ótima, todos acreditaram na sinceridade do curso ao ver o resultado no palco. Nos bastidores o clima é de muita amizade e companheirismo o que fortalece o grupo ainda mais!

Está sendo ótimo! Toda essa experiência ficará em nossas vidas para sempre.

Obrigada Lelê por ter nos dado essa oportunidade!

$\mathrm{OBS} \Rightarrow$ Uma pessoa hoje depois do espetáculo veio agradecer por termos ressucitado este grande evento que é o teatro no Alves Cruz e ao ter visto a sala cheia de gente, esta pessoa notou que a escola que quase foi fechada no ano de 2000, ressuscitou! Obrigada por isso também Lelê!

Protocolo 27/10 sábado

A apresentação de hoje foi mais calma, acabou a euforia da estréia. Começamos com um lanche, seguimos com a maquiagem e depois o relaxamento, isto é, antes veio o aquecimento do corpo, voz, etc... Como o clima estava ótimo todos fizemos o espetáculo calmos e até brincamos com os textos. Foi muito legal isto é, só o Jeléia que fez algo numa cena que chamou a atenção do público atrapalhando o andamento da cena e impedindo o público de ver o desfecho que toda a trama, fora isto, correu bem.

O público muito bom prestou atenção em tudo! Em fim foi muito legal! Último relatório do Teatro

Bem, é duro falar pela última vez, finalmente chegou o grande dia, nós iríamos apresentar o espetáculo, todos nós inclusive eu estávamos bem ansiosos pela estréia, estava tudo pronto mas mesmo assim estávamos 
com medo de dar alguma coisa errada, mas foi tudo maravilhoso, particularmente fui muito elogiada mas nem liguei pois em um grupo todos fomos bem, e todos merecem elogios, por isso os elogios a minha pessoa é válido para meus colegas de palco.

Enfim foi um momento maravilhoso e inesquecível.

\section{Solange}

\section{Protocolo da Apresentação}

Dia 27/10/2001 (sábado)

Bom, nesse dia rolou um festival de música e nos atrapalhou um pouco.

Um pouco antes do espetáculo nós fizemos um relaxamento bem divertido, estava tocando blues lá fora e para nós relaxarmos mesmo, nós dançamos.

Começou a peça e tudo ia bem, até a minha entrada. Eu não entrei bem concentrado, fiquei chateado comigo mesmo, daí fiz o pior, atrapalhei o andamento da peça, eu inventei coisas que no momento não era legal. Até hoje peço desculpas para o pessoal mas acabou tudo bem.

Dia 28/10/2001 (domingo)

Chegou o último dia de apresentação do grupo Pé Sujo no Alves Cruz. Foi legal todas essas apresentações. Chegamos depois das $15 \mathrm{~h}$ e estávamos arrumando o cenário e ajustando luzes e palco. Fizemos o relaxamento como é de costume a Sidnéia estava muito nervosa, aliás todos nós pois a vó da Lelê estaria na platéia e para nós é uma honra ter a pessoa que criou o conto que se transformou neste espetáculo. Tudo foi maravilhoso, melhor de todas apresentações, logo depois participamos de um debate com o público, em especial os alunos da Lelê e meu melhor amigo Ziun Masuda.

Enfim, já tava me esquecendo tinha um tiozinho que fez uma pergunta só para polemizar ou criar uma discussão.

Banana para ele galera! Fim

\section{Edmilson Soares de Oliveira}


$1^{\circ} \mathrm{Dia}$

Foi um dia bem agitado, trabalhamos bastante, arrumamos as luzes, limpamos tudo, ficamos muito cansados. Logo depois começamos a fazer alguns exercícios para descansar. Quando faltava pouco tempo para a apresentação nos maquiamos e alguns outros exercícios. Fiquei muito nervosa, estava até suando além do normal, todo mundo falava para eu ficar calma, eu só fiquei calma depois que entrei no palco, ocorreu tudo bem, melhor de que o inesperado.

Todo mundo adorou, os professores ficaram admirados de como todos nós representamos. O esforço valeu a pena, se pudesse recomeçar, eu faria tudo de novo. Valeu Lelê, adorei tudinho!!!!

$2^{\circ} \mathrm{Dia}$

Estava mais calma, ficamos mais confiantes em todo o momento. Quando ouvi a voz da minha mãe deu um frio na barriga mas logo passou. De manhã eu acabei brigando com uma menina que falou que não viria, que devia ser uma coisa boba, descoti tanto que acabei ficando com dor de cabeça, nem me importei porque sei que é pura inveja.

o mais importante é que saiu tudo bem, tirando algumas coisas que todo mundo sabe.

Valeu pessoal.

\section{Sidnéia}

\section{Protocolo}

Ontem foi o grande dia, a estréia, estávamos muito ansiosos, pensei que fosse ficar muito mais ansioso do que estava, ainda bem que não fiquei. Nas cenas em que fazia o pássaro, não tive muito problema, mas na hora em que ele virou príncipe, o bicho pegou, principalmente na cena em que a princesa descobre a verdade teve uma hora em que esqueci a fala, gaguejei e embacei um pouco, mas ainda bem que foi só no começo.

Nas outras cenas, pelo menos no meu consenso, fluiu, ficou legal as tiradas da Solange e da Priscila, só não gostei muito da mudança do 
Geléia, ele começou a falar com um tom mais irônico do que sério, e isso deu uma quebra do que tínhamos ensaiado, pois até quarta-feira, o rei se portava de uma maneira e ontem ele se portou de outra.

Acho que foi bom não termos ensaiado antes, só que não sei se tivéssemos ensaiado antes o Geléia ia fazer o mesmo que fez em cena ou ia continuar com o mesmo rei, iria me sentir mais perdido ainda, mas se ele mudasse no ensaio antes, talvez não me sentisse tão perdido. Foi isso.

Foi muito legal, adorei, só que a peça durou 40 minutos.

Obs: Geléia não estou te criticando, é que ensaiamos uma coisa e saiu outra, e aliás ficou legal esse rei, vamos dizer mais "caricato".

Protocolo

Ontem foi o segundo dia de apresentação, como a Lelê falou foi o dia em que tudo dá errado. Esqueci a fala, além de trocar as frases na $1^{a}$ cena em que estou com o rei. Fora isso, o Geléia não se agüentou e estragou a parte em que tinha que haver mais concentração, não tanto por parte dele, mas principalmente do Daniel, da Priscila, Mariana e da Solange que encontraram dificuldade para se concentrar e isso é a cena mais tensa da peça. Com as gracinhas dele, fez a platéia dar risada, mas não sei se eles perderam a concentração, mas atrapalha. Foi péssimo!

OBS: Geléia que quer fazer as pessoas rirem vá ao circo e seja um palhaço. Na boa, isso é pessoal. Fim

\section{Protocolo}

Domingo a apresentação foi muito legal, que pena que foi o último, mas foi muito legal, espero que possamos ver a fita que a Lelê gravou.

Depois da apresentação fomos para a casa da Lelê comer pizza porque a Mariana tava meio mal. Bem legal a casa da Lelê, e os gatinhos dela, já falei pra ela que ela é quem vai decorar minha casa (quando tiver uma é claro! E não é brincadeira) Foi dez, pena que foi o último dia. Ah, e foi bem legal o bate papo com os alunos da Lelê. Fim

\section{Giovani}


Dia 26 - Sexta - O grande dia

Um ótimo dia para mim, tive muita felicidade. No começo tive um frio de $-273^{\circ}$ graus na barriga, mas depois de uma explosão tensional nos nervos consegui fazer o combinado. Gostaria de parabenizar todos, pois a peça recebeu muitos elogios e ao meu ver, não ocorreu nenhum erro.

Gostaria de enfatizar também que tive uma ótima visão dos jogos, que me ajudaram muito para me relacionar com todos e para improvisos repentinos. Tudo ocorreu como estava programado

- O som

- $\quad$ As luzes

- O cenário

- O figurino

Para terminar, dizer que todo nosso esforço e dedicação não foi em vão. OBS: O Geléia estava muito engraçado.

Dia 27 - sábado - Segundo grande dia O dia dos erros, dia em que temos que nos concentrar para não errar, dia em que vamos relembrar o frio na barriga de ontem. Achei que foi uma quase perfeita apresentação, apesar de termos menos pessoas.

Todos fizeram corretamente o que foi combinado, exceto o Jelleya que exagerou só um pouquinho. Foi ótimo para mim pois vi mais uma vez a alegria do povão (platéia), que gostou muito. Só o que eu acho que faltou foi o último som. OBS: O Giovani foi chamado de cachorro.

Dia 28 - O terceiro grande dia!

O terceiro grande dia foi o melhor dos grandes dias. $O$ dia em que apresentamos o melhor de nós mesmos, em que tivemos um ótimo resultado em relação à todo o nosso desempenho.

A platéia era ótima, só alguns comentários foram mal colocados, eles ajudaram muito para o nosso desempenho. Todas as entradas e saídas foram perfeitas, tudo foi como o combinado.

Gostei da conversa que tivemos com as alunas da Lelê e de finais esclarecimentos. 
OBS: Curti muito a casa da Lelê

Daniel

O registro escrito feito por cada um dos alunos demonstra a emoção que as apresentações causaram, o impacto em estar com a presença do público e a importância do grupo ter construído o trabalho conjuntamente, o que fez com que todos pudessem reconhecer a segurança em estar junto.

Entendo que a expectativa gerada para com o momento da apresentação foi excessiva. Talvez a pequena relação estabelecida com os demais alunos e professores da Escola, não propiciaram um diálogo maior no decorrer de todo o projeto, criando-se um grande receio do possível julgamento.

A estrutura de $O$ jogo teatral no livro do diretor, também pode ter colaborado para a importância dada às apresentações. Sendo um livro que apresenta a utilização do jogo em uma montagem teatral, a importância dada à apresentação é grande. Mesmo não valorizando este momento, em comparação com os outros encontros, a apresentação revestiu-se de uma grande importância para o grupo de alunos.

\section{CASARAM E VIVERAM FELIZES PARA SEMPRE}

Escolhi a frase casaram e viveram felizes para sempre, tantas vezes utilizada no final dos contos de fadas, para refletir sobre o todo desta pesquisa. A idéia de felicidade plena e eterna, presente nesta frase, vem antecedida pela união dos heróis da história, resultante do casamento.

Voltando aos contos de fadas, pudemos analisar, no primeiro capítulo deste trabalho, os diversos momentos que antecedem a possibilidade de casar e viver feliz para sempre. De maneira geral, o sofrimento experimentado pelos personagens das histórias até chegarem à felicidade é grande. 
Estabelecendo um paralelo com a situação de aprendizagem, definindo que os heróis da nossa história são o corpo docente e o corpo discente, poderíamos observar que a dificuldade desta história chegar à frase final semelhante ao dos contos é considerável.

Evidentemente, não seria possível, nem desejável, uma finalização tão definitiva, pois o aprendizado não finda como os contos, é mutante e em permanente transformação. Entretanto, é necessário que se estabeleça esta idéia de casamento e de felicidade como uma busca necessária. O conceito de parceria exposto por Spolin, reforça esta idéia:

Durante as oficinas, o aluno/professor e o professor/aluno devem estar abertos para dar e receber parceria, o direito à pergunta e à resposta. Pela parceria, as habilidades individuais podem variar muito, mas todos estão dando e tomando, jogando com igualdade. Todos, alunos/professores e professores/alunos unidos enfrentam o desconhecido. (Spolin, 2001: 63)

Com a perspectiva de junção, de união, é que trago o termo do casamento, os heróis dentro da relação escolar precisam "casar" para poderem viver feliz para sempre. Sem que seja estabelecido um compromisso de se construir conjuntamente o saber, que se estabelece neste pacto prévio de união, não poderemos alcançar um ensino de qualidade.

O trabalho com os contos traz essa dimensão da superação das dificuldades para que se instaure a possibilidade do amor. Explorar o conto $O$ pássaro verde, vivenciar sua narrativa, transformá-lo em uma obra que passa a ser do grupo de alunos, possibilitou-nos a valorização do sentimento amoroso, da reflexão sobre a busca do amor como uma possibilidade de felicidade.

Estar em contato permanente com o conto do Pássaro Verde, deu a oportunidade para esse grupo de adolescentes vivenciar uma história de amor, discutir 
o significado do amor nas nossas vidas, estabelecer esta perspectiva como uma possibilidade de relação. Em um momento histórico onde se coloca uma descaracterização das histórias de amor como base das relações humanas, seja na desconfiança gerada pela violência, seja na banalização do contato corporal resultante da exploração da sexualidade como bem de consumo, trazer o amor como valor possível, parece-me necessário para a construção das relações sociais.

Neste sentido, a presença do conto dentro do universo escolar pode se tornar um valoroso aliado para a construção de uma sociedade melhor, que acredite na possibilidade de convívio entre os diferentes.

O trabalho educativo com o conto não significa a supressão das diferenças ou sua aceitação incondicional e pacífica, porém ele mostra a perspectiva do conflito que irá em direção a uma busca amorosa. Este movimento de busca, quando estabelecida a possibilidade de enxergar o outro, já pressupõe esta base amorosa.

Da mesma forma que o conto traz a história de amor como uma conquista possível, o jogo teatral está estruturado neste acordo coletivo, sem o qual nada acontece, conforme esclarece Koudela:

A relação autoritáia percebe a regra como lei. Na instituição lúdica, a regra pressupõe processo de interação. O sentido de cooperação leva ao declínio do misticismo da regra quando ela não aparece como lei exterior, mas como o resultado de uma decisão livre porque mutuamente consentida. Evidentemente, cooperação e respeito mútuo são formas de equilíbrio ideais, que só se realizam através de conflito e exercício da democracia. O consentimento mútuo, o acordo de grupo determina as possibilidades de variação da regra. (Koudela, 1990:49)

A atitude cooperativa apresentada por Koudela é a base do trabalho teatral e o ensino de teatro possibilitará que esta forma de relação seja estendida para os relacionamentos sociais, de maneira geral. 
Experimentar essa forma de acordo grupal, cria no aluno esta perspectiva para as demais relações que ele venha a estabelecer. Ter a noção do outro, como alguém que necessita do mesmo espaço que você, é fundamental para a construção de uma sociedade mais tolerante e equilibrada.

Poderíamos dizer que no conto de fadas experimentado pelo aprendizado, as estórias devem iniciar-se com o "casaram", pois é com este acordo estabelecido pelo corpo docente e o corpo discente que devemos começar nosso diálogo.Partir deste acordo é um ganho para a relação de ensino-aprendizagem. Ao ter como base uma estrutura que pressupõe o acordo coletivo, os jogos teatrais dão ao aprendizado uma importante referência.

Outro aspecto fundamental presente no ensino de teatro, assim como das demais linguagens artísticas, é a criação necessária para o contato com o objeto de estudo. Segundo Spolin:

Todas as pessoas são capazes de atuar no palco. Todas as pessoas são capazes de improvisar. As pessoas que desejarem são capazes de jogar e aprender a ter valor no palco. (...) É muito possível que o que é chamado comportamento talentoso seja uma maior capacidade individual para experenciar. Deste ponto de vista, é no aumento da capacidade individual para experenciar que a infinita potencialidade de uma personalidade pode ser evocada. (Spolin, 1987: 3)

Desenvolver a possibilidade de experenciar traz o convívio cotidiano com a criatividade. A analogia estabelecida entre a vida e a obra de arte poderá ser experimentada se mantivermos o espaço de criação no aprendizado. O ensino de arte possibilita a experimentação deste espaço, já que a obra de arte não existe sem a criação. 
Entendo que a idéia de um ensino que produza felicidade está vinculada à compreensão da educação como um espaço de busca de identidade, de construção do sujeito com a incorporação de sua subjetividade.

O experimento com o grupo de teatro Pé Sujo foi um trabalho no qual estivemos felizes para sempre. No contato e transformação do conto, na experimentação dos jogos teatrais e na construção conjunta de significados para a vida deste grupo, encontramos alguns dos sentidos do ensino de teatro.

Espero que esta pesquisa possa contribuir para um melhor entendimento e uma maior experimentação do teatro no aprendizado e na vida das pessoas. 


\section{APÊNDICE 1}

O pássaro verde 


\section{O PÁSSARO VERDE}

Era uma vez uma princesa que, quando completou 15 anos, recebeu um espelho de presente de seu pai. Era um pequeno espelho incrustado em uma caixinha muito bonita, toda enfeitada. Ela estava olhando-se no espelho, quando um pássaro verde bem grande entrou pela janela e levou o espelho.

Ela ficou impressionada com aquilo, perguntando-se por que o pássaro tinha vindo tirar o espelho dela. Seu pai, para consolá-la, deu-lhe um lindo pente de presente. Ela ficou muito feliz com o novo presente, mas quando estava penteando seus cabelos, o pássaro entrou novamente e the roubou o pente.

Ela começou a imaginar por que o pássaro estava fazendo tudo aquilo com ela. Ficou muito triste, sem entender o que acontecia, e começou a pensar todo o tempo no pássaro.

O pai, vendo o desespero da filha, procurou animá-la e the deu mais um presente, desta vez uma fita toda bordada em ouro e com pedras brilhantes. Como ela ficaria presa ao seu cabelo, não poderia ser levada pelo pássaro. No momento em que a princesa começou a amarrar a fita, ela ouviu outra vez o bater das asas: era o mesmo pássaro verde que voltava, desta vez para roubar a fita.

Ela ficou numa tristeza muito grande, perguntando por que ele fizera isso com ela. Como não encontrou resposta, começou a não comer mais, não querer mais ir a festas, não conversava com ninguém, não deu mais risada, passando os dias inteiros na cama. Seus pais ficaram muito preocupados e chamaram um médico que disse que ela não tinha nenhuma doença, só tristeza.

Os dias foram passando, e como ela não melhorou, o rei colocou um edital, dizendo que quem a fizesse rir e comer, se casaria com ela. Vieram todos os palhaços do reino, os bobos da corte, os contadores de histórias. Todos tentaram contar alguma coisa que a fizesse sorrir, mas não conseguiram.

No reino, havia um rapaz meio tonto que trabalhava na floresta. Um dia ele viu uns pedaços de lenha subirem sozinhos em uma carroça, que saiu andando sem cavalo nem cocheiro. No dia seguinte viu isso acontecer de novo e acompanhou a carroça para ver aonde ela ia. Viu que a carroça entrou em um palácio. No terceiro dia 
ele resolveu subir na carroça para ver o que havia além dos portões. Dentro do palácio, o rapaz entrou em um quarto e se escondeu debaixo da cama. Dali a pouco, um mordomo entrou com uma bacia de prata cheia de água nas mãos, colocou a bacia na janela e saiu. Depois de um momento, apareceu um pássaro verde que mergulhou na bacia e se transformou em um príncipe. O príncipe abriu um armário, pegou um espelho, deu-lhe um beijo e disse:

- Este é o espelho de minha amada - e o recolocou no lugar. Pegou então um pente, deu-lhe um beijo e disse:

- Este é o pente de minha amada - e o recolocou no lugar. Por último, pegou uma fita, deu-Ihe um beijo e disse:

- Esta é a fita de minha amada - e a recolocou no lugar.

Ao amanhecer, o príncipe se transformou novamente em pássaro e saiu voando pela janela. Ao sair do palácio o menino resolveu contar essa história para a princesa.

Ele começou a contar a história para a princesa, que não prestou atenção até que ele falou do pássaro verde. Então, ela ficou muito interessada, escutando tudo cuidadosamente. Ao terminar a história, a princesa pediu um prato de sopa, e que ele contasse tudo outra vez.

Por diversos dias quis que ele ficasse o dia inteiro repetindo a história e acabou se convencendo que o pássaro verde da história era o mesmo que lhe tinha roubado as coisas.

Quando a princesa se sentiu mais forte, combinou com o rapaz que a levasse até a floresta e em troca lhe deu uma bolsa com moedas de ouro, para que ele saísse do reino e não contasse nada a ninguém. Quando o menino a levou até a floresta ela fez o mesmo que ele havia feito. Se escondeu debaixo da cama, esperando pelo pássaro.

O pássaro verde chegou e ao banhar-se na água se transformou em um lindo príncipe, abriu o armário, pegou o espelho e disse:

- Este é o espelho de minha amada - e o recolocou no lugar. Pegou então o pente, deu-lhe um beijo e disse:

- Este é o pente de minha amada - e o recolocou no lugar. Por último, pegou a fita, deu-lhe um beijo e disse: 
- Esta é a fita de minha amada - e a recolocou no lugar.

Quando o príncipe terminou de beijar a fita, a princesa saiu de debaixo da cama e disse:

- E aqui está a sua amada.

O príncipe levou um susto muito grande e explicou que ela não deveria ter vindo pois ele tinha um encanto que o faria ser pássaro por toda a vida. Esse encanto só se romperia se alguém se sacrificasse por ele passando sete anos em um nicho a pão e água. A princesa decidiu ficar no nicho, para romper o encanto e eles poderem ficar juntos.

Durante os sete anos em que a princesa ficou no nicho, uma velha foi todos os dias levar-Ihe um pedaço de pão e um copo de água. Passados os sete anos, o príncipe voltou, abriu o nicho e a princesa, pálida, muito magra, com os cabelos todos despenteados, com as roupas velhas e sujas, caiu no chão, de tão fraca que estava. O príncipe a olhou e disse:

- Bah! A que você se reduziu pelo meu amor! Agora não te quero mais.

A princesa ficou perdida, sentindo-se abandonada, até que apareceu uma velha que Ihe deu uma bolsa cheia de moedas, na qual bastava que ela enfiasse a mão, tirando todas as moedas que precisasse, sem que elas nunca acabassem. Por encanto, a velha fez com que voltasse toda a beleza da princesa.

A princesa contratou milhões de empregados para construir um palácio enorme na frente do palácio do príncipe. O palácio da princesa era muito maior e mais bonito, deixando o príncipe muito curioso em saber quem estava construindo aquele palácio tão suntuoso. Ele enviou seus empregados até a construção para perguntar quem havia mandado construí-la, mas eles não descobriram nada.

O palácio ficou pronto em 15 dias, quando a princesa se mudou para lá. Um dia, o príncipe a viu na janela e achou-a linda, embora não a tenha reconhecido. Quando ela o viu, bateu a janela na cara dele. Ele voltou a vê-la e tentou falar com ela, mas todas as vezes ela fechava a janela. Ele foi ficando cada vez mais apaixonado, mas como ela o evitava, pediu ao pai que the dissesse que ele estava loucamente apaixonado e queria se casar com ela. 
O rei achava uma humilhação aquela moça bater a janela na cara do filho dele, o príncipe, mas, por fim, ficou com pena do filho e foi até lá pedir a mão da princesa em casamento.

O rei esperou por ela durante um longo tempo e quando já estava pronto para ir embora, ela chegou. Ele explicou que seu filho estava apaixonado por ela, querendo se casar. A princesa rejeitou o pedido de casamento, dizendo não ter intenção de casar-se.

A tristeza do príncipe fez com que seu pai voltasse lá para pedir novamente a mão da princesa em casamento. Desta vez ela aceitou o pedido, porém, com a condição de que fosse construída uma ponte de cristal entre os dois terraços dos castelos, que seria por onde ela passaria no momento de se casar.

No dia do casamento, a princesa foi caminhando até o palácio do príncipe pela ponte de cristal, no seu vestido de noiva. Enquanto ela passava, as dez virgens mais lindas do reino jogavam pétalas de rosas. De repente, no meio do caminho, a princesa parou e disse:

- Uma pétala me feriu, não me caso mais. - Deu meia volta e retornou para dentro de seu palácio.

O príncipe ficou desesperado. Passados alguns dias, pediu ao rei, seu pai, que voltasse lá e a convencesse a se casar. O rei não concordou, mas o príncipe começou a adoecer de tristeza, parou de comer, deixou de passear, não conversava com mais ninguém, e então o rei, preocupado com a saúde do filho, voltou para pedi-la em casamento novamente.

Desta vez a princesa o fez esperar ainda mais, e quando o rei a pediu em casamento, ela aceitou, com a condição de que uma semana antes divulgassem para todo o reino que o príncipe estava muito doente e que no dia do casamento se espalhasse a notícia de que ele havia morrido. Ela iria ao velório e eles se casariam.

O rei não queria aceitar, mas como o príncipe estava mesmo muito doente e ele temia que seu filho morresse realmente caso não se casasse, aceitou a absurda proposta da princesa.

No dia do casamento, os sinos de todas as igrejas tocaram a dobrado e todo o reino ficou sabendo que o príncipe havia morrido. Foi realizado o cortejo que levava o 
príncipe para a igreja e a princesa demorou muitas horas a chegar. Ao aparecer, toda vestida de preto com um grande véu cobrindo seu rosto, subiu no cadafalso. Vendo o príncipe quase morto, pálido, doente, ela levantou o véu e lhe disse:

- Bah! A que você se reduziu pelo meu amor. Agora não te quero mais. - E saiu.

Foi só neste momento que ele a reconheceu. Correu atrás dela, perguntandoIhe por que o fizera sofrer tanto e ela respondeu que ele havia feito o mesmo com ela, pois não havia sido pouco o que ela havia sofrido todos aqueles anos no nicho para depois ter sido desprezada.

Eles, então, se entenderam, explicaram tudo ao rei, que passou a compreender as razões de tudo aquilo, casaram e viveram felizes para sempre. 


\section{Apêndice 2}

Roteiro para o pássaro verde 


\section{ROTEIRO PARA O PÁSSARO VERDE}

\section{PERSONAGENS:}

Narradores

Princesa

Príncipe

Rei (pai da princesa)

Rei (pai do príncipe)

Menino tonto

Velha

Mordomo

\section{PERSONAGENS COLETIVOS:}

Bobos da corte

Povo do reino

Virgens

\section{CENA 1}

Narradores apresentam os personagens e dizem que a princesa fez 15 anos.

\section{CENA 2}

O Rei dá o espelho para a princesa. Deixar claro a tranqüilidade reinante até então e a mudança de momento de vida da princesa, ter deixado de ser criança.

\section{CENA 3}

Roubo do espelho pelo pássaro.

\section{CENA 4}

Princesa se surpreende, lamenta a perda do objeto tão importante. 


\section{CENA 5}

Princesa ganha o pente e está se penteando.

\section{CENA 6}

O pássaro rouba o pente e a princesa se entristece muito, se questiona sobre tudo aquilo, sobre a razão de todos aqueles roubos.

\section{CENA 7}

Princesa ganha a fita para o cabelo.

\section{CENA 8}

Pássaro rouba a fita no momento em que a princesa a está colocando.

\section{CENA 9}

O narrador explica que a princesa está muito doente. No meio da sua narrativa entra o arauto para informar a decisão do Rei.

\section{CENA 10}

A princesa já está doente, na cama, o rei tenta animá-la, entram os bobos da corte para tentar distraí-la. A princesa não reage a ninguém.

\section{CENA 11}

Narrador explica que ninguém, até agora, havia conseguido distrair a princesa e começa a explicar a existência do tonto, enquanto ele vai falando o tonto vai aparecendo e agindo conforme as coisas que o narrador narra. Os objetos não aparecem, mas a reação do tonto faz com que estes se tornem presentes.

\section{CENA 12}

Menino contando para a princesa o que viu. A cena mostra os dias passando e o menino contando tudo novamente. A princesa pede que ele a leve ao local onde viu a carroça em troca de uma bolsa cheia de moedas de ouro. 


\section{CENA 13}

A princesa está debaixo da cama, o pássaro entra e se transforma em príncipe, beija os objetos e ela sai de debaixo da cama e declara o seu amor, concordando em ficar no nicho por sete anos.

\section{CENA 14}

Princesa no nicho. A princesa fica parada enquanto outras mulheres vão fazendo serviços de casa de forma repetida, várias vezes, tornando visível o passar do tempo.

\section{CENA 15}

O príncipe abre a porta do nicho e a princesa cai no chão. O príncipe sai e a deixa só, ela vai rastejando e depois andando até a rua e senta no meio fio, chorando.

\section{CENA 16}

A velha se aproxima e pergunta o que ela tem, ela explica tudo o que aconteceu e a velha the dá uma bolsa cheia de dinheiro, que nunca acaba, e a deixa bonita novamente.

\section{CENA 17}

Narrador explica que a princesa construiu um palácio na frente do palácio do príncipe e para lá se mudou, fazendo com que o príncipe se apaixonasse por ela, sem reconhecê-la.

\section{CENA 18}

Príncipe olhando o palácio, procurando a princesa, entra o rei e o príncipe o convence a pedir a mão da princesa em casamento.

\section{CENA 19}

Rei volta ao palácio e explica para ao filho que a princesa não aceitou o pedido e o fez esperar por muito tempo, até recebe-lo. 


\section{CENA 20}

Príncipe tentando ver a princesa e falar com ela, entra o rei . Príncipe convence o rei a pedí-la em casamento novamente.

\section{CENA 21}

O narrador explica que a princesa aceitou, colocando como condição a construção da ponte de cristal entre os dois palácios.

\section{CENA 22}

Casamento. A princesa vai passando pela ponte e volta, por ter sido ferida por uma pétala. Príncipe fica arrasado.

\section{CENA 23}

Rei gritando com o príncipe, que anda atrás dele implorando que volte a pedir a mão da princesa. Nesta cena se vê o desânimo do príncipe e a cara de doente.

\section{CENA 24}

Rei e princesa conversando, a princesa de costas todo o tempo, só se vê o rei. A princesa aceita o casamento, colocando a condição de que seja no meio de um funeral falso do príncipe.

\section{CENA 25}

Narrador explica que o rei concordou com tudo, que a notícia da doença do príncipe se espalhou pelo reino e depois a da morte, ocorrendo então o funeral. O narrador vai explicando, enquanto todos vão entrando com o príncipe que está sendo carregado, e o colocam para ser velado. Todos ficam chorando e se lamentando ao seu lado. 


\section{CENA 26}

A princesa entra na igreja e vai até o caixão, onde despreza o príncipe com a mesma frase utilizada por ele quando abriu o nicho. O príncipe a reconhece, eles se entendem e explicam tudo ao rei.

\section{CENA 27}

Narrador explica que eles se casam e vivem felizes para sempre. 
Apêndice 3

\section{Texto dramático - O pássaro verde}




\section{O PÁSSARO VERDE}

Transcriação para teatro Lelê Ancona

PERSONAGENS:

Princesa

Príncipe

Rei (pai da princesa)

Rei (pai do príncipe)

Velha

Menino

Arauto

Narrador

PERSONAGENS COLETIVOS

Bobos da corte

Povo

Virgem

Donas de casa

\section{CENA 1}

Narrador: Era uma vez um reino que tinha uma princesa muito bonita. Ela vivia com seus pais que a amavam muito, como é costume acontecer entre pais e filhos. Chegou então o dia em que ela fez quinze anos e... Olhem lá! Lá está a princesa!

\section{CENA 2}

Princesa em seu quarto. Entra o rei.

Rei: Filha.

Princesa: Oi pai.

Rei: Tenho uma surpresa pra você.

Princesa: Oba! O que é?

Rei: É o teu presente de aniversário.

Princesa: Uau! Que legal, pai. Vou ganhar agora?

Rei: Vai, mas vai ter que adivinhar. Fecha os olhos!

Princesa: Pronto, pode me dar!

Rei: Cuidado, não deixe cair, pode quebrar.

Princesa: Posso abrir?

Rei: Abre, abre. Acho que você vai gostar, acho que é perfeito para uma moça. Eu diria que é necessário para uma mulher.

Princesa: Então vou adorar, afinal hoje posso dizer que virei mulher! 
Rei: Então?

Princesa: É quadrado, tem pecinhas e uma parte lisa! O que é? Me dá mais uma dica!

Rei: É um presente que vai te ajudar a ver com que forma você vai ser mulher.

Princesa: Um espelho! Acertei?

Rei: Abre os olhos e veja.

Princesa: Que lindo pai. Com um espelho desse eu vou ficar mais bonita, ele é lindo demais!

Rei: Tinha que ser um a altura da tua beleza.

Princesa: Obrigada.

Rei: Gostou?

Princesa: Adorei! Adorei mesmo! Dá mais vontade de se olhar, fico mais bonita aqui.

Rei: Então aproveita, fique aí se admirando que eu volto mais tarde.

Rei sai do quarto. Princesa está se olhando no espelho, entra o Pássaro Verde e leva o espelho dela.

Princesa: Ei, não! O que você tá fazendo? Volta aqui! O que é isso! Esse espelho é meu, meu presente de 15 anos!

Princesa fica no quarto, triste, indignada com o roubo. Entra o Rei.

Rei: Filha, deixa disso, um espelho não vale a tua alegria.

Princesa: Não era um espelho, era o meu espelho. O espelho que você me deu pelos meus 15 anos!

Rei: Pois agora vou te dar outro presente, assim você esquece o espelho.

Princesa: Esquecer não vou mas outro presente é bem legal!

Rei: Aqui está!

Princesa: Nossa! Pai! Que demais esse pente! É incrível, você conseguiu um presente tão legal quanto o espelho.

Rei: Sabia que você gostaria. Agora vai ter os cabelos mais bem penteados do reino.

Princesa: Vou começar agora mesmo!

Rei: Fico feliz por te ver contente novamente, não agüentava mais aquela cara de fim de mundo! Até já.

Princesa: Até!

Rei sai do quarto.

Princesa: Obrigada pai!

Princesa vai para a frente do espelho e fica se penteando. Entra o Pássaro Verde sem ser visto e leva o pente de suas mãos.

Princesa: Não, não, não! Esse também, não! Por que você ta fazendo isso? Por que você ta levando todos os meus presentes! Justo estes, que são tão especiais. Por que comigo? Não tem mais um monte de janelas neste palácio pra você entrar? Pai! Pai, o pássaro outra vez. 
Entra o Rei.

Rei: O que tá acontecendo filha? Por que você ta gritando assim?

Princesa: Ele me roubou novamente, dessa vez o pente que acabei de ganhar!

Rei: O mesmo pássaro?

Princesa: O mesmo, eu vi, eu não entendo! Por que ele tá fazendo isso comigo? O que eu fiz pra que ele levar tudo o que eu ganho.

Rei: Que chatísse esse pássaro mas agora mesmo vou buscar um presente que não vai ter pássaro nenhum que roube.

Rei sai do quarto.

Princesa: E o que importa? Eu não vou ter nem meu espelho, nem meu pente de volta! Que pássaro será esse? Por que comigo?

Rei volta com outro presente.

Rei: Aqui está! Esse não poderá ser roubado por pássaro nenhum, vai ficar preso ao teu corpo e não vai ter pássaro que o tire de você. Este presente será teu da mesma forma como são teus os 15 anos que você acabou de completar.

Princesa: Obrigada pai. É linda!

Rei: Vamos filha, tira essa expressão de tristeza da cara. Esse presente não é menos especial que o espelho ou o pente.

Princesa: É verdade. É um presentão!

Rei: Amarre nos teus cabelos e não vai ter nada nem ninguém que o leve.

Rei sai do quarto. Princesa fica por um tempo observando a fita.

Princesa: Que linda, quantos desenhos bordados! Que pedra brilhante!

Princesa solta a fita para pentear o cabelo. Pega a fita novamente e quando vai coloca-la, o Pássaro Verde entra e rouba a fita novamente.

\section{CENA 3}

A cena se passa nas ruas do reino.

Narrador: Não há nada que deixe a princesa feliz! Faz muitos dias que ela não quer saber de sair da cama, chorou muito e agora já não quer comer e nem chora mais. Fica lá, deitada, sem vontade de nada. O rei já tentou de tudo, já quis lhe dar todos os presentes possíveis, comprou novos espelhos, pentes e fitas na tentativa de alegra-la mas ela não aceita, dizendo que todos eles serão roubados! Pobre princesa! O que se conta é que ela...

Arauto: Senhoras e senhores! Povo deste reino. O nosso rei vem avisar que a princesa está muito triste, já não come há dias e adoece de fraqueza. O Rei convoca 
todos os bobos da corte, palhaços, contadores de histórias, encantadores ou qualquer pessoa do reino que acredite poder alegrar a princesa a comparecer ao palácio para tentar diverti-la. Quem conseguir fazer a princesa sorrir e voltar a comer, terá sua mão concedida em casamento. As portas do palácio estão abertas a partir deste momento!

\section{CENA 4}

A cena se passa no quarto da princesa, ela está deitada na cama. Bobos da corte tentando animar a princesa que não reage a nenhum.

\section{CENA 5}

A cena se passa na floresta. O menino vai fazendo toda a seqüência narrada.

Narrador: Ninguém conseguiu anima-la! A princesa continua deitada sem comer, sem vontade de fazer nada, sem achar graça em nenhuma das brincadeiras feitas apenas para diverti-la. Mas existe neste reino um menino, um menino meio tonto que trabalha na floresta recolhendo lenha. Um dia, ele estava por lá quando viu uma carroça parada sem ninguém por perto. Olhou melhor e viu que a lenha que estava ao lado da carroça subiu sozinha e a carroça lá se foi.

Menino: Cara, que maluquice é essa? Olha só! Mas como é que essa lenha ta subindo aí sozinha? Ei! Tem alguém aí? Não tem não!

Narrador: Ele achou aquilo muito estranho e voltou ao mesmo local no dia seguinte. Depois da lenha subir sozinha, a carroça começou a andar sem que ninguém a levasse e o menino a seguiu, vendo que ela entrou dentro de um palácio. No terceiro dia, o menino seguiu a carroça, subiu dentro dela e entrou no palácio. Quando estava dentro de um dos quartos ouviu um barulho e se escondeu debaixo da cama.

Menino: Vixe! É agora que me pegam aqui!

Narrador: Foi então que viu aparecer um pássaro que mergulhou em uma bacia cheia d'água e se transformou em um príncipe.

Menino: Eu to maluco?! Não é possível! Esse pássaro virou gente! Olha só!

Narrador: O príncipe pegou três objetos de dentro de uma gaveta e disse serem os objetos de sua amada. Dormiu e no dia seguinte voltou a ser pássaro e saiu voando pela janela. O menino aproveitou para escapar do palácio e foi logo contar tudo o que viu para a princesa. Quem sabe assim ela volta a se alegrar!

\section{CENA 6}

A cena se passa no quarto da princesa.

Menino: Realeza, veja bem! Foi isso mesmo que eu expliquei. Ele tirou primeiro o espelho, beijou e disse: 
- Esse é o espelho da minha amada.

Pega então o pente, beija e diz:

- Este é o pente de minha amada - e guarda de novo no armário.

Por último, pega a fita, dá-lhe um beijo e diz:

- Esta é a fita de minha amada - e lá vai ela pro armário também.

Princesa: Me conta outra vez.

Menino: Eu sabia que a senhorita ia achar essa história demais. E é tudo verdade!

Princesa: Conta, conta com todos os detalhes.

Menino: Vou contar, foi assim.

No restante da cena aparece o menino falando e a princesa vai se animando, toma um prato de sopa, até que ele se levanta para sair.

Princesa: Combinado então! Amanhã eu vou até a floresta te encontrar, você me mostra o caminho e depois disso some desse reino com o que eu vou te dar. Não conta pra ninguém que me levou até lá.

Menino: Combinado realeza!

CENA 7

A cena se passa no quarto do príncipe. A princesa está debaixo da cama.

Princesa: $\mathrm{Ai}$, meu Deus, eu espero que essa história toda seja verdade e que ele chegue aqui logo.

O pássaro entra e se transforma em príncipe.

Princesa: É ele, só pode ser ele. Não consigo ver mas esse barulho é o de suas asas. É ele mesmo!

Príncipe: Este é o espelho de minha amada. Este é o pente de minha amada Esta é a fita de minha amada.

Princesa: E aqui está a sua amada.

Príncipe: Como? Como você chegou aqui?

Princesa: Cheguei, chegando. Não importa, o que importa é que estou aqui e agora posso entender porque você roubou todas as minhas coisas.

Príncipe: Eu roubei porque te amo e por isso mesmo você deve voltar ao teu palácio.

Princesa: Não! Por que não ficaremos juntos?

Príncipe: Eu sou um pássaro durante o dia e não tenho como deixar de ser.

Princesa: Como?

Príncipe: Eu sofri uma maldição e desde então tenho vivido como pássaro durante o dia e homem durante as noites e a única maneira desse encantamento passar seria que a mulher que eu amo e que me ame passasse 7 anos em um nicho a pão e água. Por isso você deve voltar, eu serei pássaro o resto de minha vida.

Princesa: $O$ que são sete anos se pensarmos na vida toda que teremos pela frente? Eu ficarei estes anos no nicho para livra-lo da maldição.

Príncipe: Não, nem pensar! É muito sofrimento.

Princesa: Menor do que te perder prá sempre. 


\section{CENA 8}

Princesa no nicho. A princesa fica parada enquanto outras mulheres vão fazendo serviços de casa de forma repetida, várias vezes, tornando visível o passar do tempo. Entra o príncipe e abre a porta do nicho.Princesa cai no chão.

Príncipe: Bah! A que você se reduziu pelo meu amor. Agora não te quero mais.

O príncipe sai e a deixa só, ela vai se rastejando e depois andando até a rua e senta no meio fio, chorando.

\section{CENA 9}

A cena se passa na rua do reino.

Princesa: Como pode ser?

Velha: O que te aconteceu, moça?

Princesa: Ai! Eu não sei nem como explicar!

Velha: Começa do começo.

Princesa: Eu fiz quinze anos e ganhei um presente lindo do meu pai.

Velha: Calma, tá tudo bem. Bom, ao menos vai ficar, você verá.

Princesa: Veio um pássaro e roubou meu presente e roubou o segundo e o terceiro. Eu fiquei muito triste, sem entender porque aquele pássaro me roubava todos os presentes.

Velha: E então?

Princesa: Então eu descobri que ele era um príncipe que me amava, o príncipe daquele castelo ali.

Velha: Um príncipe?

Princesa: É estranho, eu sei. Mas ele tinha um feitiço e para ficar perto de mim, como era pássaro durante o dia, roubava meus presentes.

Velha: Entendi. E o que aconteceu depois?

Princesa: Eu resolvi ficar sete anos no nicho pois só assim ele voltaria a ser homem e poderíamos nos casar.

Velha: Uma grande prova de amor.

Princesa: Eu achei que ele merecia e me amava e fosse me esperar... Mas hoje foi o último dia e ao abrir a porta do nicho e me ver assim, ele disse que não me quer mais! Velha: Não te quer mais? Por que?

Princesa: Não sei! Pelo que me transformei, foi o que ele me disse. Nisso você se transformou pelo meu amor, agora não te quero mais! No que me transformei? 
Velha: Você se transformou em uma mulher mais forte e agora preste atenção. Pegue essa bolsa e daí você poderá tirar todo o dinheiro que necessite, que ele nunca acabará. Gaste tudo o que precisar que aí você terá a bolsa sempre cheia.

Princesa: Posso gastar tudo o que precisar?

Velha: Pode.

\section{CENA 10}

Narrador: A princesa ficou boa novamente e se recuperou daqueles anos todos no nicho. Foi então construído um palácio em frente ao palácio do príncipe. Ele ficou muito intrigado sobre quem estava construindo um palácio tão lindo e muito curioso para ver quer seria o morador daquele local. No primeiro dia que viu a nova moradora ficou fascinado por ela. Os dias foram passando e o príncipe cada vez mais apaixonado. Tentava falar com ela e ela batia a janela em sua cara, deixando-o com as palavras na ponta da língua.

\section{CENA 11}

A cena se passa na sala do palácio do príncipe. Ele está olhando pela janela a procura da princesa. São 3 horas da madrugada.

Príncipe: Tem que ter um momento que ela apareça. Por que será que me vira a cara todas as vezes? Não saberá que eu sou o príncipe deste reino?

Entra o Rei.

Rei: Mas o que você ta fazendo aqui a estas horas?

Príncipe: Estou esperando para ver se ela aparece. Quem sabe ela não quer que ninguém veja nós dois conversando.

Rei: Meu filho, você ta louco? Vai dormir.

Príncipe: Ah, meu pai! Acho que estou ficando louco por essa mulher.

Rei: Mas por que ela? Tem tanta moça boa, bonita e louca de amor por você!

Príncipe: Que importa, pai? Já sei!

Rei: Vai fazer uma viajem por outros reinos e encontrar a tua princesa!

Príncipe: Não! Vou pedi-la em casamento! Isto é, o senhor em meu nome, como deve ser.

Rei: Como?

Príncipe: Está claro pai, não é que ela não me ame, é que não quer comentários sem que a gente esteja comprometido.

Rei: Você acha? Eu duvido.

Príncipe: Pai, vai lá, por favor. Pede a mão dela em casamento e então eu serei o homem mais feliz do mundo.

Rei: E voltará a dormir e fazer algo mais que olhar por essa janela?

Príncipe: Vou fazer tudo o mais para que ela veja com que homem ela vai se casar.

Rei: Eu não sei não...

Príncipe: Por favor!!! 
Rei: Está bem, tudo pra que você saia desta janela.

Príncipe: Sairei, saio agora mesmo só por saber que amanhã ela poderá me receber e começaremos a tratar de nosso casamento.

\section{CENA 12}

No decorrer da narração, os narradores vão montando a ponte de cristal.

Narrador: Ah, por essa o príncipe não esperava! Ela não aceitou! Ele ficou arrasado e mais alguns dias na janela, buscando-a com os olhos pra tentar entender o que se passava e explicar que a amava. Teria ela desconfiado de sua falta de amor? Mas ele a amava tanto, tanto, que conseguiu convencer o rei a voltar lá.

Narrador 2: O rei voltou, mesmo depois dela ter deixado ele plantado por 3 horas de espera?

Narrador: Voltou! O Rei achou aquilo tudo um absurdo mas voltou porque não agüentava mais ver o filho naquela janela a busca de seu amor.

Narrador 2: E foi então que ela aceitou com a condição da ponte de cristal? Que pedido tão especial! Construir uma ponte de cristal entre os dois palácios para ser por onde ela passará no momento do casamento!

Narrador: Vai ser uma festa e tanto!

Narrador 2: Ô se vai! Ainda mais com essa ponte no meio dos dois palácios e pétalas caindo sobre ela no momento que passar pela ponte. Ah! Todo o povo poderá ver a chegada dela ao palácio dele.

Narrador: Todos nós veremos. Vamos! Já está na hora, em poucos minutos a princesa chegará.

Narrador 2: O príncipe já deve estar a sua espera.

Entra o Príncipe.

Príncipe: Finalmente!

Entra o Rei. Aos poucos vai entrando o povo.

Rei: Está tudo preparado, agora só falta ela!

Príncipe: Ela deve estar chegando, já está na hora!

Rei: Já passa da hora!

Príncipe: É ela ali?

Rei: De tanto olhar para esse palácio você vê gente onde não tem!

Príncipe: Pensei que fosse.

Rei: Não é mas deveria ser! Por que tanta demora?

Príncipe: Agora é.

Princesa começa a caminhar pela ponte, as virgens jogam pétalas de rosas. Pára no meio do caminho.

Princesa: Ah! Uma pétala me feriu! Agora não me caso mais! 
Volta para seu palácio.

Príncipe: Não! O que aconteceu? Volta...

Rei: Uma pétala a feriu? E como pode uma pétala ferir alguém?

Príncipe: Nós podemos tratar teu ferimento... E agora? Não se casa mais?

Rei: Venha, meu filho! Dê-se ao respeito. Sai desse chão que eu não te criei pra ficar se rastejando por ninguém.

Príncipe: Mas, por uma pétala ela não quer mais se casar! Não entendo!

Rei: Vamos, vamos embora. Já!

Príncipe: Por que ela tá fazendo isso comigo?

Saem todos de cena.

\section{CENA 13}

A cena se passa no palácio da Princesa. Princesa de costas.

Rei: Veja bem. Eu jamais teria voltado aqui, mas meu filho me pede a cada dia e eu não suporto mais esta insistência!

Princesa: O que o senhor deseja desta vez?

Rei: Desejo pedi-la em casamento pela terceira e última vez! Não entendo como pode ser ferida por uma pétala!

Princesa: E por acaso duvida que minha pele seja mais delicada que uma pétala?

Rei: Não importa o que eu penso sobre você ou tua pele. Meu filho sofre de amor por você. Já não quer mais comer, não se interessa por nada, não sai de seu quarto, dizendo que se não é para estar casado contigo que não vale a pena viver.

Princesa: Pois se é tão grande o seu amor, peço apenas mais uma prova. A condição para que eu me case com ele é de que seja espalhada a notícia de sua doença pelo reino. No dia de nosso casamento, que se dobrem os sinos por sua morte, seja feito o cortejo e quando ele estiver no cadafalso, eu chego e nos casamos.

\section{CENA 14}

Narrador: O Rei concordou com tudo! Não porque achasse aquilo razoável mas melhor espalhar uma notícia falsa da morte do príncipe do que verdadeira. Fazer aquele casamento era sua última esperança em voltar a ver seu filho recuperado daquela tristeza que parecia não te mais fim. O Rei já havia tentado qualquer outra coisa mas a única solução foi marcar o casamento e espalhar a notícia da doença do Príncipe.

Chegou então o dia do casamento e todo o reino saiu em cortejo acompanhando o Príncipe em seu caixão. Levaram-no até a igreja e lá ficaram chorando e rezando pela perda de seu Príncipe. 


\section{CENA 15}

A cena se passa na Igreja. Todos em volta do Príncipe. O Rei esperando a chegada da Princesa. Entra a Princesa e se aproxima do caixão.

Princesa: Bah! Nisso você se transformou pelo meu amor. Agora não te quero mais! Princesa se vira para sair.

Príncipe: Espera! É você! Como eu não te reconheci até agora? Por que você me fez sofrer tudo isso?

Princesa: Você acha que foi pouco o que eu sofri? Sete anos naquele nicho prá ser rejeitada?

Príncipe: Você tem toda razão. Me perdoe!

Princesa: Acho que agora já sofremos os dois.

Príncipe: Poderemos enfim viver livres de qualquer maldição. Desta vez sou eu quem peço. Me dá tua mão em casamento?

Princesa dá as mãos para o Príncipe.

\section{CENA 16}

Narrador: Casaram-se e viveram felizes para sempre. 


\section{Apêndice 4}

\section{Jogos para as cenas.}




\section{CENA 1:}

Narração com gesto sustentado.

\section{CENA 2:}

Sentindo o eu com o eu

Dificuldade com pequenos objetos

O que está além (fuga do pássaro)

Envolvimento com o ambiente imediato

Transformando a emoção

Cabo de guerra

Começo e fim com objetos

Sombra

Espelho

Explorar e intensificar

Câmera Lenta

Tensão silenciosa

\section{CENA 3}

Narração com gesto

Conversa entre os dois

Canto

\section{CENA 4}

Dificuldade com pequenos objetos

Conversação com envolvimento

Sem usar as mãos

\section{CENA 5}

Ver a palavra

Câmera lenta (para o menino)

Explorar e intensificar 
CENA 6

Explorar e intensificar

Contando um incidente

Envolvimento com o ambiente imediato

Transformando a emoção

\section{CENA 7}

Começo e fim com objetos

Explorar e intensificar

Sussurro no palco

Contato com os olhos

\section{CENA 8}

Contato com os olhos

Quadro de cena

Câmera lenta

O que está além?

Jogo do espelho

Transformando a emoção

Preso

\section{CENA 9}

Contando um incidente

Modelando o personagem

Transformando a emoção

Explorar e intensificar

\section{CENA 10}

Narração com gestos 


\section{CENA 11}

O que está além?

Explorar e intensificar

Conversação com envolvimento

\section{CENA 12}

Dar e tomar (com um objeto)

Convergir e redividir

Quadro de cena

Orientação $\mathrm{n}^{0} 1$

Explorar e intensificar - (para o príncipe)

\section{CENA 13}

Exercício para as costas

\section{CENA 14}

Transformando a emoção

\section{CENA 15}

Contato com os olhos

Tensão silenciosa

Convergir e redividir

Quadro de cena

Partes de um todo

Transformando a emoção

Dar e tomar

\section{CENA 16}

Telefone sem fio

Canto 


\section{Bibliografia}

ALVES, Amara C. A Brincadeira Prometida... O Jogo Teatral e os Folhetos Populares. Dissertação de Mestrado apresentada na ECA_USP, São Paulo,1992.

ALVES, Maria Marcelita Pereira. Do épico ao dramático: uma transposição de códigos. Um estudo sobre problemas de adaptação teatral. Tese de doutorado apresentada na ECA-USP. São Paulo, 1992.

ALVES, Rubem. Conversas com quem gosta de ensinar. São Paulo: Cortez, 1993.

ARISTÓTELES. Poética. São Paulo: Ars Poetica.

ARROYO, Miguel. Ofício de mestre. Petrópolis: Vozes, 2000.

BARBA, Eugenio. La via del Refús - Estudis Escènics - $n^{\circ} 27$. Barcelona: Institut del Teatre, 1985.

A canoa de papel. São Paulo: Ed. Hucitec,1994.

BENJAMIN, Walter. O Narrador in "Obras escolhidas: Magia e Técnica, Arte e Política", São Paulo: Ed. Brasiliense, 1985.

BETTELHEIM, Bruno. A Psicanálise dos contos de fadas. Rio de Janeiro: Paz e Terra, 1980.

BRASIL. Secretaria de Educação Fundamental. Parâmetros curriculares nacionais. Brasília: MEC/SEF, 1997.

BRECHT, Bertolt. Teatro Dialético. Rio de Janeiro: Civilização Brasileira,1967.

Poemas 1913 - 1956. São Paulo: Brasiliense, 1990.

Estudos sobre teatro. São Paulo: Nova Fronteira, 1978.

BUSQUETES, Maria Dolores e outros. Temas transversais - Bases para uma formação Integral. São Paulo: Ática.

CABRAL, Beatriz. (org.) Ensino do teatro: experiências interculturais. Florianópolis: (s.n.), 1999. (Florianópolis: Imprensa Universitária)

CALVINO, Ítalo. Fábulas italianas:coletadas na tradição popular durante os últimos cem anos e transcrita a partir de diferentes dialetos. São Paulo: Companhia das Letras, 1992.

Fiabe Italiane: raccolte dalla tradizione popolare durante gli ultimi cento anni e transcritte in língua daí vari dialetti. Milano:Editore Oscar Mondadori, 1993.

CANTON, Kátia. E o príncipe dançou... O conto de Fadas, da Tradição Oral à Dança Contemporânea. São Paulo: Ática, 1994.

CARVALHO, Marilda B. Coro: Janela para o Mundo. Dissertação de Mestrado apresentada na ECA-USP, São Paulo, 1993.

CASCUDO, Luis da Câmara. Literatura oral no Brasil. $3^{a}$ ed. Belo Horizonte: Ed. Itatiaia; São Paulo: EDUSP, 1984.

Contos Tradicionais do Brasil $8^{a}$ ed. São Paulo: Global, 2000.

História dos nossos gestos Belo Horizonte: Ed. Itatiaia; São Paulo: EDUSP, 1987.

CHACRA, Sandra. Natureza e sentido da improvisação teatral. São Paulo: Perspectiva, 1983.

COELHO, Anna Flora C. A Introducãa do texto literário ou dramático no jogo teatral com crianças. Dissertação de Mestrado apresentada na ECA - USP, São Paulo, 1989.

COELHO, Nelly Novaes. O Conto de fadas. São Paulo: Ed. Ática, 1987. 
CORTELLA, Mario Sérgio. A escola e o conhecimento - fundamentos epistemológicos e políticos. São Paulo: Cortez/Instituto Paulo Freire, 1998.

COURTNEY, Richard. Jogo, Teatro e Pensamento. São Paulo: Perspectiva, 1980.

DELORS, Jacques et. Alii. Educação - um tesouro a descobrir. Relatório UNESCO.

São Paulo:Cortez, 1998.

DIECKMANN, Hans. Contos de fadas vividos. São Paulo: Paulinas, 1986.

DUARTE JR., Jõao-Francisco. Por que Arte Educação? São Paulo: Papirus, 1985.

FERRAZ e FUSARI, Maria Heloísa C. de T. e Maria F. de Rezende. Arte na Educação Escolar. São Paulo: Cortez,1982.

Metodologia do Ensino de Arte. São Paulo: Cortez.

FISCHER, Ernst. 1977. A Necessidade da Arte. São Paulo: Zahar, 1993.

FRANZ, Marie Louise von. A Interpretação dos contos de fadas. Rio de Janeiro: Ed. Achiamé, 1981.

A Sombra e o mal nos contos de fada. São Paulo: Ed. Paulinas, 1985.

FREIRE, Madalena Weffort. A paixão de conhecer o mundo. Rio de Janeiro: Paz e Terra, 1983.

FREIRE, Paulo. A educação como prática de liberdade. Rio de Janeiro: Paz e Terra.

Pedagogia da Autonomia - Saberes Necessários à Prática Educativa. São Paulo: Paz e Terra, 1997.

FURTH, Hans G. Piaget na Sala de Aula. Rio de Janeiro: Forense-Universitária, 1986. GALEANO, Eduardo. De pernas pro ar - a escola do mundo ao avesso. Rio de Janeiro: L\&PM, 1999.

GAMA, Joaquim C. M. Produto Teatral: A Velha-nova História - Experimento com alunos do ensino médio. Dissertação de Mestrado apresentada na ECA-USP, São Paulo, 2000.

HIRSCH, Linei. Transcrição teatral: da narrativa literária ao palco. Dissertação de Mestrado apresentada na ECA-USP, São Paulo, 1988.

KOUDELA, Ingrid Dormien. . Jogos Teatrais. São Paulo: Perspectiva, 1990. Brecht: um jogo de aprendizagem. São Paulo: Perspectiva, 1991. Um vôo brechtiano: teoria e prática da peça didática. São Paulo:

Perspectiva,1992.

Texto e Jogo: uma didática brechtiana. São Paulo: Perspectiva,1996. Brecht na pós-modernidade. São Paulo: Perspectiva, 2002.

LABAN, Rudolf. Domínio do movimento. São Paulo: Summus, 1978.

LANGER, Susane K. Sentimento e forma. São Paulo: Perspectiva, 1980.

LIMA, Meylí Moraes de Oliveira. Um conto e muitas histórias: um trabalho de arteeducação. Dissertação de mestrado apresentada à FE - USP. São Paulo, 1996.

MACHADO, Ana Maria. Texturas: sobre leituras e escritos. Rio de Janeiro: Nova Fronteira, 2001.

MACHADO, Regina. Arte Educação e o Conto de Tradição Oral: Elementos para uma Pedagogia do Imaginário", tese de doutoramento pela ECA / USP, São Paulo, 1989.

MAGALDI, Sábato. Panorama do Teatro Brasileiro. São Paulo: Global, 1997.

MAGALHÃES, Basílio de. O Folk-lore no Brasil: com uma coletânea de 81 contos poulares dos quais 75 bahianos. Rio de Janeiro: Livraria Quaresma, 1928.

MANTOVANI, A. Cenografia. São Paulo: Ática, 1989.

MATURANA, Humberto. Emoções e linguagem na educação e na política. Belo 
Horizonte: Editora UFMG, 1998.

OLIVEIRA, Ronaldo A. Arte e Ensino Público - Desvelando uma experiência com o ensino de artes visuais na cidade de Jacareí - Conquistas, Transformações e Limites. Dissertação de mestrado apresentada na Universidade Presbiteriana Mackenzie, São Paulo,2000.

OLIVEIRA, Ulisses Ferraz de. Veredas do estranhamento: pedagogia do teatro e producão de texto. Tese de doutorado apresentada na FE-USP. São Paulo, 2001.

PAIS, Marco Aurélio Vieira. A Aquisição da competência semiótica para a atuação teatral. Dissertação de Mestrado apresentada na ECA-USP, São Paulo, 2000.

PALLOTTINI, Renata. Introdução à Dramaturgia. São Paulo: Brasiliense,1983.

PAVIS, Patrice. Dicionário de teatro. São Paulo: Perspectiva, 1999.

PEIXOTO, Fernando. Teatro em Questão. São Paulo: Hucitec,1989. Brecht - Vida e Obra. São Paulo: Paz e Terra, 1979.

PELLEGRINI F', Américo. Literatura folclórica. São Paulo: Nova Stella: EDUSP, 1986.

PIAGET, Jean. A Formação do símbolo na criança. Rio de janeiro: Guanabara Koogan S.A, 1978.

A Psicologia da Criança. São Paulo: DIFEL, 1982.

O Julgamento Moral na Criança. São Paulo: Mestre Jou, 1977.

PROPP, Vladimir I. Morfologia do Conto Maravilhoso. Rio de Janeiro: Ed. Forense Universitária, 1984.

PUPO, Maria Lúcia de Souza Barros. No reino da desigualdade. São Paulo: Perspectiva, 1981.

. "Palavras em Jogo: Textos Literários e Teatro-educação". Tese apresentada à Escola de Comunicações e Artes da Universidade de São Paulo como requisito parcial para obtenção do título de Livre-docente, 1997.

READ, Herbert. A Educação pela Arte. Lisboa-Portugal: Edições 70,1958.

RIOS, Terezinha Azeredo. Compreender e ensinar: por uma docência da melhor qualidade. São Paulo: Cortez, 2001

RODRIGUES, Neidson. Elogio à educação. São Paulo: Cortez, 1999.

ROMERO, Silvio. Folclore brasileiro: contos Populares do Brasil. Belo Horizonte: Ed. Itatiaia; São Paulo: Ed. Da Universidade de São Paulo, 1985.

ROSENFELD, Anatol. O teatro épico. São Paulo: Perspectiva, 1997. Texto/Contexto. São Paulo: Perspectiva, 1973. Teatro Moderno. São Paulo: Perspectiva, 1977. Prismas do Teatro. São Paulo: Perspectiva, 1993.

SCHLICHER, Susanne. Teatre - Dansa. Barcelona: Institut del Teatre, 1993.

SANTAELLA, Lúcia. Arte \& Cultura. São Paulo: Cortez, 1990.

SLADE, Peter. O Jogo Dramático Infantil. São Paulo: Summus, 1978.

SPOLIN, Viola. Improvisação para o teatro. São Paulo: Perspectiva,1987.

O jogo teatral no livro do diretor. São Paulo: Perspectiva, 1990.

STANISLAVSKY, Constantin. A preparação do ator. Rio de Janeiro:Civilização Brasileira, 1982.

A Construção da personagem. Rio de Janeiro: Civilização Brasileira, 1983.

A Criação de um papel. Rio de Janeiro: Civilização Brasileira, 1984.

XIDIEH, Oswaldo Elias. Narrativas Pias Populares. São Paulo: Institutos de Estudos Brasileiros da Universidade de São Paulo, 1967. 